

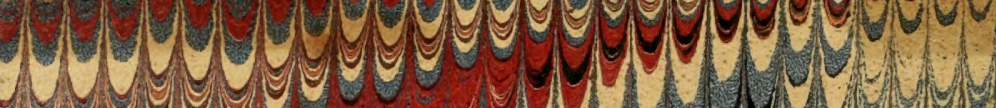

(c)

rowe

\section{(n) gecos}

M

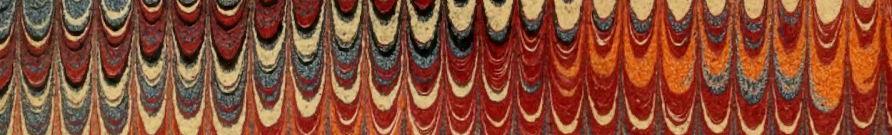

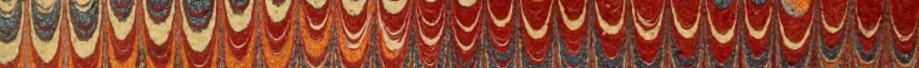

$9 y+3 y^{2}$

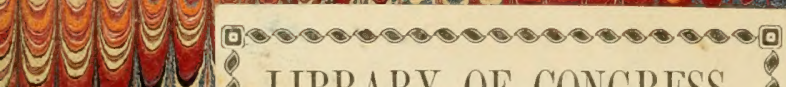

Wy gy

yyys:

y9y:

yy2:

25y:

yyy?

$29 y$ y y yiTED STATES OF AMERIOA. ?

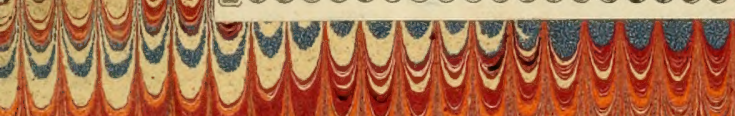

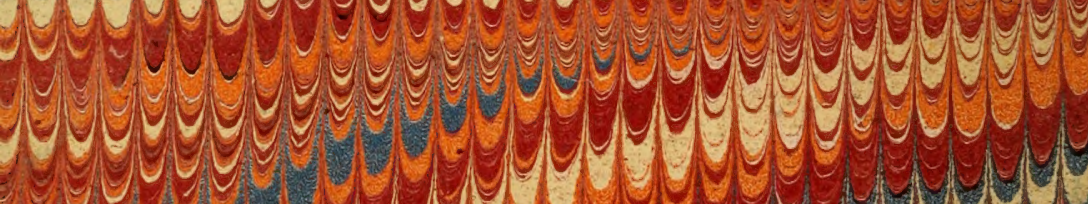

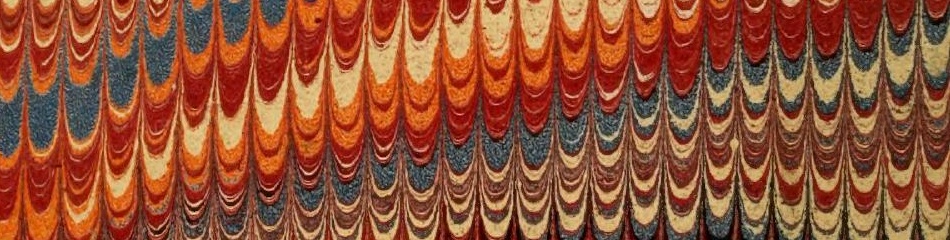

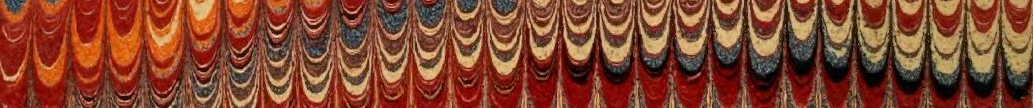

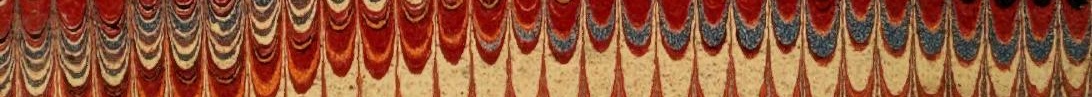

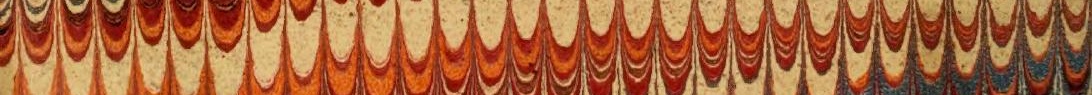
$2004 y$ y g y y 



THE

\title{
AMATEURS’ GUIDE
}

AND

\section{FLOWER-GARDEN DIRECTORY;}

CONTAINING

\author{
EVER REQUISITE DETAIL
}

FOR THE

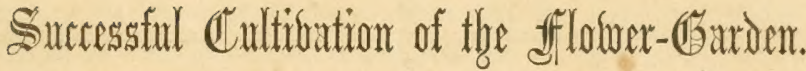

\section{EMBRACING}

THE CLASSIFICATION OF THE BEST VARIETIES OF ROSES, AND ALL PLANTS REQUISITE FOR THE GARDEN, WITH DIRECTIONS FOR THEIR PROPAGATION, AND REMEdiEs FOR THE DESTRUCtion OF INSECTS.

TO WHICH IS ADDED THE

VEGETABLE GARDEN MANUAI.

$$
\text { BY JOHN T. C. CLARK. }
$$

WASHINGTON, D. C.

$$
\begin{array}{r}
\text { Set. } 2^{2} \\
7836 .
\end{array}
$$

PUBLISHED BY TAYLOR \& MAURY.

1856. 
TO THE

AMATEURS OF THE UNITED STATES, THIS VOLUME

Is respectfully dedicated, by

THE AUTHOR.

Entered according to the Act of Congress, in the year 1856, by J 0 H N T. C. CLARK, In the Clerk's Office of the Circuit Court of the District of Columbia.

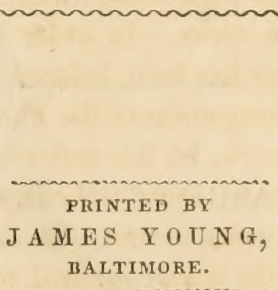




\section{PREFA CE.}

The love of Nature afforts us the purest delight and is implanted in the human breast. While contemplating the wonders of the regetable kingdom, we instinctively low before her shrine and are forced to acknowledge her sovereignty. "Flowers, of all created things, are the most innocent-simple and the most complexplaythings for childhood and oruaments for the grave." Nature is most lavish in her gifts, and in order to appreciate and enjoy them, we should listen to her voice and study well her teachings, for they will surely inculcate a tone of refinement, afford pleasant and healthful employment, and give us exalted views of her Creator.

With a view of being instrumental in indueing some, at least, to partake of the pleasures which the practical study of Floriculture imparts, and to the repeated demands of lind friends, the present little volume is presented to the public.

Namerous and excellent have been the works written on Floriculture, yet they are generally unsuited to the wants of the AmATEUR, for should ho have occasion to consult their pages upon an emergency-being written, in most cases, for the guidance of the scientific Florist-he either cannot understand them or fails to find the information which he seeks. In order to remedy this deficiency, in part, the author has been induced to embody his practical experience in the management of the Flower-Garden; and, in the arrangement of the work, he has endeavored to present, in a clear and available manner, every necessary detail, thereby obviating, or removing to some extent, the difficulties which the Anatevr encounters in the works referred to. Should it be the 
means of assisting one of the numerous Aratecns who have heretofore been deterred from pursuing the practical study of Floriculture to surmount the obstacles which have obstructed his progress, or inducing others to make the acquaintance of FLoms, whose flowery paths abound with innocent pleasures, his object will be fully attained.

With sume few exceptions, the author has cmbodied his own practical experience in the cultivation of the plants enumerated. IIe does not claim all as original, freely acknowledging his ildelutedness to "Loudon's Encrcropadia of Plants" and other standard works, for the generic or specific names of many plants. The practical and valuable information contained in the Vegetable-Garden Manual has been carefully compiled from various reliable sources. He would here tender his acknowledgments to all to whom he is indebted for valuable information.

Under the patronage of the AuATEer the author would respectfully place this his first effort, knowing that their love of the subject on which it treats will enable them to overlook all defficiencies on his part in his endearors to induce others to partake of the enjoyments which Floriculture afford to her votaries. 


\section{N T R O D U C T I ON.}

The practical study of Floriculture imparts to the Asateun innocent and healthful recreation, and opens to him a litrge field for profitable contemplation and study. With what pleasure does he listen to her teachings, and which unfold to his view the beautiful harmony of Nature! All Nature rejoices with him, and the swellings of his owu bosom are but the vibrations of that all-perrading. system of harmony that thrills throughout the vast extent of Creation. Herein are the means for the cultivation of the better feelings of our nature, and which tend to relax the care-worn mind and to raise our affections above the angry turmoils of life.

Nature is most industrious in adorning her domains, and MAN, to whom this bounty is addressed, should obey the lesson. He too should adorn his home-the dwelling of his wife and children-with pleasant objects, and with all those attractions which will make it cheerful. What will tend more to this end than a flower-garden, filled with beautiful flowers, imparting their fragrance, elevating and purifying the soul of the beholder? If this be done, the home will become the abode of eheerfulness.

Where flowers are planted, the home becomes a tasteful residence, while its intrinsic value is greatly enhanced. Cultivated taste gives beauty and value to property, and the small cost of a flower-garden, so far from being a useless expense, as some assert, add to the money-value of the property.

Children learn to love every flower. Innocent, happy childhood, how delighted with the beauties of Flora! In after life, their affections will eling to the beautiful and hallowed spot where 
first they beheld the beauties of Nature, and whose lessons were imprinted on their young hearts by a fond and affectionate mother. The eyes of the father become opened to the influence of the lessous which Nature imparts, and he fondly cherishes every plant which has afforded so much pleasure to his children and comfort to his household. The fond mother anxiously watehes and nurtures them, and finds a solace in the cares, which have a similitude to the trials of earlier days, to soften and soothe, and yet not sadden the heart.

The author would respectfully appeal to all to encourage the study of practical Floriculture, and particularly the Ladies. "A natural fondness for flowers is an evidence of a refined mind, and their cultivation will ereate a delicate taste." Learn to plant and vultivate them, and the pleasure will increase in proportion to your' efforts, and remain when all others have departed. They endear us to local attachments, and the recollection of which, in after years, carry us back to the sunny hours and innocent pleasures of childhood, and afford us delight in risiting the scenes of our youth. 


\section{THE FLOWER-GARDEN。}

\section{THE COMPONENT PARTS OF SOIL,}

Whatever may be their color, are argil, sand, water, and air. Into these original principles may all earths be reduced, however blended with apparently foreign substances. Argil is the soft and unctuous part of the clay. The primitive earths, (argil and sand,) contain each, perhaps in nearly equal degrees, the food of plants, but in their union the purposes of vegetation are most completely answered. The precise quantity of each necessary to make this union perfect, and whether they ought to be equal, it is neither rery easy nor material to ascertain, since that point is best deterunined in practice, when the soil proves to be neither too stiff or adhesive from the superabundance of clay, nor of too Inose or weak a texture from an over quantity of sand in its composition.

\section{BEST SOIL FOR A GARDEN.}

Prefer a sandy loam, not less than twelve inches deep, and good earth, not of a binding nature in summer nor of retentive of water in winter, but of such a texture that it can be worked without diffeulty in any season of the year. Few plants require less depth of earth to grow in to bring them to perfection, and if the soil of the garden be two or more feet deep so much the better; for, when many varieties of plants are in a state of maturity, if their roots be minutely traced, they will be found to penetrate into 
the earth, in search of food, to the depth of two feet or more, provided the nature of the soil will permit them. If avoidable, never make a garden on land whose bottom is of a wet or springy nature. If this precaution be taken, drainage will be unnecessary. When a garden is properly prepared for the growth of plants by trenching, mauuring, and digging, it is brought into such a porus temperament that the rains pass through the soil without being detained longer than necessary. If the soil of the garden be of too strong a nature, it should be well incorporated with sand or the scrapings of gutters, streets, \&c.

\section{PREPARATION OF MANURE.}

The term manure is indiscriminately applied to all substances which are known from experience either to enrich the different soils or contribute in any other way to render them more favorable to vegetation. These may be reduced to light sandy loam from commons, peat-earth from the surface of marshes, vegetable-earth from decayed leares or stalks, sand, lime-rubbish, ashes, snot, stable manure, \&c. There are no known garden plants that will not grow and thrive in one or the other of these earths, alone or mixed. Nurserymen seldom use more than three kinds, riz: Loam, peat, and well-rotted stable manure. With these, they continue to grow thousands of different species of plants in as great or greater perfection as their native countries, and many in a superior manner.

The preparation of composts for general emrichment consists in collecting in the spring each soil in separate heaps, thoroughly mixing them together, and turning them every month until the whole become well incorporated together. After fermentation has taken place they are fit for use and may be applied to the garden. In all composts in which manure is a component part, one year at least should be allowed for decomposition, and what is termed sweetening, before applied to delicate flowers, especially builss. 


\section{PREPARATION OF THE GROUND.}

This important and requisite object is easily aceomplished if the ground is spaded deep and equal and turned over equally with the part which constitutes the surface and well pulverizerl. In many instances these precautions are neglected, the ground being spaled in a shallow manner. When this is the case, the object is only partly attained, for the food of the plants can only be imperfectly procured. Ground should never be spaded in wet weather if avoidable, for sourerness and adhesion then takes place, which is rarely overcome until the operation is again repeated, and which will prove very injurious, if not fatal, to the plants inserted therein. If the grounds need enriching, manure should be applied late in the fall and well dug in,early in the following spring.

\section{SOWING SEED.}

The ground haring been prepared in accordance with the directions above, the beds should be well raked and leveled, and the seed sown in small patches, each kind by itself, or in drills, from an eighth to half an inch in depth, acerding to the size and nature of the seed. Annual flower-seed should be sown in April. May, or June, according to their hardiness.-(See Classification of Plants.) Many flower-seed are planted so deep that they cannot regetate, such as Sweet $A$ lyssum and other small seed, when the Amateur readily concludes that they were old and worthless, and the seedsman is sure to receive nnmerited censure. As $a$ general rule, if the very sualu flower-seed, such as Sweet Alyssum, Portulacea, Petunia, \&c., be sown broadeast, and not eovered, provided the ground has been well pulverized, they will do much better than when sown by the ordinary method. If the seed of the Cypress Vine, Morning Glory, \&c., be soaked in warm wa- 
ter or milk for fifteen or twenty minutes before being planted, they will vegetate much sooner and flower earlier than without. All flower-seed will generally make their appearance in three weeks after being sown. In dry weather, they should have occasional waterings; care should be taken, however, not to give them too much. Excessive moisture is injurious and causes the seed to rot. A small water-pot, having a very fine rose or nozzle, should be used for this purpose.

\section{TRANSPLANTING.}

This operation consists in removing plants, whether from seed, cuttings, or grafts, according to their kinds and other circumstances, to a situation prepared to receive them. Transplanting, therefore, consists of three things, viz:

1. The preparation of the soil to which the plant is to be removed.

The preparation of the soil implies, in all eases, stirring, loosening, mixing, and comminution; and, in many cases, the addition of manure or compost, according to the nature of the soil and the plant to be inserted.

2. The removal of the plant.

The removal of the plant is generally effected by loosening the earth around it and then drawing it out of the soil, in all eases avoiding as much as possible to break, bruise, or otherwise injuring the roots. In the case of small scedling plints, by merely inserting the garden-trowel and raising the portion of earth in which they grow will suffice; but in the removal of larger plants, it may be necessary to dig a trench around the plant. In some cases, the plant may be lifted with a ball of earth containing all its ronts by means of the spade.

3. The insertion of the plant in the prepared soil.

In setting out plants, particularly seedlings, eloudy or rainy wnather should be selected. Seedlings should be set out from 
time to time, lest a hot season should prematurely arrive and destroy them. As a general rule, it will be found advisable to protect scedlings, particularly when first removed from the seed-bed, against the rays of the sun for a few days. An inverted flowerpot will serve for this purpose. With small plants, it will only be vecessary to wake a hole in the soil sufficient to admit the plant, insert the same, drawing up the soil gently around it, and give gentle waterings for a few days, and protect by shading. When chauging the position of large plants, the ground having been selected, excavate with the spade a hole in proportion to the size of the plant to be inserted, and-(if for roses, place broken pieces of flower-pots, soft brick, $\mathrm{fe}$., in the bottom, and cover with soil three inches deep in alternate layers of soil and fragments) - having carefully untangled any matted roots which may present themselves, insert the plant in the hole made to receive it to its original depth, holding the same in an upright position, and work the soil well in among the roots with the hand. Fill in the soil, and gently press with the foot the sides of the plant to keep it in its position. Water and stake securely. Plants should never be crowded, for it is not only very injurious, but destroys the beanty of the garden.

\section{WALKS AND BEDS.}

Great diversity of opinion prevail in regard to the rule or plan on which the grounds should be laid off. Some coutend for straight or parallel walks and beds, while others maintain that the whole beanty of the garden is marred unless it be cut 1 p into serpentine wallis and irregular or fancy-shaped flower-beds. And other's again affirm that in the blendiug of the plants and shrubs togrether, so as to hide all artficial or studied effect, consists the achme of perfection. Where such a difference and taste exist, we would not willingly become the umpirc; but, as erery person will be governed in part, at least, by their own opinion and taste 
in these particulars, we would renture to suggest that, in planning and laying out grounds, if they will cousult " Tun Gexits of Tw Place," and act in accordance with such suggestions as she may point out, they no doubt will be enabled to effect this object to the mutual satisfaction of themselves and their critical friends.

There are, however, two evils under this head to which we would invite the particular attention of the Amateur, and which should be carefully guarded against, viz:

1. In laying off your walks, you cannot be too careful in regard to their width. No walk should be less than two and a half feet wide; for, when contracted, it may prove the deatl of some favorite plant and be the means of raining the dress of some lady friend. If the grouud can be spared, sufficient width should be given to permit the ingress and egress of a wheel-barrow.

2. In order to maintain the uniformity, as well as the durability of garden-walks, it is essentially requisite that a proper drainage should be secured. One inch fall in three feet will be found generally sufficient for this purpose. Where grounds have a greater declivity, not only the walks, but the beds, are likely to wash, which injures the general appearance of the garden. One inch to the foot, from the centre to the edge, will give a form sufficiently rounding for all practical or ormamental purposes in a walk of four feet wide. In walks of greater width, less fall is advisable and will serve the purpose.

\section{GRAVEL-WALKS.}

The bottom should be made with lime-rubbish, pieces of bricks, stones, coal-ashes, or any other hard substance, from four to six inches thick, to keep weenls or grass from growing through. Orer this fine gravel should be laid from three to four inches deep. This should be laid rounding up in the middle, by which means the larger stones will rum off to the siles and may be raked away. It is a common mistake to ling the walks tor rounling, 


\section{AND FLOTVER-GARDEN DIRECTORY.}

which not only make them uneasy to walk upon, but takes off from their apparent breadth. One inch to the fort, is sufficient proportion for the rise in the centre; so that a walk of four feet wide, should be two inches higher in the centre than at the edges, and so in proportion for walks of greater width. One inch in three fect, will give sufficient fall for drainage. These directions are applicahle for medium-sized gardeus. In extcusive grounds, greater width will be necessary, in order to insure the symetrical proportions of the parterre; in which case, the gravel should be laid deeper. As soon as the gravel is laid on, it should be well raked and the large stomes removed. The whole should be well rolled, both lengthwise and crosswise. A clean gravel-walk adds greatly to the beauty of the garden. If the walls are extensive, they should be rolled once a week, particularly after a rain.

\section{GATHERING SEED.}

Those who wish to gather flower-seed must attend to them in the month of August. Many kinils will begin to ripen and should be carefully staked and supported, to prevent them from being shaken by high winds and lost. Others should be defended from dampness, such as Asters, and renerally such as, from the construction of their flowers, are apt to rot and the seed to mould in bad seasons. When they are ripe, they should be gathered and placed in some dry situation, protected against winds, and when dry, rubbed or beat out, placed in papers or boxes, and properly labeled.

\section{PRESERVING SEED.}

When flower-seed are to be preserved longer than the usual period, or when to be sent to a great distance, if placed in cotton, silw-dust, or dry saud, they may be preserved for any reasonable time. 


\section{MANURES FOR HOT-BEDS AND PITS.}

Horse-manure is generally used for forming hot-beds. Bark is only preferable to manure because the substance which undergoes the process of putrid fermentation requires longer time to decay. Hence it is found useful for hot-beds or pits, as it requires to be seldomer moved or renewed than any other substance. Leares, especially those of the oaks, come nearest to bark, and hare the additional advantage that, when perfectly rotten, like manure, they form an excellent compost. Recent stable manure requires to be in ridges or beds a month, and turned orer several times, before it is fit for this purpose. Tan and leares also require a month. Wood-ashes are often mixed with the manures used in hot-beds, and, by some, are supposed to promote the steadiness and duration of their heat, and, at least, to revire it if somewhat decayed. Tan is also used for the same purpose, and, if mixed in proportion of one-third to two of manure, it will form a more durable and less riolent heat than a bed composed wholly of manure.

\section{HOT-BED OR PIT.}

The hot-bed or pit is an important and necessary appendage to the flower-garden, and should nerer be omitted if room can be spared and an elegihle site obtained. Many tender rarieties of plants can be safely kept in an ordinary pit through the severest winters. Beside enabling the Amateur to save many valuahle plants which would otherwise be lost from the effects of frost, if the spring should prove backward or unfarorable to the sowing of annual flower-seed, this difficulty may be readily overcome by the aid of a small pit, thereby enabling him to be fully prepared to meet any emergency which may present itself. Many plants, 


\section{AND FLOTER-GARDEN DIRECTORY.}

whose propagation in the open ground is attended with difficulty, can be successfully multiplied by the use of the pit or hot-bed. To construct a pit of six feet wide, five feet long, two feet deep at the top, and one foot deep at bottom, double-cased all round, to set six inches in the ground, would cost complete $\$ 15$, and, with ordinary care, would last several years, and in which seventy-five medium-sized plants, in pots from three to six inches each, can be kept as securely, if not in a better condition, than in a green-house; for the heat of the pit, with proper attention, could be kept more regular. In many gardeus, the entire cost would be saved the first season. The pit should have a southern exposure. Tan or saw-dust should be placed between the outer and inner cases, which will keep out the frost. Sifted coal-ashes, in theabscence of manure, should be placed in the bottom to the depth of six inches. In mild weather, the sash should be raised to admit air, but care should be taken to close up the pit on the approach of frost. Water the plants sparingly, and do not give them an over supply, or Jou may have an accumulation of dampness which cannot be casily counteracted, and which, if not removed, will seriously injure the plants. If the greeu-fly should make his appearance in the pit, place a few live coals in a pan at the bottom and a handful of tobacco-leaves orer the same, closing up the pit to keep in the smoke. Let the pit remain closed for one hour, and these troublesome pests will readily be exterminated. After the expiration of an hour, remove the sash and gire air. Fumigation should only be done in clear open weather.

If desirable, the pit can be so constructed that it can be taken apart without injury, in the spring, and housed until is again required in the fall. This can be effected by haring hooks and staples fixed at each corner, at bottom and top, on the inside, (instead of the usual manner of nailing, ) which will hold it securely together. Pits constructed on this plan are frequently resorted to where the grounds are limited. In very cold weather, the sash should be covered with shutters, or some other article, which will keep the frost from them. A roller, made fast at the top of the 
pit and worked by pullies, to which matting or carpet is attached, will serve for this purpose.

\section{GARDEN TOOLS.}

Every well-regulated garlen should be supplied with the following tools, viz: Sivade, shovel, rake, scuffle-hoe, budding and pruning-knife, syringe, snip-shears, garden-trowel, small and large watering-pot, small saw, and hatchet. Where the grounds are exteusive, others will be necessary. Stakes, from one to five fect in length, and of diferent thickness, should always be kept on hand; together with cotton-twist, bass-natting, mails, tacks, and leather, for securing vines and other ruming plants to trelleses, pillars, \&c. Leather should alone be employed for securing vines and other climbing plants, as it is in all respects preferable to twine, for the latter, on becoming wet, shrink and injures the plant.

\section{PRACTICAL DIRECTIONS.}

Neatness and order are always indispensable in a flower-garden, and when not secured, neither the beauty nor variety of the plants will compensate for their abscence. In order to secare these important requisites, the following suggestions should be strictly adhered to, viz:

1. Perform every operation in the proper season and in the best manuer. This is to be acquired in part by practice and partly also by reflection. For example: In spading up a piece of groumrl, it is a common practice with some persons to throw the weeds and stones on the sparded ground, or on the adjoining walk, with the intention of gathering them up afterwards. A better way is to have a wheel-barrow, box, or basket, in which to place the weeds, stones, and other extraweous matter, as they are picked up out of the ground. Some persons, in planting or weeding, throw down all weeds, stones, \&c., with a view to pick them up or rake 
them off together afterwards. It is better to have a basket or box, either common or subulivided, in which to hold in one part the plants to be set out, and in the other the extraneous matter.

2. Complete every part of an operation as jou proceed, and finish one job before beginning another.

3. In leaving off work, always place the tools where you can readily find them when wanted.

4. Keep a vigilant watch for weeds, leaves, or other unsightly objects, and remove them to the compost heap.

5. In removing a plant, be careful to remove at the same time all roots, stems, leaves, or whatever else is of no further use or may appear slovenly.

6. Attend at all times to tools, keeping then clean, sharp, ant in perfect order. See particularly that each is placed in its proprer situation, both in winter and summer, thereby preventing their exposure to dampness and rust, which greatly impair their usefulness.

7. Allow no blanks in box-edgings, beds, rows, \&e., and keep the first cut to the utmost nicety.

8. Keep the shapes of all plants filled with wood according to its kind, and let their training be in the first style of perfection.

9. Keep all walks in perfect form, whether raised or flat, free from weeds, dry, and well rolled.

10. See that all plants are securely staked, to prevent their breakage from an overgrowth of wood or by high winds. If the stakes be painted green, they may partially be hid, and will servo to improve their appearauce and preserve them. If placed on the : outh side of the plant, it will serve in some measure to protect it from the burning rays of the sun.

\section{WATERING GARDENS.}

In general, this is only requisite when plants are first set out, or in very dry seasons. As ailment to plants in a growing state, 
for keeping under insects, and to cleanse the leaves, it may at times, however, become necessary. All watering should be done in the evening, or early in the morning, unless it be confined to the roots. In which case, plants in a growing state may be watered at any time, if the earth be remored from the surface to the depth of four or six inches, and a bowl formed around the plant. Pour the water in the bowl, and as soon as it settles, replace the earth, which will prevent the ground from baking, an is usually the case where the ordinary method is resorted to. When applying water to the tops or leares of plants, the rose of the watering-pot or the syringe should be employed. 


\section{CLASSIF ICA TION.}

Taving described in the preceling pages all the essential particulars, in detail, for choosing soil, sowing and gathering seed, transplanting, and general directions for the mamagement of the flower-garden, we shall endeavor to embrace in the following classification all of the principal plants proper for the garden, with intimations of their uature, growth, and various metherls of propagation, explained under their respective heads, and consisting of -

Tender annuals,
Half-Hardy anNuals,
Hardy anNuals,
Biennials, .

\section{Perennials,}

BULBOUS AND TUBE-ROOTED PLANTS,

DECIDUOUS PLANTS, $\triangle \mathrm{ND}$

Evergreens,

In examining the catalogue of the seedsman, with a view of making a selection of such plants as will afford a proficiency and variety of bloom to the flower-garden, the Amateur becomes confused with the fine botanical names and the indefinite directions given for their culture, and often selects those of inferior merit. In order to assist him in making a judicious selection, we shall cndeavor to give an accurate description of each plant embraced in the following lists, giving both the botanical and common name, time of flowering, colur, and halit of each plint. The time of flowering, hardiness, directions for sowing seed, de., correspond to the meredian of Washington. Due allowance being made for different latitudes, they will be found to be equally applicable. Slight variations may occur in some of these particnlars, owing to position or culivation, but those designated will generally be found to be correct.

Annual flowers. - All plants of this tribe are only of one summer's duration; some of but two or three months. Anuuals may 
be divided into tender, half-hardy, and hardy varicties. The seed of tender annuals, such as the Cypress Vine, Thunbergia, Sensitive Plant, \&c., should be sown about the first of June. The hulf-hardy annuals, such as Balsam, Cockscomb, Marigold, de., should be sown about the middle of May. Hardy annuals, such as Candytuft, Clarkia, \&e., may be sown in April or May. If sown, however, early in the autumn, they will grow large enough for transplanting early in the spring, if slightly protected through the winter. By this method, they will produce their flowers much earlier.

Bienaral flowers. - These are principally of two years' duration, at least in their continuance in good perfection, being raised from seed sown in the spring for flowering the year following. In some varieties they most wholly decay, top and root; and, in others, although they continue longer, generally become of a weak and straggling growth, and do not flower in equal perfection. Some few may be continued in a perennial state by cuttings, layers, \&c.

Perennial flowers. - The plants of this class are of several or many years' continuance in the same roots, and consist of fibrous, fleshy, and in some tube-rooted kinds. Many sorts are raised from seed, but generally from slips, suckers, layers, and cuttings. They are very oramental and handsome flowering plants, shooting up their flower-stems in the spring, flowering in their proper season, and loosing their tops, wholly or in part, in autumn; and, the roots continuing, flower in that order aunually. The roots of the herbaceous (fibrous) varieties should be divided in the spring. Some kinds may be divided in August, after flowering, when the roots will make fine plants and flower strongly the ensuing year. Suckers should be taken up when the plant is begining to grow. Layers, cuttings, and seed of this class of plants may be grown successfully by the methods deseribed under their respective heads.

Buldous and tUbe-ROOTED Flomers. - These bloom at intervals during the spriug, summer, and fall, and being distinct in char- 


\section{AND FLOWER-GARDEN DIRECTORY.}

acter and beautiful in appearance, add much to the beauty of the garden. They are all perennials in root, which, in the greater part, are bulbous-onion like-either solid, as in tulips and some other sorts, or tumnicated, or of several involving coats, as in the onion and lily; and some sorts are composed of many fleshy scales. The tuberous roots are solid, knobbed, and fleshy, either single or many in a cluster, and in some many smaller tubers connected in a head. All of which are durable or perpetuated in the roots by offsets, and some from seed. They delight in a rich sandy loam. Those requiring support, such as the Tuberose, Dahlia, \&e., should be securely st:ked, to prevent their being broken off by high winds. The depth which each variety should be planted will be found indicated by the figures attached to each in the list, signifying inches, always measuring from the top of the bulb. The summer and fall-flowering roots should be preserved through the winter in dry sand or saw-dust, in a temperature rather under than above what is natural to them. The spring-flowering varieties can be preserved in the same manner through the summer, but, for convenience, they may be kept loose in boxes or papers, free from dampness, till the season of planting. The offsets should be separated when the parent root is taken up. As a general rule, it will be found advisable to plant offsets of all the spring-flowering bulbs as soon as separated; for, if kept long out of the ground, they become exhausted and perish. As soon as the tops have died down, bulbs may be taken up and separated. Hyacinths, Tulips, and Crocuses, will flower much stronger and produce a greater abundance of offsets if taken up every alternate year. Never purchase bulbs which have made much growth before planting, for they are always weakened, and generally will not flower the first season. The spring-flowering varieties should be planted in October and November, and the summer and fall-flowering kinds in May or June.

Deciduods plants. - This class of plants defoliate or shed their leaves in autumn. Their fine foliage and the beauty of their flowers add greatly to the appearance of the garden. They are all 
perennials in root, generally hardy, and may be propagated from cuttings, layers, seed, suckers, and grafting. This highly esteemed family of plants embrace numerous varieties. All diciduous plants should be planted out as early in the spring as the ground will permit, and before the buds begin to swell. They may be planted, however, with some few exceptions, in the fall, after the leaves have fallen. They delight in a rich light loam.

Evergreens.--These are generally employed for ornamental purposes, and comprise many varieties. They are of a hardy nature, retaining their foliage through the winter, making them very desirable. They should be planted out in Narch or April. If carefully taken up with balls of earth, evergreens may be successfully planted in any season of the year, damp and moist weather being selected for that purpose. The plants should be kept out of the ground as short a time as possible. Most varieties of evergreens may be propagated by cuttings, and some from seed. In all seasons, situations, and soils, the plants should have a plentiful supply of water as soon as the earth is filled in around the roots. If this precaution is observed, the soil is carried down by the water, and the erevices about the roots become filled. After the water has settled, care should be taken to have the hole filled up even with the surface of the ground, to prevent the roots from being exposed. Ordinary garden soil will serve for evergreens, but if a rapid growth be desired, it should be moderately enriched with decomposed manure. Mulching is sometimes desirable. 


\section{CATALOGUE OF FLOTVER-SEED.}

The following catalogue embrace such only as have proved to be worthy of cultiration, comprising the best rarieties, either eminently beautiful or fragrant, and such as will give gaiety, brightness, and profusion of bloom to the flower-garden. The first flowering is only designated; many plants continuing to bloom until destroyed by frost.

The The asterisk (*) denotes climbers. † Tender annuals. † Half-hardy annuals. $z$ Hardy annuals. $b$ Biennials. $p$ Perennials.

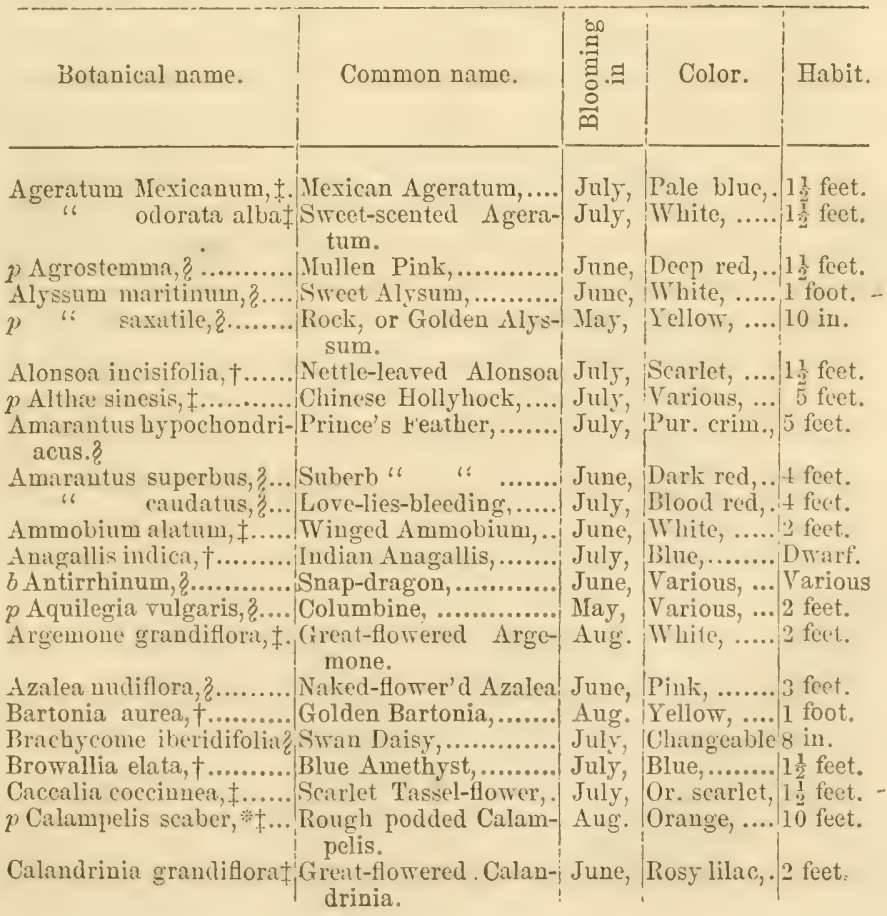


CATALOGUE OF FLOWER-SEED-Continued.

\begin{tabular}{|c|c|c|c|c|}
\hline Botanical name. & Common name. & 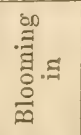 & Color. & Habit. \\
\hline 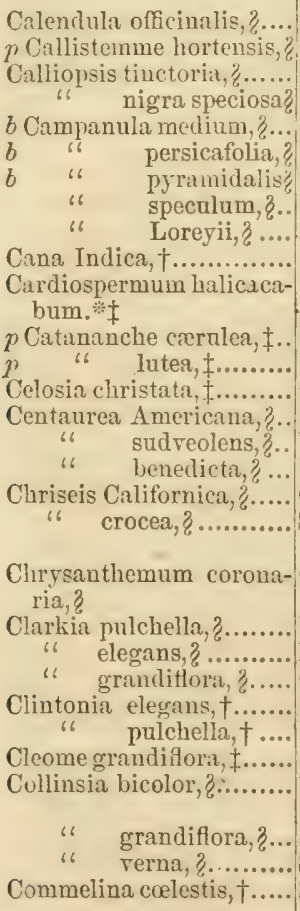 & 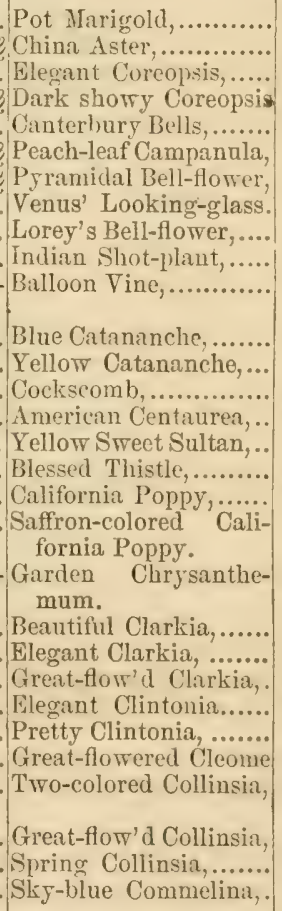 & $\begin{array}{l}\text { July, } \\
\text { Aug. } \\
\text { June, } \\
\text { June, } \\
\text { Augs. } \\
\text { June, } \\
\text { June, } \\
\text { July, } \\
\text { July, } \\
\text { Aug. } \\
\text { July, } \\
\text { July, } \\
\text { July, } \\
\text { June, } \\
\text { Aug. } \\
\text { July, } \\
\text { July, } \\
\text { June, } \\
\text { June, } \\
\text { July, } \\
\text { June, } \\
\text { June, } \\
\text { June, } \\
\text { July, } \\
\text { July, } \\
\text { July, } \\
\text { June, }\end{array}$ & $\begin{array}{l}\text { Deep ora' ge } \\
\text { Various, ... } \\
\text { Yel.\& crim. } \\
\text { Black, .... } \\
\text { Various, ... } \\
\text { Various, ... } \\
\text { Various, ... } \\
\text { Blue, ....... } \\
\text { Blue \&wh'e } \\
\text { Scarlet, .... } \\
\text { White and } \\
\text { green. } \\
\text { Blue,....... } \\
\text { Yellow, ... } \\
\text { Various, ... } \\
\text { Pur. pink,. } \\
\text { Yellow, .... } \\
\text { Yellow, .... } \\
\text { Yellow, .... } \\
\text { Saffron, .... } \\
\text { Various, ... } \\
\text { Light pur.. } \\
\text { Pink, ....... } \\
\text { Rose, ....... } \\
\text { Blue, ........ } \\
\text { Blue, ....... } \\
\text { Pink pur.,. } \\
\text { White and } \\
\text { purple. } \\
\text { Blue \& pur. } \\
\text { Purple, .... } \\
\text { Blue,....... }\end{array}$ & $\begin{array}{l}10 \text { ft. } \\
\text { Varions } \\
21 \text { feet. } \\
2 \frac{1}{2} \text { feet. } \\
21 \text { feet. } \\
3 \text { feet. } \\
6 \text { feet. } \\
1 \text { foot. } \\
\text { Dwarf. } \\
5 \text { feet. } \\
10 \text { feet. } \\
11 \text { feet. } \\
1 \frac{1}{2} \text { feet. } \\
21 \text { feet. } \\
3 \text { feet. } \\
1 \frac{1}{2} \text { feet. } \\
2 \text { feet. } \\
2 \text { feet. } \\
2 \text { feet. } \\
\text { From } 1 \\
\text { to } 4 \text { ft.a } \\
1 \text { foot. } \\
1 \frac{1}{2} \text { feet. } \\
1 \frac{1}{2} \text { feet. } \\
6 \text { inch. } \\
3 \text { inch. } \\
312 \text { ft. } b \\
1 \text { foot. } \\
1 \text { foot. } \\
1 \text { foot. } \\
2 \text { feet. } c\end{array}$ \\
\hline
\end{tabular}

a. The small rarieties possess and interest which is peculiar to themselves, and look more like Daisies or China Asters than Chrysantlemums, embracing various colors, and are perfectly hardy.

b. This plant is rery curious in its structure, as well as beautiful, but its odor is very unpleasant.

$c$. The roots of this plant are tuberous, and may be preserred through the winter in the sime manner as descrilied for the preservation of springfowrering bulis, and will make finer plants than those raised from seed. 


\section{CATALOGUE OF FLOWER-SEED-Continued.}

Botanical name. $\mid$ Common name.

Coreopsis Drammondii,? Drammond's Coreopsis June, Yellow, ....1 foot.

Convolvalus minor,

" major, .... Morning Glory,........ July, Various, ... 12 feet.

“ minoralba,? Dwarf White Morning July, White, .... 1 foot. Glory.

$p$ Chelone barbata, ........ Scarlet Chelone, ...... Crepis barbata, $3 . . . . . . . . .$. Purple-eyed Crepis,....

$p$ Delphinium grandiflo-Great-flotvered Lark-

rum. \&

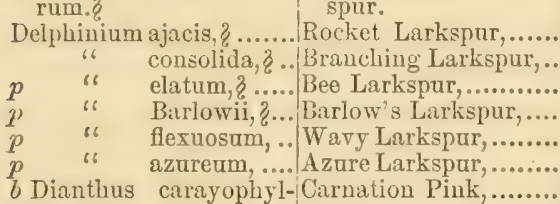
lus. 8

$p$ Dianthus Chinensis,,... Chinese Pink

$p$ " $p$ barbatus, $z$... Sweet William,.........

$p \quad$ " superbus, $\ldots$.... Superb Pink.................

$p$ " plumarius, 3. Feathered, or Pheas-

p ant-eye Pink.

$p$ " alpinus, $\}. . .$. Alpine, or Dwarf Pink, Didiscus crerulea,, ........... Sky-blue Didiscus, ..... $p$ Digitalis purpurea, $\{. .$. Purple Foxglore,....... $p$ " alba,,$\ldots . . . . .$. White Foxglove, ........ $p$ " ochroleuca, $\&$. Great Yellow Foxglove $p$ " lanata,,..... Woolly-flowered Fox-

Dolichos labbab, $*+\ldots . .$. Purple Hyacinth Bean, Erysimum peroffskia- Palestine Mustard,.... num.8

Euphorbia variegata, f... Varigated Euphorbia, Eutoca viscida,,......... Clammy Eutoca,........

".Menziesii,, ........ Menzie's Eutoca,....... p Gaillardia picta, $¥ . . . .$. . Painted Gaillardia,... t" " bicolor, $¥$..... Two-colored Gillardia, Gilia tricolor, $8, . . . . . . . . .$. Three-colored Gilia,... " tenuiflora,,....... Slender-flowered Gilia " capitata, $\%, \ldots . . . . . .$. Headed Gilia

Godetia Lindleyana, ?..... Lindley's Primrose,... July, Orange, .... 3 feet.

\begin{tabular}{|c|c|c|}
\hline 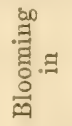 & Color. & Habit. \\
\hline $\begin{array}{l}\text { June, } \\
\text { July, } \\
\text { July, } \\
\text { July, }\end{array}$ & $\begin{array}{l}\text { Yellow, .... } \\
\text { Various, ... } \\
\text { Various, ... } \\
\text { White, ..... }\end{array}$ & $\begin{array}{l}1 \text { foot. } \\
1 \text { foot. } \\
12 \text { feet. } \\
1 \text { foot. }\end{array}$ \\
\hline $\begin{array}{l}\text { July, } \\
\text { July, } \\
\text { July, }\end{array}$ & $\begin{array}{l}\text { Orange, .... } \\
\text { Pale yellow } \\
\text { Various, ... }\end{array}$ & $\begin{array}{l}3 \text { feet. } \\
18 \text { inch. } \\
2 \frac{1}{2} \text { feet. }\end{array}$ \\
\hline
\end{tabular}

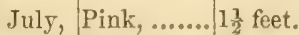
July, Various, ... $2 \frac{1}{2}$ feet. June, Blue,....... 6 feet. June, Blue,....... 4 feet. June, Blue,....... 2 feet. July, Light blue, 4 feet. June, Various, ...2.2. feet.a June, Various, ... Dwarf. May, Various, ... 1 foot. July, White, .... 2 feet. July, White or 6 inch. pink.

July, Varigated,. 4 in. July, Blue,....... 2 feet. June, Purple, .... 3 feet. June, White, .... 3 feet. July, Light yel., 4 feet. July, White and 2 feet. brown.

Jane, Purple, .... 15 feet.

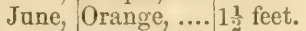
Sept., Varigated, 3 feet. July, Purple, .... 1 foot. July, Blue,........ 1 foot. Aug. Crim. \& yel $1 \frac{1}{2}$ feet. Aug. Crim. \& yel $1 \frac{1}{2}$ feet. June, Varigated, 1 foot. June, Pale rose,.. 2 feet. June, Blue \&wh'e 2 feet. July, Lilac,....... 1 foot.

a. Dianthus._" "The flower of God, or divine flower."-Loudon. 


\section{CATALOGUE OF FLOWER-SEED-Continued.}

\begin{tabular}{|c|c|c|c|c|}
\hline Botanical name. & Common name. & $\begin{array}{l}\stackrel{80}{\Xi} \\
\stackrel{\Xi}{\Xi} . \Xi\end{array}$ & Color. & Ilabit. \\
\hline Godetia rubicunda,, . & Ruddy Primrose,....... & JuIY, & Purple,.. & $1 \frac{1}{2}$ fect. \\
\hline 6 densiflora,?... & Dense-flow'd Primrose & July, & Purple,... & 1 foot. \\
\hline Hibiscus vesicarius, f. & African Hibiscus,...... & June, & Straw,... & 2 feet. \\
\hline$\mu \quad$ " palustris, $8 \ldots$ & Marsh Hibiscus, .......... & July, & Pink, .... & 4 feet. \\
\hline p militarus,,$z \ldots . .$. & Halbert-lea'd Hibiscus, & Aug. & IVhite, .. & 6 feet. \\
\hline $\begin{array}{l}\text { Helichrysum bractea- } \\
\text { tum.? }\end{array}$ & Golden Eternal Flower & July, & Yellow, .... & 2 feet. \\
\hline $\begin{array}{l}\text { IIelichrysum michran- } \\
\text { thum.? }\end{array}$ & $\begin{array}{l}\text { Large Everlasting- } \\
\text { Flower. }\end{array}$ & July, & White, ..... & 2 fect. \\
\hline$b$ Hesperis matronalis, & Dame's Violet,.......... & May, & Various, ... & $1 \frac{1}{2}$ feet. \\
\hline Iberus umbellata,,$\ldots . .$. & Purple Candytuft, . & June, & Purple, ... & 1 foot. \\
\hline "s amara,?,...... & Bitter Candy tuft,... & June, & White, ... & 1. foot. \\
\hline " coronaria, $\%, \ldots$ & Rocket Candytuft,...... & June, & White, ..... & 1 foot. \\
\hline p" "Tenoreina,? ... & Tenore's Candytuft,... & June, & Pale purple & 6 in. \\
\hline $\begin{array}{l}\text { Impatiens balsamina, } \\
\text { Ipomea quomoclit, *t. }\end{array}$ & Double Balsam, ...... & July, & Various,.. & 1 foot. - \\
\hline$b$ is elegans, $3, \ldots \ldots \ldots$ & Tree Cypress, ................ & July, & $\begin{array}{l}\text { scarlet, } \\
\text { Scarlet, }\end{array}$ & $\begin{array}{l}15 \text { feet. } \\
5 \text { feet. }\end{array}$ \\
\hline " coccinea, $*$ *.... & Scarlet Horning Glory & July, & Scarlet, . & 10 feet. \\
\hline Lathyrus odoratus, $* 2 . .$. & Sweet Pea, ................ & Juli, & Various, ... & 5 feet. \\
\hline Lavateria trimestris, $q$.... & Common Lavateria, ... & July, & $\begin{array}{l}\text { White and } \\
\text { pink. }\end{array}$ & 2 feet. \\
\hline $\begin{array}{l}\text { Leptosiphon androssa- } \\
\text { ceus. } 8\end{array}$ & $\begin{array}{l}\text { Androsace-like Leptos } \\
\text { iphon. }\end{array}$ & June, & Varions, ... & 1 foot. \\
\hline $\begin{array}{l}\text { Limnantbus Douglasii, } \& . \\
\text { b Lobelia cartinalis } 3\end{array}$ & Douglas' Limnanthus, & June, & Yel. white, & 1 foot. \\
\hline b) is fulgens, $3 . .$. & Fulgent " "... & July, & $\begin{array}{l}\text { Scarlet, } \\
\text { Scarlet. }\end{array}$ & 3 feet. \\
\hline b " splendens, ?.. & Splendid "6 "6. & July, & Scarlet, . & 3 feet. \\
\hline Loasa lateritia, :........ & Brick-red Lonsa......... & June, & Orange, & 20 fiet.a \\
\hline 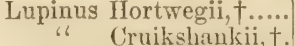 & $\begin{array}{l}\text { Hartweg's Lupin, ...... } \\
\text { Cruikshiunk's Luvin... }\end{array}$ & $\begin{array}{l}\text { July, } \\
\text { July, }\end{array}$ & $\begin{array}{l}\text { Blue, ......... } \\
\text { Shad.white }\end{array}$ & $\begin{array}{l}1 \frac{1}{2} \text { feet. } \\
3 \text { feet. }\end{array}$ \\
\hline 66 hirsutus, †...... & Hairy Lupin, .............. & July, & Blue,........ & 2 feet. \\
\hline Malope granrliflorum, ?... & Grand-flow' M Malope. & June, & liosy crim. & 2 feet. \\
\hline $\begin{array}{r}\text { trinda alba, } 8 . . . \\
\text { Martynea frigrans, }+. . .\end{array}$ & Write Malope, ........... & $\begin{array}{l}\text { June, } \\
\text { Aug. }\end{array}$ & $\begin{array}{l}\text { White, ..... } \\
\text { Rosr lilice. }\end{array}$ & $\begin{array}{l}2 \text { feet. } \\
3 \text { feet. }\end{array}$ \\
\hline i6 lutea, †..... & Yellow & Aug. & Yellow, .... & 3 feet. \\
\hline Mathiola annua, $† \ldots .$. & Ten-week Stock, . & May, & Various & $1 \frac{1}{2}$ feet. \\
\hline $\begin{array}{l}\text { Mesembryanthemum } \\
\text { chrystallinum. } \dagger\end{array}$ & Ice Plant,............ & May, & & Trail'g \\
\hline $\begin{array}{l}\text { Mesembryanthemum } \\
\text { chrystallinum glabrum } \dagger\end{array}$ & Dew Plant,.. & May, & Pink, & Trail'g \\
\hline
\end{tabular}

a. This plant is very curious in its structure. If slightly touched, ejecting a poison, causing a painful blister, which does not pass off for several days. 


\section{CATALOGUE OF FLOWER-SEED-Continued.}

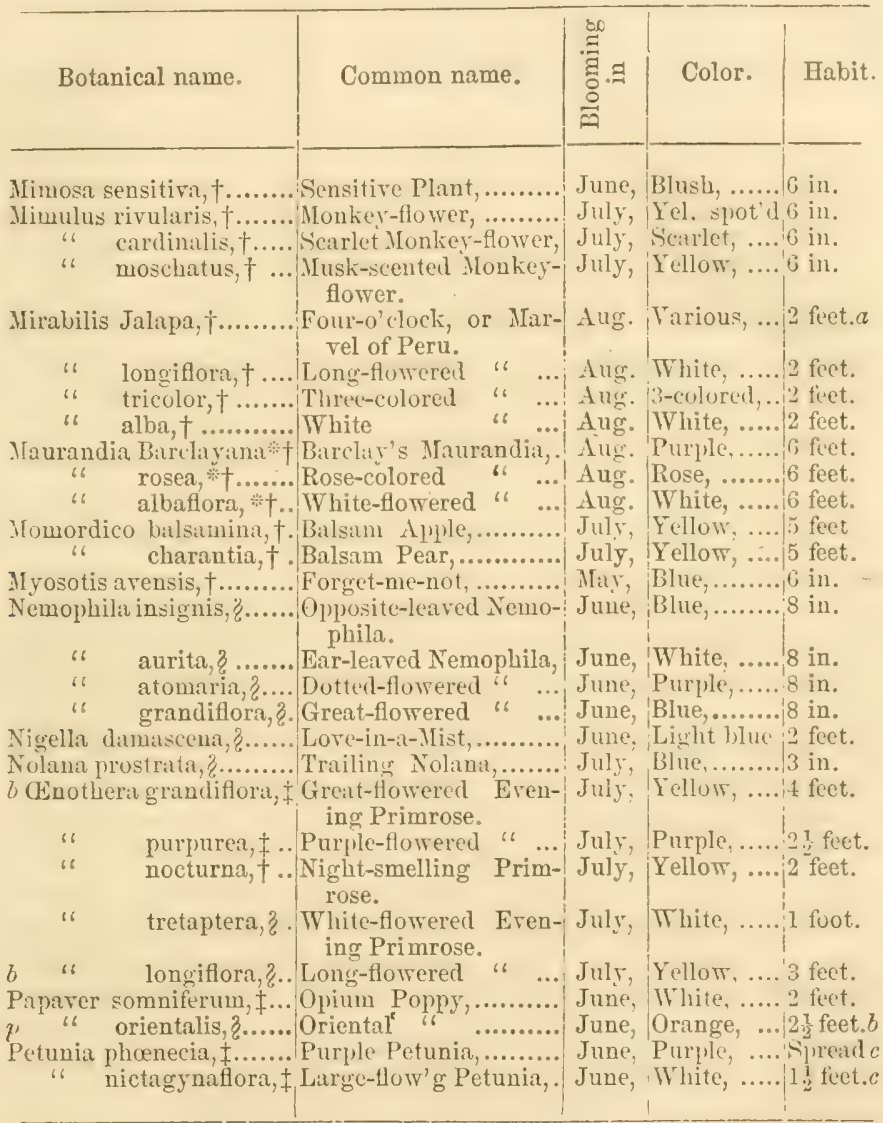

a. If the roots of these plants, though classed as tender anmuls, be taken up and preserved through the winter as described for bulbous roots, they will flower perennially.

b. May be propagated by dividing the roots as soon as the foliage is dead. The plants from seed do not flower until the third year.

c. From these two species have been produced innumerable varieties, all of which can be propagated from cuttings or lajers. Seedlings vary from the mother plant. 


\section{THE AMATEURS' GUIDE}

\section{CATALOGUE OF FLOWER-SEED-Continued.}

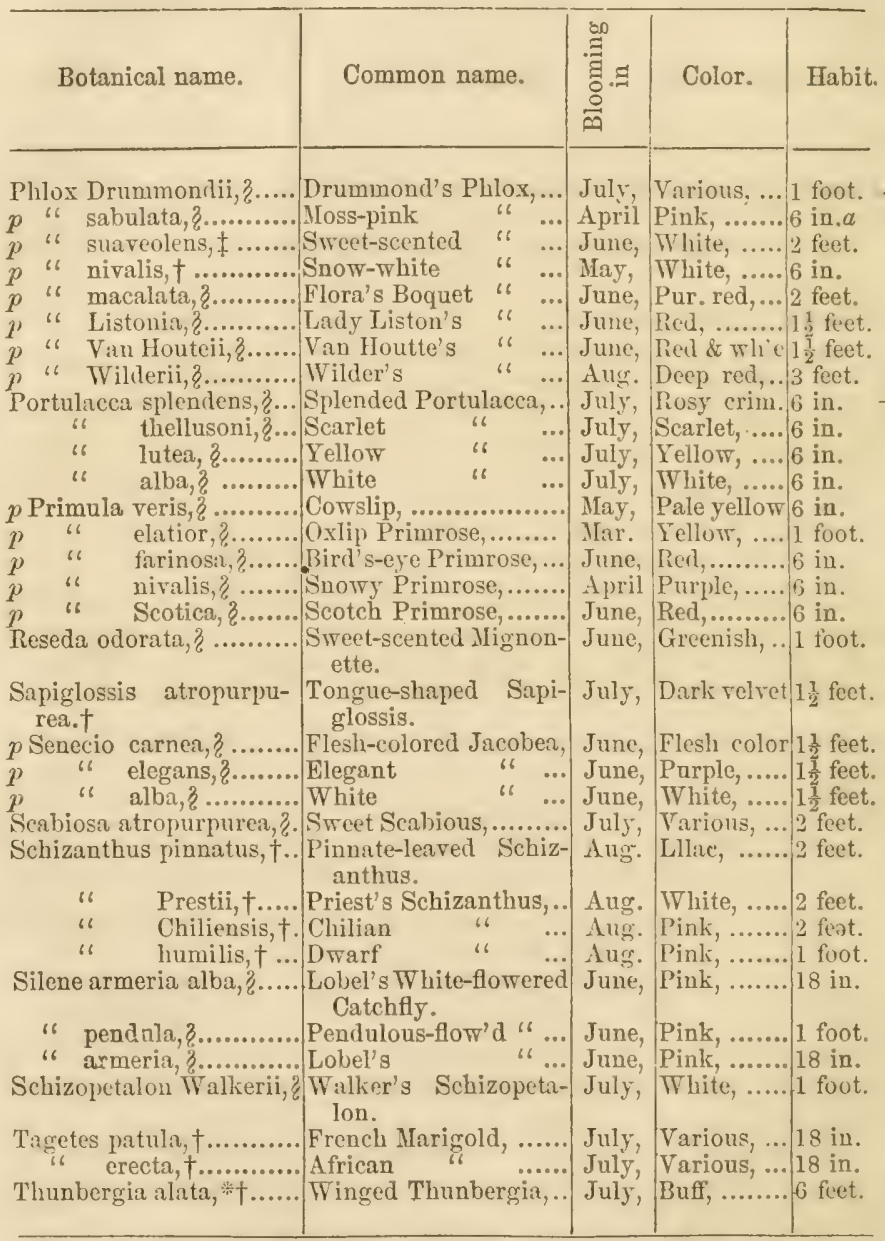

a. Phlox should be shaded when in a frozen state, as the flower-buds are formed in autumn, and are injured by the sun in winter and spring. They may be propagated by dividing the roots after blooming for early floweriug sorts, and in the spring for the late ones, and also from cuttings and seed. 
AND FLOWER-GARDEN DIRECTORY.

CATALOGUE OF FLOWER-SEED-Continued.

\begin{tabular}{|c|c|c|c|c|}
\hline Botanical name. & Common name. & 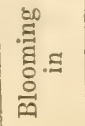 & Color. & Habit. \\
\hline $\begin{array}{l}\text { Thunbergia alata Fry- } \\
\text { erii.*† } \\
\text { Tropicolum peregri- } \\
\text { num.*† } \\
\text { Verbena chamædifolia, },\end{array}$ & $\begin{array}{l}\text { Fryer's Orange-flower- } \\
\text { ed Thunbergia. } \\
\text { Cauary Bird-flower, ... } \\
\text { Germander-leav'd Ver- }\end{array}$ & $\begin{array}{l}\text { July, } \\
\text { July, } \\
\text { May, }\end{array}$ & $\begin{array}{l}\text { Orituges, . } \\
\text { Camary, . } \\
\text { Variouls; . }\end{array}$ & $\left.\right|_{12 \text { feet. }} ^{6 \text { feet. }}$. \\
\hline 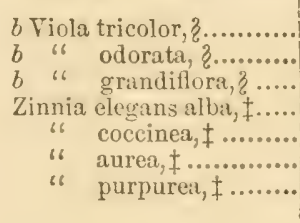 & $\begin{array}{l}\text { Ifeartease, ............. } \\
\text { Sweet-scented Violet,... } \\
\text { Great-flowered } .6 . . . \\
\text { Elegant White Zinnia, } \\
\text { Scarlet Zinnia,......... } \\
\text { Golden " } \\
\text { Purple, ". }\end{array}$ & $\begin{array}{l}\text { April } \\
\text { April } \\
\text { April } \\
\text { July, } \\
\text { July, } \\
\text { July, } \\
\text { July, }\end{array}$ & $\begin{array}{l}\text { Yarious, . } \\
\text { Blue,..... } \\
\text { Tarious, } \\
\text { White, ... } \\
\text { Scarlet, .. } \\
\text { Gold, .... } \\
\text { Purple,... }\end{array}$ & $\begin{array}{l}8 \text { in. } \\
.6 \text { in. } \\
6 \text { in. } \\
2 \text { feet. } \\
2 \text { feet. } \\
2 \text { feet. } \\
2 \text { feet. } \\
\end{array}$ \\
\hline
\end{tabular}

a. From this old and much-esteemed flower have been raised all the present splended varieties, embracing nearly every color. If the plants are covered in October with long manure to the depth of six inches, they may be preserved through the winter. Young plants are preferable. 
BULBOUS AND TUBE-ROOTED FLOWERS.

\begin{tabular}{|c|c|c|c|c|c|}
\hline Botanical name. & Common name. & 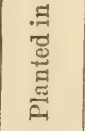 & 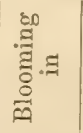 & 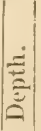 & Color. \\
\hline 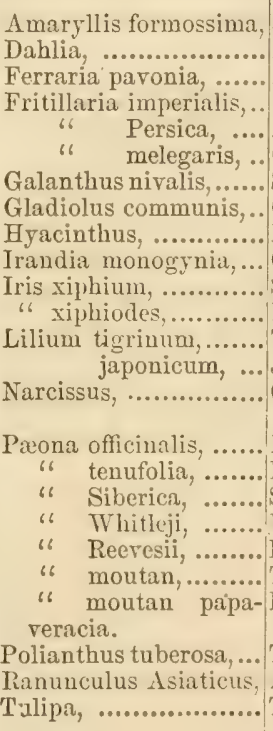 & 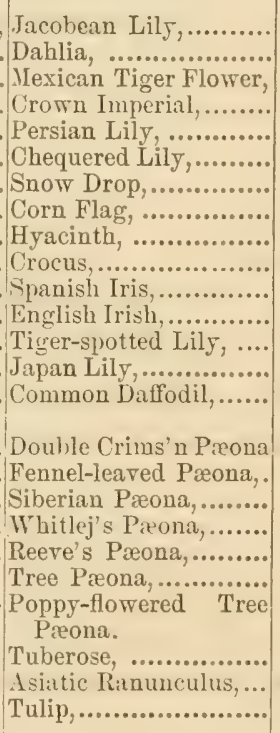 & 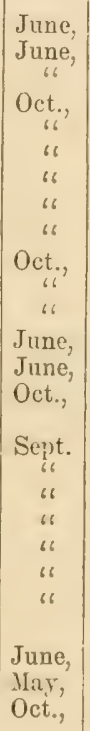 & $\begin{array}{l}\text { July, } \\
\text { Aug. } \\
\text { July, } \\
\text { April } \\
\text { May, } \\
\text { ", } \\
\text { Mar., } \\
\text { July, } \\
\text { April } \\
\text { Mlur., } \\
\text { June, } \\
\text { ". } \\
\text { Aug. } \\
\text { Aug. } \\
\text { April } \\
\text { June, } \\
\text { May, } \\
\text { June, } \\
\text { "6 } \\
\text { "6 } \\
\text { " }\end{array}$ & \begin{tabular}{|l|}
4 \\
2 \\
2 \\
4 \\
4 \\
2 \\
2 \\
3 \\
4 \\
1 \\
3 \\
3 \\
2 \\
2 \\
4 \\
\end{tabular} & $\begin{array}{l}\text { Deep red. } \\
\text { Various. } \\
\text { "6 } \\
\text { Purple. } \\
\text { Various. } \\
\text { White. } \\
\text { Various. } \\
\text { "6 } \\
\text { Various. } \\
\text { "6 } \\
\text { "6 } \\
\text { Orange. } \\
\text { Various. } \\
\text { White and } \\
\text { yellow.a } \\
\text { Orimson. } \\
\text { "6 } b \\
\text { White. } b \\
\text { "6 b } \\
\text { Purple. } b \\
\text { Various.c } \\
\text { White.c }\end{array}$ \\
\hline
\end{tabular}

a. The double variety is better known as "Butter and Eggs." Some species (Jonquille) are various shades of yellow. The scent of some rarieties is said to produce dangerous effects upon the nerves.

b. These maty be propagated by dividing the roots (iu September) into as many pieces as they are tubers with buds.

c. The Tree Preonits can be propagated from sced, suckers, layers, or grafting. Loug manure should be pliced over Paonas in the fall for protection, and which will tend greatly to increase the strength of their bloom. 
DECIDUOUS PLANTS.

\begin{tabular}{|c|c|c|c|c|}
\hline Botanical name. & Common name. & 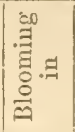 & 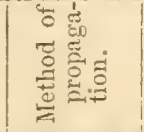 & Color. \\
\hline $\begin{array}{c}\text { Agrostemina plena, ....... } \\
u \text { alba, ....... }\end{array}$ & $\begin{array}{l}\text { Doulble-flowering Rose } \\
\text { Campion. } \\
\text { White-flowering Rose } \\
\text { Campion. }\end{array}$ & June & $\left.\right|_{66} ^{\text {Seed }}$ suckers. & White. \\
\hline $\begin{array}{c}\text { Amygdalus pumila plena } \\
\text { " } \quad \text { persica,....... }\end{array}$ & $\begin{array}{l}\text { Dowhle-flowering Al- } \\
\text { mond. } \\
\text { Double-flower'g Peach }\end{array}$ & April & $\begin{array}{c}\text { Suckers, .. } \\
\text { " }\end{array}$ & $\begin{array}{l}\text { Pink. } \\
\text { 66 }\end{array}$ \\
\hline Anemone Japonica,.... & Japlanese Wind-fluwer. & Sept. & Cuttings, .. & Pur. red. \\
\hline Aristolochia sipho, $\%$.... & $\begin{array}{l}\text { Broat-leared Birth- } \\
\text { wort. }\end{array}$ & July & Cut. \& liny. & . Purplish \\
\hline $\begin{array}{l}\text { Bignonia radicans, *..... } \\
\text { « grandiflora,*. } \\
\text { Calacanthus florida,..... }\end{array}$ & $\begin{array}{l}\text { Searlet trumpliet-flow- } \\
\text { er. } \\
\text { Large-flowered trum- } \\
\text { phet flower. Sweet-scented Shrub. } \\
\text { Sw }\end{array}$ & 16 & $\begin{array}{c}\text { Cuttings, . } \\
\text { " }\end{array}$ & $\begin{array}{l}\text { Scarlet. } \\
\text { Yellow. }\end{array}$ \\
\hline
\end{tabular}

Caprifolium flavum, *..... Yel. trumphet monthly "6 Honeysuckle.

" hirsuta, .... Hairy Honeysuckle,...

Caprifolium periclyme- Woodbine Honessuc- " num.

Caprifolium belgicum. ... Dutch sweet-scented "

Caprifolium belgicum Dutch monthly swect- " menstrus. * scent'd Honeysuckle

Ceanothus Americanus, . New Jersey Tea,........ "

Clethra alnifolia,........... Alder-leared Clethra.. Ang. Bud. \& lay. "

Cydonia. Japonica,.......... Japan Quince Tree..... Iay Cut. \& suck Bril. red.

Cytisus purpurea,.......... Purple-tlowered La- $"$ Cuttings, ... Purple.

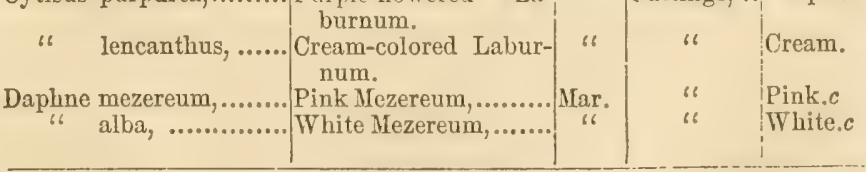

* Denotes climbers.

a. In some catalogues designated "Pipe Vine."

b. "Caprifotium. - A poetical name, signifying goat-leaf; that is to say a leaf which climbs like a goat.-Loudon.

c. Thrives best in a loamy soil, and greatly admired for their friagrnce. 


\section{THE AMA'TEURS' GUIDE}

\section{DECIDUOUS PLANTS-Continued.}

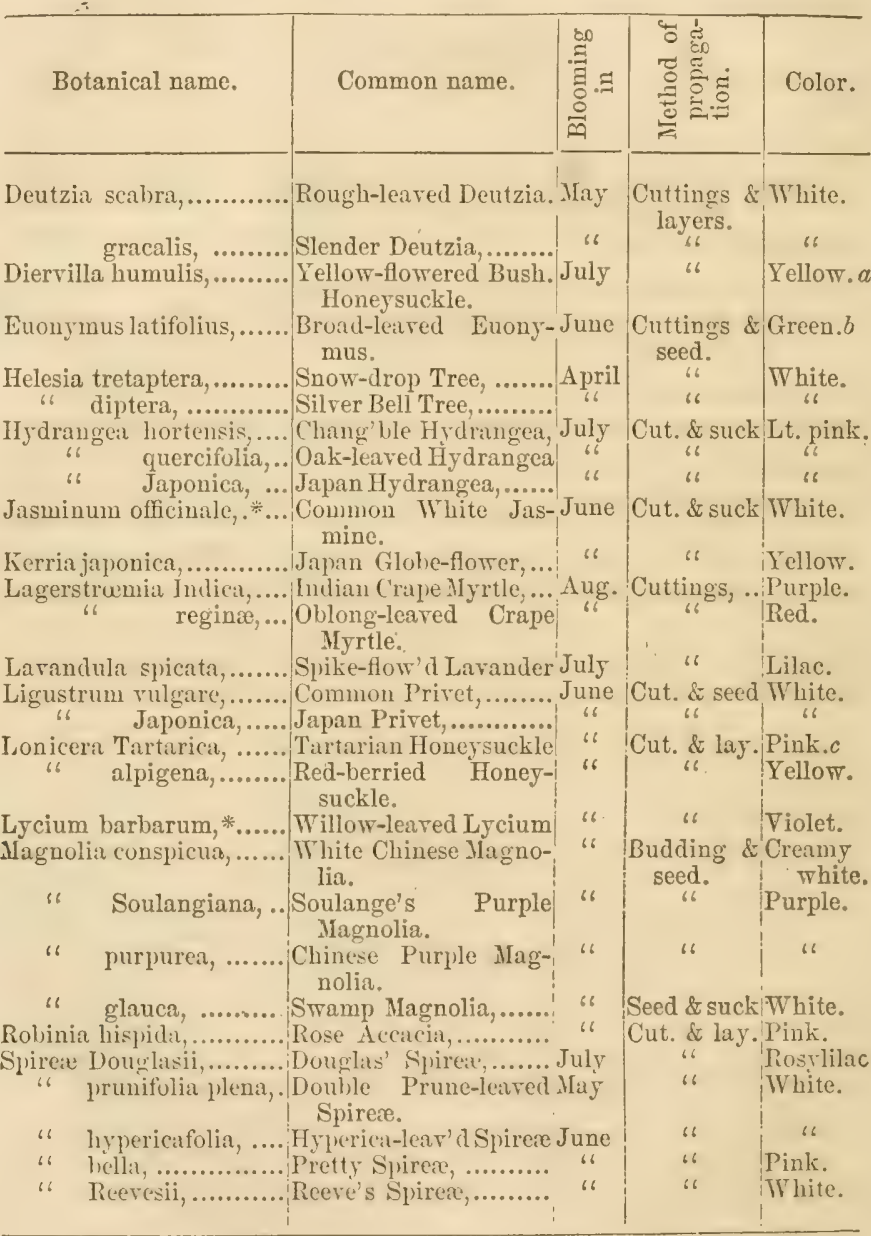

a "Diervilla.-A pretty low shrub."-Loudon.

b. Tery desirathe for their ormamental berries in autumn.

c. "Limiccu.-Comprising the species with a shrubby upright stem, neither climbing or prostrate plints." -Loudon. 
DECIDUOUS PLANTS-Continued.

\begin{tabular}{|c|c|c|c|c|}
\hline Botanical name. & Common name. & 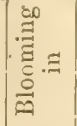 & 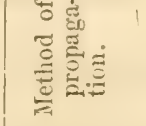 & Color. \\
\hline Symphoria racemosa,.... & Clustered Snowberry, & July & Cut. \& lay. & Pink, $t$ \\
\hline Syringa persica purpurea & P'urple P'ersiau Liluc,. & May & $\begin{array}{c}\text { Cuttings \& } \\
\text { suckers. }\end{array}$ & Purple. \\
\hline " " alba,..... & White Persian Lilac,... & 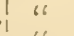 & 6 & White. \\
\hline " $\quad$ vulgaris, .......... & Common Lilac, ........... & 66 & "6 & Lilac. \\
\hline " rosea grandiflora & $\begin{array}{l}\text { Large-flowered Rose } \\
\text { Lilac. }\end{array}$ & 66 & 66 & Rose. \\
\hline $\begin{array}{c}\text { "Chinensis, ........ } \\
\text { Wisteria sinesis, .......... }\end{array}$ & $\begin{array}{l}\text { Chinese Lilac, ............ } \\
\text { Chinese Wistaria, ...... }\end{array}$ & May & Cut. \& lay. & $\begin{array}{l}\text { Violet. } \\
\text { Ist. pur.b }\end{array}$ \\
\hline
\end{tabular}

a. The berries of these plants are very ornamental, remaining after the leaves have fallen.

$b$. Without exception, this is the most magnificient of all deciluous climlscrs. It is perfectly hardy, and if the following treatiment be resorted to, it will flower three times during the season. As soon as the first flowering is over, cut off the young shoots to within three or four eyes of the stem and deprive the plant of its leares, and it will bloom again in August. By repeating the same process as soon as the second flowering is over, the plant will bloom again in October. This treatment does not apply to young plants, but on!y to such as bave become well established. 
EVERGREENS.

\begin{tabular}{|c|c|c|c|c|}
\hline Botanical name. & Common name. & 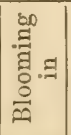 & 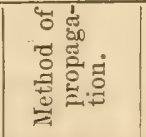 & Color. \\
\hline Abies communis, †..... & Norway Spruce,..... & & Cuttings. & \\
\hline " pulcherrima, †.... & European Silver Fir,... & & .60 & \\
\hline " Douglasii, $† \ldots . . . . .$. & Douglas' Spruce Fir,.. & & 6 & \\
\hline Auracaria imbricata, $† \ldots$ & Chili Pine, & & 6 & \\
\hline Bignonia graudifolia, + & $\begin{array}{l}\text { Large-flowered Trum- } \\
\text { phet-flower. }\end{array}$ & June & 6 & Or. sear. \\
\hline $\begin{array}{c}\text { Buxus suffruticosa,....... } \\
\text { arborescens, }+. . .\end{array}$ & 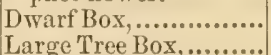 & a.s... & Cut.\& slips. & \\
\hline " myrtifolio,.......... & Intermediate Box,...... & $|\cdots \cdots \cdot|$ & 6 & \\
\hline $\begin{array}{l}\text { Caprifolium sempervi- } \\
\text { rens.t }+\end{array}$ & $\begin{array}{l}\text { Erergr'n Scar. Month- } \\
\text { ly Honeysuckle. }\end{array}$ & June & 66 & Scarlet. \\
\hline Caprifolium flexuosa, $* \dagger$. & $\begin{array}{l}\text { Chinese Twining Hon- } \\
\text { eysuckle. }\end{array}$ & May & Cut. \& lay. & Orange. \\
\hline$" 6$ Japonica, $* \dagger$ & Japan Honeysuckle,... & "6 & 6 & st \\
\hline Cedrus deodar, $† \ldots . . . . . . .$. & Deodar Cedar,........... & .... & Cuttings. & \\
\hline $\begin{array}{cc}\text { Cypressus thoyoides, } † \ldots . . . \\
66 & \text { sempervirens }\end{array}$ & White Cedar,.............. & 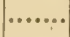 & Cut.\& seed. & \\
\hline "6 sempervirens† & $\begin{array}{l}\text { Common Evergreen } \\
\text { Cypress. }\end{array}$ & & Cuttings. & Tlo \\
\hline $\begin{array}{l}\text { Fypigara repens, ............... } \\
\text { Gelsemium sempervi- }\end{array}$ & Ground Laurel, .......... & April & Slips ......... & Flesh. \\
\hline $\begin{array}{l}\text { Gelsemium sempervi- } \\
\text { rens. } *+\end{array}$ & Evergreen Gelsemium, & June & Cuttings ... & Tellow $a$ \\
\hline 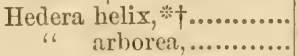 & Common Iry,... & & Cut.\&slips. & \\
\hline « Hibernica, $*$ † ...... & Irish Iry, $\ldots \ldots \ldots \ldots \ldots \ldots$ & & 66 & \\
\hline Ilex latifolia Japonica, ... & $\begin{array}{c}\text { Broad-leaved Japan } \\
\text { Holly. }\end{array}$ & June & Seed... & TVhite. $b$ \\
\hline « opaca,,$\ldots . . . \ldots \ldots \ldots$ & American Holly, & 66 & 66 & 16 \\
\hline " $"$ aquifolium, ........... & English Holly,.......... & 16 & $" 6$ & $" 6$ \\
\hline $\begin{array}{l}\text { " aurea, ................... } \\
\text { Jasminum revolutum, }\end{array}$ & Golden-striped Holly; & 6 & 66 & 6 \\
\hline Jasminum revolutum, *十 & Curled-flow'd Jasmine & June & Cut. \& suck & Tellow. \\
\hline
\end{tabular}

* Denotes climbers.

† Large varieties.

a. A beatiful plant, exquisitely fragrant, aud producing its flowers in great profusion. The juice, as well as the flowers of this pliant, are poisonous. Frequently called the "Carolina Yellow Jasamine."

b. The slowness of growth of the Holly is frequently oljected to. This defect is fully made up in the beutiful scarlet berries which remain on the tree throush the winter. The seed of the Holly do not vegetate till the second yeatr atter being sown. Plants taken from the woods, early in the spring, will be found the best method for securing these beatiful native trees. 
EVERGREENS-Continued.

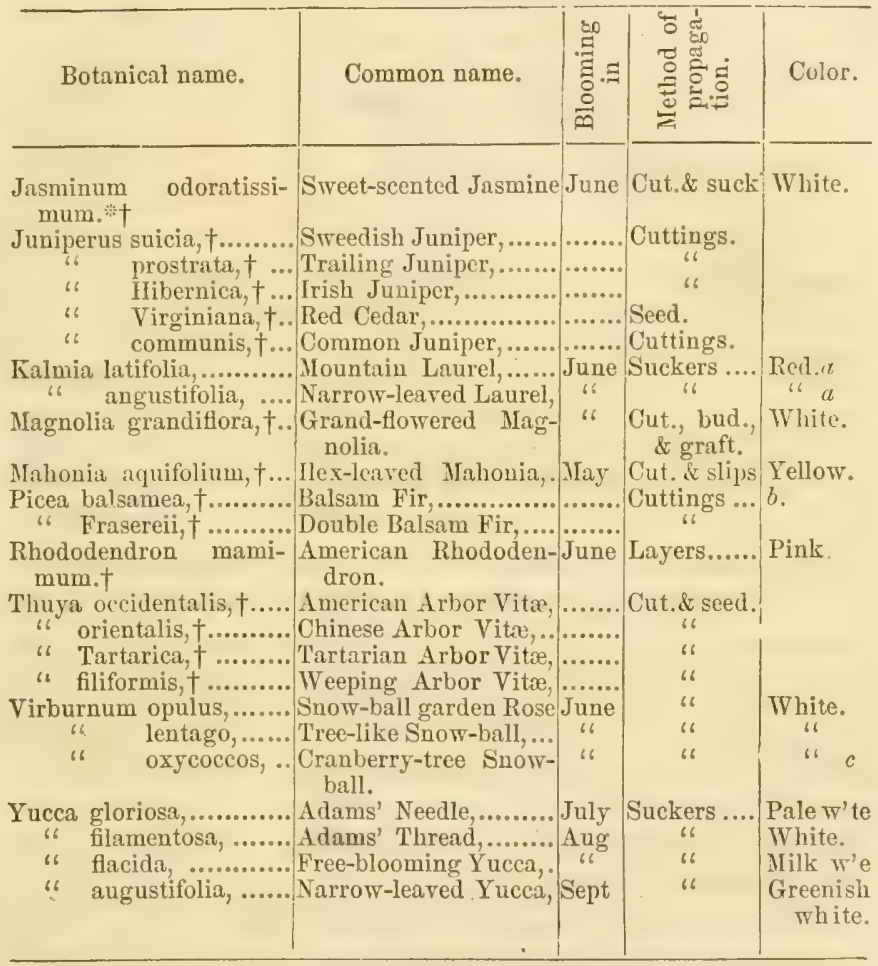

a. These varieties of the Laurel are shrubs of low growth, and are poisonous to animals.

b. Commonly called "Balm of Gilead."

c. This heautiful tree, hearing a fruit of a pleasant acid taste, resembling cranberries, is either in fruit or flower most of the year. 


\section{THE ROSE.}

"The Rose is Nature's moralist-upon its leaf appear

The smile of hope, the blush of love, and sorrow's tender tear.'

This beautiful and farorite flower has justly been denominated the Pride of Flora, and frequently been made the theme of the poet. Language is inadequate to convey a full idea of its delicate tints, enchanting colors, sweet perfume, and harmonious outlines. All Nature seems to have been taxed in its production, and her treasures heavily drawn upon in combining the sweetness and beauty of the Rose. There is no linit to the variety and beauty of her forms and colors. Made the symbol and interpreter of the affections, if her tender and expressive language be blotted out, what a chasm in the language of the heart would be found? The einblemn of purity, the adornment of beauty, and expressive of human affection at the tomb!

In contemplating the raried and heautiful works of Nature, no other flower excites the admiration of the beholder to the same extent as the Rose. How insignificant and imperfect appear the works of man compared to this perfect specimen of Nature's gifts? The mind is elevated in contemplating her grandeur. The profusion and loveliness of her flowers, as displayed in the different vatricties, exalts our conceptions of the wisdom and goodness of the Creator. She expands to Heaven her grateful fragrance and to man her cheerful smiles; and, to snme extent, is the promoter of human joy and the soother of sorrow-fit emhlem of the rictor's triumph, the young bride's blushes, and the tomb. 
In the cultivation of the Rose we experience an exquisite pleasure. It is a sense of the beautiful, - - a faculty of the soul which is awakened. We pereeive in her colors, forms, and älightful odors, the harmony of Nature. "They recall the past and foreshadow the future; and if their fiding hues and seattered petals tell of blighted hope and departed joys of early life, so do their: busting seeds and fresh shoots whisper of a future, which shall restore in fresh beauty and unfading verdue the loved, the cherished, and the lost." Let us then endeavor to carefully preserve, and if possible augment, the number of these sublime and harmonious gifts of Nature, for they largely contribute to the confort of man. The rose should have a place in every garden, and may be propagated from seed, cuttings, budding, grafting, and layering. These various methods will be found described under their respective heads.

\section{GROWING ROSES FROM SEED.}

This is one of the most interesting methods of propagating the Queen of Flora. Each of the other modes, hereinafter described, may excite the admiration of the Amateur, and, when successful, amply reward him for his labor; but, should he be fortunate in a single instance in his experiments in this particular and interesting branch of practical Floriculture, he will be more than compensated for his efforts by the pleasure which he will then enjoy, and be enabled to impart to the admirers of Flora, in beholding the new and beautiful tints which Nature, assisted by Art, has implanted in and around the object of his care and attention.

A large field is here opened to the Amateur, and should the author be instrumental in inducing any to enter it, he trust that they may have their labors rewarded with success, and be enabled to enjoy the same pleasure which he experienced when beholding the success of some of his first experiments in this interesting and beautiful branch of Floriculture. 


\section{IMPREGNATING THE SEED.}

To be successful in this operation, some practice is necessary; but, by careful attention, success will eventually reward the efforts of the operator. Roses have in their centre thready filaments, surrounded by anthers. These, when ripe, contain a yellow dust, the pollen of the plant. This pollen should be applied to the tip of the pistil, which is in the very centre of the flower, when it bursts, and, if the plant should seed, generally impreguates the same to more or less extent. The flower to be operated upon to produce the seed, should be deprived of its anthers early in the morning, with a pair of small cissors. During the day, or the next, with the aid of a fine camel-hair pencil, obtain the pollen from the plant you desire to cross, and apply the same to the pistil of the plant from which you have extracted the anthers. Wet or damp weather is unfavorable to the success of this experiment. In order to insure success, the pollen should be dry and powdery. About the first of November the seed will be matured, and should then be gathered, retained in their capsules, and buried in sand, until the following spring About the first of May ensuing, having prepared the ground, in a shady position, which should be enriched by the addition of well-rotted manure, or leaf-mould, well pulverized, remove the seed from the hips and sow them thinly over the top of the soil. Take a board or spade and press them level on the earth, and cover to the depth of half an inch with sand, leaf-mould, or soil, finely sifted. Givo gentle waterings occasionally with a fine rose. When the plants have made a growth of three or four inches, they may bo removed, by the aid of the garden-trowel, and placed in pots of good rich earth. Place in a shady position, and give gentle waterings. In a few weeks, if the season be not too far advanced, they may be planted out to remain. The bloom of the third year will generally decide the merits of the plant. Many varieties will bloom the first year, and some within the first six months after sowing the seed. 
Some few years since, on the 8th of February, the author planted eight rose-seed, gathered from Semperflonens, (or Sanguinea,) in a box fourteen inches long, ten inches wide, and six inches deep. In the bottom of this box was placed charcoal, well pulverized, one inch deep. Over this, soil composed of well-rotted hog-manure, loam, and leaf-mould, in equal parts, finely sifted, to the depth of four inches, was placed. After leveling the soil, the seed were equally distributed over the top of the same, and covered with sand a quarter of an inch deep, gently sprinkled, and placed in a southern window. At the expiration of five weeks, seven plants made their appearance, and by the 10 th of April following, five rewarded his efforts by showing bloom. The flowers, however, consisted at most of six petals, and all but one were inferior in color to the rose from which the seed were gathered. The pollen was taken from Meldez, (or Thè á Fleurs Jaune.) The second year, this young plant partook largely of the habits of Mellez in the luxuriance of its growth; showing, for a young plant, indications of profuse bloom, fragrance, blush or creany flowers, and beautifully cupped. Unfortunately, the care of this anxiously-matched and nurtured plant devolved on others, who, from excessive moisture, caused it to perish.

\section{PROPAGATION BY CUTTINGS.}

The proper time to take cuttings from the mother plant is when the sap is in full motion, in order that, in returning by the bark, it may form a callus, or protruding ring of granular substance, botween the bark and wood, whence the roots proceed. As this callus, or ring of spongy matter, is generally best formed in ripened wood, the cutting, when taken from the mother plant, should be selected from such wood only as has ripened, and which has always the greatest tendency to produce roots. This is the true principle in the choice of cuttings. They should be made from two to four inches in length, having at least three eyes from 
the lower end, which should he cut off smooth at the bottom, directly under an eye, (as shown in fig. 1,) Insert the cutting in

Fig. 1.

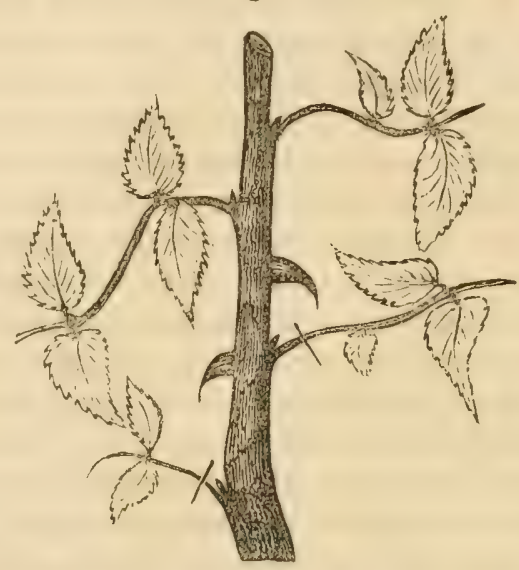

good bank sand or loam, finely sifted, from one to two inches deep, pressing the sand or loam gently around the same with the hand. Place them in a shady position and give gentle sprinklings of water, protecting them from heavy winds. If exposed to the dews, their rooting will be greatly accellerated. In three or four weeks, they will be generally rooted, when they may be removed into pots of good soil, gently watered, and again placed in the shade until they have taken fresh roots. After which, they may be shifted into larger pots for house culture or planted out, according to the pleasure of the grower.

\section{PROPAGATION BY BUDDING.}

Nearly every variety of the rose may be propagated by budding. Some varieties are difficult to manage by the other methods, but, hy budding, readily form handsome plants in one year. Budding consists in taking an eye, or bud, attached to a portion of the bark 


\section{AND FLOWER-GARDEN DIRECTORY.}

of one plant, and generally called a shield, and transplanting it to another. The advantages in bulding is that where a plant is rare, a new plant can generally be had from every eye. This operation may be performed from the beginning of July to the last of August, the criterion being the forming of the buds in axillie of the leaf of the present year. The buds are known to be ready by the shield, or portion of bark to which they are attached, easily parting from the wood. Haring selected such buds as may be required, remove the same, by inserting a sharp thin-bladed knife about half an inch abore the bud and passing the same about one-third of the way through the wood of the shoot, come out again about the same distance below it, making the cut as clean as possible. When the shield is removed it contains a portion of the wood, which should be carefully deprived. By cutting upwards, as shown in fig. 2, the danger of destroying the eye is materially lessened. If the wood be dry, it will not separate easily; in which case it should be thrown aside. Make an incision lengthwise through the bark of the stock, about an inch long, and cross this at the top by another incision, as shown in fig. 3. Raise the bark very carefully, as shown in fig. 4 , and insert the shield within,

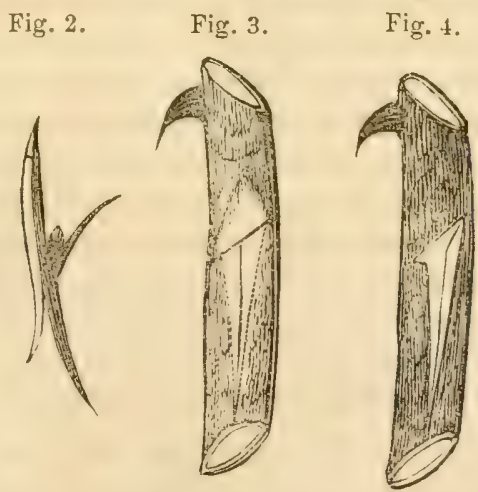

gently pressing it to the bottom of the incision, as shown in fig. 5 . Great care should be taken that it is in close contact with the 
stock. Being satisfied on this point, which is essential to the success of the operation, bind up all except the bud, with either matting, soft twist, or strips of cotton-cloth, (which should be moderately dampened,) as shown in fig. 6. The bud should be left free

Fig. 5.

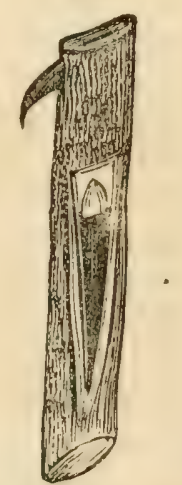

Fig. 6.

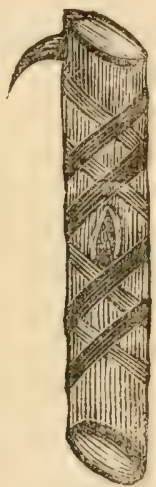

to the air, but protected from the sun or very wet weather, either of which may defeat the object in view. At the expiration of two weeks, the success of the undertaking will be known; and, if successful, in three weeks thereafter, the bandages should be gradually removed, when the stock should be cut off about two inches above the bud, which will tend to strengthen both bud and stock. As soon as the bud commences to make wood, the remaining portion of the stock above the bud should be removed in a neat manner. Care must be taken, however, not to injure the bud, for the least carelessness might remove the same from the stock. All suckers must be removed, otherwise they will divert the sap from the bud, in which ease it must certainly perish. As the bud progresses in growth, it should be supported against high winds. In the fall, cut the plant down to within a foot of where the bud was inserted, which will greatly strengthen it. Buds or scions may be safely transported to any reasonable distance by wrapping them in damp moss or paper, having first deprired them of their foliage. 


\section{PROPAGATION BY GRAFTING.}

This mode of propagation is performed by five different methods, which will be found described under their respective heads, viz:

\section{WHIP-GRAFTING.}

This operation is performed in March and April, by first euttinष off the top of the stock at the desired height. Enter the knife at a smooth place, about three inches below the top, and cut upwards at an acute angle, thereby shaping the stock to a wedge-like form. Having the scion prepared, from four to five inches in length, slope the bottom so as to fit the stock as near as possible, that the inner rinds of both may correspond, especially on the outer side and bottom, as shown in fig. 7. Hold the graft carefully in its position,

Fig. 7 .

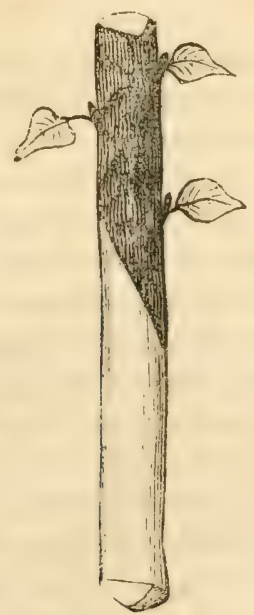

and secure it with matting, twist, or cotton thread, covering the bandage with tempered clay or grafting-wax. The union is formed by the rind or sap, which is directly between the bark and wood, 
and if not placed directly in contact, failure is certain. The stock and scion should be as near in size (diameter) as possible to insure success. The scion should have at least two buds. This is a very strong and handsome mode for standard roses when grafted at the standard height. It makes a handsome finish, covering a part of the stock which, by the other methods, if not trimmed carefully, long remains a sear, and sometimes never become covered with bark. The stocks should never be over an inch in diameter, and nearer the size of the scion the better. If the graft should be successful, it will grow freely. The bandages should then be slightly loosened, but not removed, to allow for the swelling of the wood. Give support by ticing securely, and carefully remove all suckers. In the fall, cut the shoots down to within three or four eyes of the present year's growth.

\section{INN-ARCIING.}

A sort of layering, by the common or slit process, in which the talus or heel intended to throw out fibres, instead of being inserted in the soil, is inserted in the wood, or between the wood and bark of another plant, so as to incorporate with it. It is the most certain mode of propagation with plants difficult to excite to a disposition for rooting; and, when all other modes fail, this, when a proper description of stock is to be found, is sure to succeed. The stock designed to be imn-arched, and the plant from which the layer or shoot is to be selected, should be near together. If the branches of the plant from which the shoots are to be taken are too high for the stocks, the stocks should be planted in pots and elevated on posts or stands. To perform the operation, having first made one of the most convenient branches or shoots approach the stock, mark on the body of the same the part where it will most easily join the stock, and in that part of the shont pare away the bark and part of the wood two or three inches in length, and in the same manner pare the stock in the proper place for the juncture of the shoot. Make a slit uprards in that part 


\section{AND FLOWER-GARDEN DIRECTORY.}

of the branch or shoot, as shown in fig. 8, and make a slit downward in the stock to admit it, as shown in fig. 9. Let the parts then be joined together, slipping the tongue of the shoot into the slit of the stock, making both join in an exact manner, as shown in fig. 10. Tie them elosely together with matting or cotton twist, and cover the whole with tempered clay or graftingwax. In from three to six weeks, the graft will be matured. The shoot should then be sovered from the parent plant, about one inch below the juncture, $(a$,$) and the top of the stock re-$ moved, $(b$,$) thereby transferring the shoot to the stock, and form-$

Fig. 10.

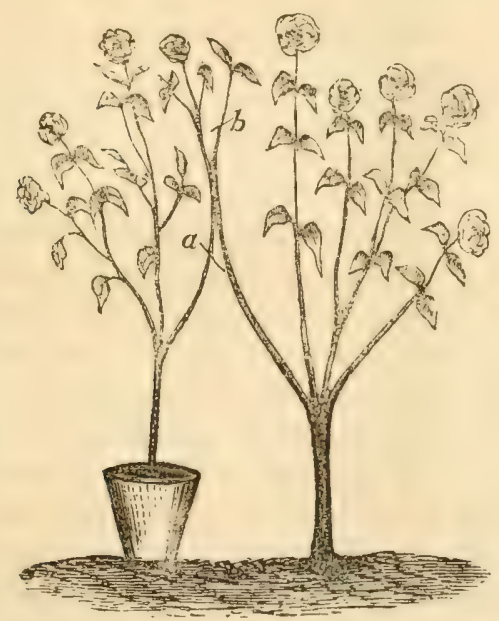

Fig. 9. Fig. 8.
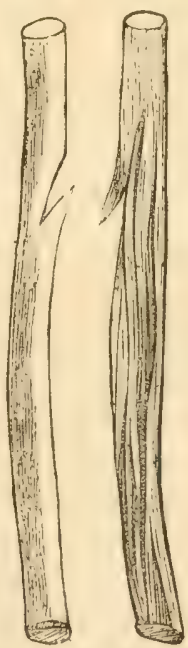

ing a handsome and rigurous plint. The bandages should then be removed, and the ends of both shoot and stock, where severed, neatly trimed, or they will destroy the beauty of the plant. This operation may be performed at any time when the sap is in full motion. 


\section{ROOT-GRAFTING.}

This modo of propagation is performed on detached parts of the roots of removed plants. In general, a piece of the root of the plant of the same genus is selected, in March or April, well furnished with fibres, and a scion placed on it in any of the ordinary methods used for small stocks. Thus united, as shown in fig. 11, bandage with matting or twist, and cover with tempered clay or

Fig. 11.

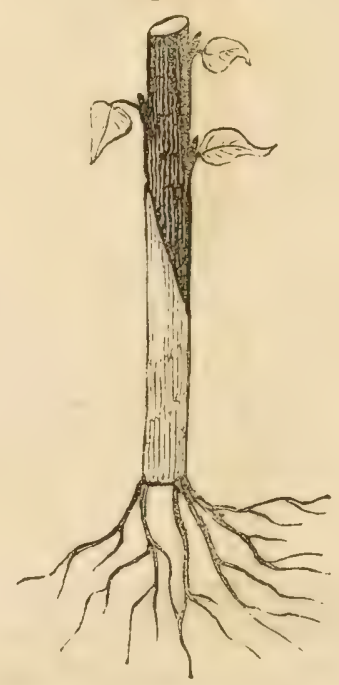

grafting-wax, and plant them deep enough to cover the ball, leaving one eye of the scion at least above ground. In a month after grafting, it may be ascertained whether the scion has united with the stock by observing the progress of its buds. It is not safe to remove the clay or wax under three months, till the graft be completely citratized. When it is taken off, the bandages should be loosened where the scion appears to require more room to expand. 


\section{AND FLOWER-GARDEN DIRECTORY.}

A few weeks after, when the parts have been thus partially inured to the air, and when there is no danger of the scion being blown off by the wind, the whole of the bandages should be removed.

\section{* WEDGE, OR SADDLE-GRAFTING.}

This operation consists in cutting off the top of the stock at any desired height and slitting the same in the centre to the depth of three inches, as shown in fig. 12. The graft should be from

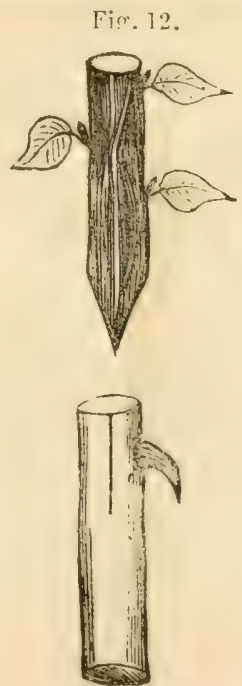

three to four inches in length, and have at least two eyes. This mode of propagation was once in high repute, but, at present, is seldom resorted to. It does not make as fine a finish as either of the other methods, and is very likely to break off from high winds. Having thinned off the wood from each side of the same, so as to enter the slit in the stock readily, fiting the outer rind or bark of the scion in close contact with that of the stock, bandage with matting or twist, and cover the whole with tempered clay or grafting-wax, and treat as described for whip-grafting. 


\section{CLEFT-GRAFTING.}

This method is frequently resorted to for standard roses. The stock used for this purpose should be larger than the graft. The graft should be selected from well-ripened wood, and cut into lengths of three or four inches, having at least two or three eyes or buds. In performing the operation, the stock having been cut down to the desired height, insert the point of the knife at $a$ in fig. 13, nearly to the centre or pith of the stock, and draw it downward, in an oblique direction, one and a half inches below the top of the stock. Again insert the knife at $b$, making a correspoding cut, so that it terminates at a point, $(c$,$) cutting out a$ piece of the stock, and forming an opening in shape like the letter $T$. The graft ( $d$, in fig. 14,) should then be cut to fit the opening

Figr. 14.

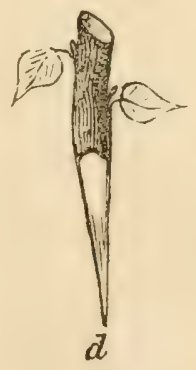

Fig. 15.

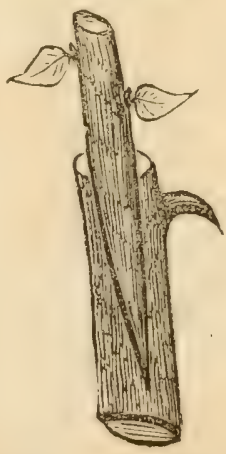

Fig. 13.

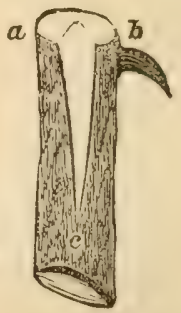

in the stock as near as possible, and the inner rind or bark of both stock and graft should be brought into exact contact, as shown in fig. 15, to insure success. Secure with matting or cotton twist, and cover the juncture with tempered clay or grafting-wax. As soon as the graft begins to make new wood, the bandages should be loosened; and, if the wound is healed they may be removed. 


\section{AND FLOWER-GARDEN DTRECTORY.}

If, however, the union is not perfected, the handares slonuld be replaced, leaving room for the expansion of the wood. Give support by tieing securely, and carefully remove all suckers. Cut the plant down in the fall to within three or four eyes of the present year's growth.

\section{PROPAGATION BY LAYERING.}

The operation of layering is generally commeneed before the ascent of the sap, or delayed until it is fully up. Any young shoot of eighteen inches or two fect in length will serve for this purpose. The shoot intended to becone a new plant, first being gently bent to the ground, and an eye selected at a convenient distance from the mother plant, is half separated, about half an inch below the eye, as shown at $a$ in fig. 15. While this permits

Fig. 15.

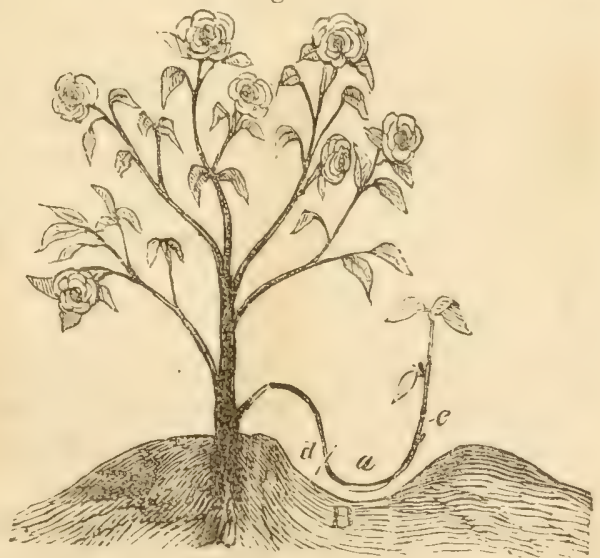

the ascent of the sap at the season of its rising, the remaining half, heing cut through and separated, forms a dam or sluice to the descending sap, which, thus interrupted in its progress, exudes at the wound, in the form of a granulous protruberance, which 
throws out roots. If the cut or noteh in the shoot does not penetrate at least half way through, some plants will not form a nucleus the first season. On the other hand, if the notch be cut nearly through the shoot, a sufficiency of alburnum, or soft wood, is not left for the ascent of the sap, and the shoot dies. A hole, about five inches deep and of the same width, should be made, (it $b$,) and the shoot placed therein, having first removed the leaves from the portion to be covered by the soil. Secure the shoot in its position, and cover with soil about a third of its length. The bottom eye of the upright shoot $(c)$ should be solected for this purpose. Stake securely, and protect against high winds. When the layers are rooted, which will generally be the case by the fall after the operation is performed, they should be severed (at $d$ ) from the parent plant, and, at the option of the operator, may be removed or permitted to remain until the ensuing spring.

In some plants it is not sufficient to cut a notch merely, because, in that case, the descending sap, instead of throwing out granulated matter in the upper side of the wound, would descend by the entire side of the shoot. Besides a notch formed by cutting out a portion of the bark and wood, the notched side should be slit up at least one inch, separating it by a suall chip placed in the same to keep it open.

\section{PLANTING.}

Both spring and fall are selected for this purpose, many persons giving the latter the preference. We advocate the former, deeming it preferable for several reasons, among which are the following:

1. Plants set out in the fall, (remaining dormant through the winter,) do not become set or established in the ground by the making of new roots before the following summer, and, consequently, are less cnabled to withstand the high winds.

2. If the soil be of a wet or retentive nature in winter, the plints placed therein are sure to be injured to more or less extent, if not killed. 
3. When pianted in the fall, the soil does not settle around the roots of plants as in the spring, the same being exposed to the alternating freezing and thawing of the soil, which, to say the least, is very injurious.

4. When planted out in the spring, before the luds begin to swell, they soon commence throwing out new roots, become early established, and will, in a few weeks at most, amply repay for the protection afforded them during the winter.

Crowding plants should be avoided, and frequently prove injurious. Where the grounds are limited, the best varieties only should be planted. Distribute the plants to suit the taste, carefully avoiding formality or studied effect. In setting out plants, particularly roses, excarate a hole about eighteen inches or two feet deep, and place a few pieces of soft brick, broken flower-pots, \&e., in the bottom, and cover with soil three inches deep, and so on in alternate layers of fragments and soil, till you have the same filled up just sufficient to admit the plant to its original depth. If the plants are in pots, turn them bottom-upward, holding your hands on either side, and gently tap the edge of the pot against a post, or other solid object, which will displace the ball of earth unbroken. Moderately loosen the outer edges of the earth surrounding the roots, and straighten such as are matted which may present themselves. Hold the plant in an upright position and insert the same in the hole prepared to receive it, filling in the soil between the roots, draw the same up around it, and press with the foot about the sides to keep it in its position. Prune moderately, water, and secure to a stake by tieing.

\section{PRUNING.}

In order to become proficient in this all-important operation, it is essentially requisite to understand the nature and habit of the plant to be operated upon. This can only be done by practice. The chief difficulty in pruning which the Amateur experiences 
arises from the extensiveness of the genus, differing so much in habit and character. The mode of pruning should be determined by the object of the operator, keeping in view the health and habit of the plant. The beauty of the plant, as well as the quality and disposition to flower, depend on judicious pruning. This operation is performed in spring and autumn. We prefer the former, for, when done in March, the shoots are not likely to be injured by frost, as is freruently the case when the operation is performed in autumn; for should we have a few days of nild weather, the buds become excited and push forth shoots, when, if severe weather follow, they become frosted, and the bloom perishes. The essential directions for pruning roses, will be found under the head of each class, viz:

Multiflora roses should have the old mood only thinned out, unless locality demand it, when the young shoots may be imoderately headed in, early in the spring, before the buds begin to swell.

Moss roses require to have the wood of the preceding year's growth thinned out. The young wood should only be thinned out where they cross each other, and this very moderately. The plants should never be cut down lower than four feet.

Norsette roses may be pruned from November to March. Thin out the old wood of two or three year's growth, and shorten all the shoots in proportion to their growth. Those which have made a 'growth of one or two feet, should be eut to within four or six eyes of the preeeding year's wood; and shoots which have made a srowth of four to ten feet, should be shortened in to three to eight fect; and so in proportion. If pruned in this manner, several varicties will bloom the whole season. The flowering stems shoul? be cut off as soon as they begin to decay, unless the seed be rerpuired, as the ripening of the seed impoverishes the plant and retards the succession of bloom.

Tex-scexted hoses should be pruned only of all decayed or surplus wood, merely sufficient to keep the branches from becoming too crowded. 


\section{AND FLOWER-GARDEN DIRECTORY.}

Bengal roses should have all the dead wood cut out, and the shoots of the preceding year, where irregular and ill shapened, shortened in.

LaWrexcia roses should bave the old and superfluous wood thinned out, only sufficient to keep the branches from becoming two crowded.

Bodrion roses will bear closer pruning than any other variety, but care should be taken not to spoil the appearance of the plant.

Hyrrid Perpetoda roses, being of a very robust growth, should be pruned of all surplus wood. Heading-in of the plant will be found advantageous for this family of the rose.

Perpetual Damasik ruses require the same treatment as recommended for the Hybrid Perpetuals.

Micropirzlia noses should have only the old shoots thinned out. The young shoots should not be pruned unless locality demand it.

Musk-scented roses require the same mode of treatment as recommended for the Noisettes. 


\section{CLASSIFICATION.}

The classification of Roses is somethat arbitrary, and far from being elear and distinct. We have selected such only as have proved to be worthy of cultivation, and shall endeavor to give an accurate description of their habit, growth, color, \&c. In some instances, howerer, we may be mistaken, for it is rather a difficult task to describe accurately the peculiar tints of some roses; beside which, many varieties of the Rose, owing to soil and cultivation, occasionally "sport," presenting, at the same time, different tints and colors. It has been our aim to give the correct name of each, and its synonymes, in order to protect the Amateur against imposition and assist him in his selection.

The cultivation of the Rose is very simple, the main secret consisting in having the soil well drained, palverized, depth, and richness. By keeping the ground free from weeds, and enriching the soil when requisite, with a judicious selection of plants, all can readily secure their successful cultivation.

The Amateur generally finds himself confused when making his selection of plants from the extensive catalogues of nurseymen; for, between the name and color described as appertaining to some particular plant, (named after some celebrated beauty,) his imagination become centered on the charms and loveliness of the original, and he, in all probability, selects those which are comparatively worthless. In order to assist him in making a judicious selection, we have enumerated the best varieties now in cultivation. The synonymes are in italic. 


\section{AND FLOWER-GARDEN DIRECTORY.}

\section{ROSA MUltiflorA.-The Multiflora Rose.}

This family of the rose blooms but once during the season, (in June,) but for which, many of its varieties would have no competitors, either in the beanty or the profusion of their flowers, which are perfectly formed, blooming in clusters, of various colors, varying from a pure white to a deep pink. For covering trelleses, fences, or other objects, but, for this one defect, this class would have no superior. They are perfectly hardy, and, being very strong and rapid growers, any ordinary garden soil will suit them. The pruning of this class should be done very early in the spring, before the buds swell. The plants should be secured to their support by strips of leather, which are preferable to twine, as the latter, on becoming wet, shrink and generally injure the plant. These may be propagated by either of the methods described.

\begin{tabular}{|c|c|c|}
\hline Name. & Color. & Description. \\
\hline Alba, .... & Blush white, & $\begin{array}{l}\text { Cupped and double; about an inch } \\
\text { in diameter, and blooming in } \\
\text { clusters. }\end{array}$ \\
\hline $\begin{array}{l}\text { Grevillia, ...................... } \\
\text { Seven Sisters. }\end{array}$ & Every shade, & $\begin{array}{l}\text { Flowers single, semi-double, and } \\
\text { double. A fine grower, and } \\
\text { blooms in large clusters. }\end{array}$ \\
\hline Laura Davoust, .............. & $\begin{array}{l}\text { Various, ...... } \\
\mid\end{array}$ & $\begin{array}{l}\text { Very strong grower, perfect form, } \\
\text { blooming in very large clusters, } \\
\text { from pure white to a deep pink. } \\
\text { Her beauty must be seen to be } \\
\text { appreciated. When well estab- } \\
\text { lished, will make shoots of } 15 \\
\text { to } 25 \text { feet in one season. }\end{array}$ \\
\hline Nultiflora, ............... & Pink, ... & $\begin{array}{l}\text { Perfectly double and cupped; an } \\
\text { inch in diameter, and blooming } \\
\text { in clusters. }\end{array}$ \\
\hline Multifiora Graulhié, . & Pure white, .. & $\begin{array}{l}\text { Double, strong grower, and free } \\
\text { bloomer; somewhat larger than } \\
\text { the generality of this class. }\end{array}$ \\
\hline $\begin{array}{l}\text { Russelliana, ................. } \\
\text { Scarlet Grevillia. } \\
\text { Russells? Cottage Rose. }\end{array}$ & Crimson,... & $\begin{array}{l}\text { Profuse bloomer, and very attrac- } \\
\text { tive. Many of the flowers often } \\
\text { striped with white.. }\end{array}$ \\
\hline
\end{tabular}




\section{ROSA CENTIFOLIA MUSCOSA.-The Moss Rose.}

Of all the rose family there is no other which will bear a comparison with this much-admired variety while in bud, for herein consists its beauty. When expanded, it looses this peculiar attraction. Its origin remains in obscurity, yet all are sufficiently acquainted with its merits to appreciate the exquisite beauty of its mossy coat. They delight in a deep, rich, sandy loam, and, when well established, will make shoots of two to six feet long in one season. Well-rotted manure should be dug in about their roots every fall. The pruning should be performed with eaution, for when overdone, they do not bloom in perfection, and frequently die after flowering. The Moss rose may be propagated by either of the methods designated, but will be found rather difficult to raise from cuttings, unless bottom heat be given to the soil in which they are placed. Layering and root-budding are the best and most successful methods. The following embrace only the best varieties. Many catalogues are more full than the supply.

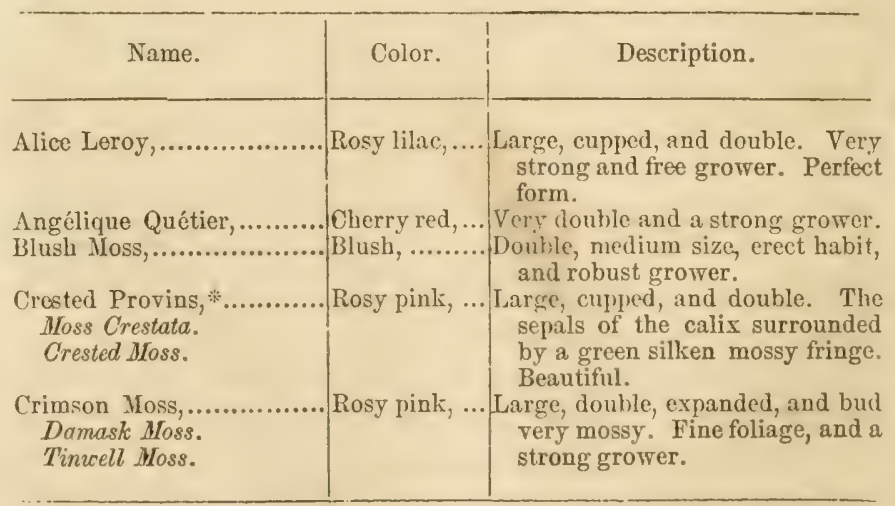

* This curious and beantiful rose is said to he a sport from the Provins Cabbage. The foliage is stronger and of a hetter color than the original. Frequently, but erroneously, classed as a Moss. 


\section{AND FLOWER-GARDEN DIRECTORY.}

ROSA CENTIFOLIA MUSCOSA-Continued.

\begin{tabular}{|c|c|c|}
\hline Name. & Color. & Description. \\
\hline $\begin{array}{l}\text { Crimson Pompon, ,...... } \\
\text { Oscar Foulard. }\end{array}$ & Rosy violet, .. & $\begin{array}{l}\text { Small, full, and compact form. } \\
\text { Branching habit and moderate } \\
\text { grower. Plant very mossy. }\end{array}$ \\
\hline Cointesse de Noé,... & Crimson, $\ldots \ldots$ & $\begin{array}{l}\text { Perfect form, medium size, flower- } \\
\text { ing in large clusters, and a vig- } \\
\text { orous grower. Changeable. }\end{array}$ \\
\hline De Ja Flèche,... & Purplish red, & $\begin{array}{l}\text { Double, cupped, medium size, and } \\
\text { quite mossy. }\end{array}$ \\
\hline Eclatante, . & Pink, . & $\begin{array}{l}\text { Large, double, expunded, strong } \\
\text { grower, and very showy. }\end{array}$ \\
\hline Etna, . & Bril. crimson, & $\begin{array}{l}\text { Large and very double. Beau- } \\
\text { tiful. }\end{array}$ \\
\hline $\begin{array}{l}\text { Gracilis, .... } \\
\text { Minor. } \\
\text { Prolific. }\end{array}$ & Deep pink, & $\begin{array}{l}\text { Large and full, globular, strong } \\
\text { grower, and a free bloomer. }\end{array}$ \\
\hline Héloise, ..... & Rosy crimson & $\begin{array}{l}\text { Medium size, full, compact form, } \\
\text { and strong grower. Desirable. }\end{array}$ \\
\hline $\begin{array}{l}\text { Laffity's Perpetual White } \\
\text { Moss. } \\
\text { Quatre Saisons Mousseux. } \\
\text { New White Cluster Moss. }\end{array}$ & Pure white,.. & $\begin{array}{l}\text { A profuse bloomer, very pretty in } \\
\text { bud, flowering in clusters, and } \\
\text { blooming the whole season. }\end{array}$ \\
\hline ILouise Colet, .................... & Delicate'blush & $\begin{array}{l}\text { Large, double, and cupped. Mod- } \\
\text { erate grower, and shaded with } \\
\text { rosy lilac. }\end{array}$ \\
\hline Malvina, . & Rosy pink, .. & $\begin{array}{l}\text { Large, full, and cupped. Flower- } \\
\text { ing in clusters, and a vigorous } \\
\text { grower. }\end{array}$ \\
\hline $\begin{array}{l}\text { Mauget, ................... } \\
\text { Perpetual Red MIoss. }\end{array}$ & Rosy pink, . & $\begin{array}{l}\text { Growth delicate. Mledium size, } \\
\text { semi-double, and cupped. Will } \\
\text { flower two or three times during } \\
\text { the season. }\end{array}$ \\
\hline $\begin{array}{l}\text { Panachée Pleine, ............ } \\
\text { Double White Striped Moss. }\end{array}$ & White or flesh & $\begin{array}{l}\text { Vigorous grower. Medium size, } \\
\text { very double, and cupped. Oc- } \\
\text { casionally streaked with rose. }\end{array}$ \\
\hline 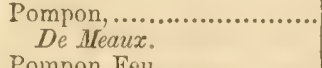 & Delicatepink, & Dwarf habit, small and cupped, \\
\hline Pompon Feu,.. & Bright red,. & $\begin{array}{l}\text { Medium size, full, and expanded. } \\
\text { A free bloomer. Dwarfish babit. }\end{array}$ \\
\hline $\begin{array}{l}\text { Princesse Adelaide, .. } \\
\text { Bourbon Moss. }\end{array}$ & Rosy blush, & $\begin{array}{l}\text { Large, full, and compact form. } \\
\text { Profuse bloomer, flowering in } \\
\text { clusters, and a strong grower. }\end{array}$ \\
\hline Princesse Royale,. & Pur. \& crim., & $\begin{array}{l}\text { Large, double, and cupped. A } \\
\text { strong grower, and beautifully } \\
\text { mottled. }\end{array}$ \\
\hline $\begin{array}{l}\text { Provins Moss, ............ } \\
\text { Onique de Provins. }\end{array}$ & White, . & $\begin{array}{l}\text { Large, full, and cupped. Moder- } \\
\text { ate grower, and blooming in } \\
\text { clusters. }\end{array}$ \\
\hline
\end{tabular}


ROSA CENTIFOLIA MUSCOSA-Continned.

\begin{tabular}{|c|c|c|}
\hline Name. & Color. & Description. \\
\hline $\begin{array}{l}\text { Rouge, ...................... } \\
\text { Ferrugineuse. } \\
\text { Rouge de Luxembourg. } \\
\text { Luxembourg Moss. } \\
\text { Veilland. }\end{array}$ & Crimson,... & $\begin{array}{l}\text { Medium size, expanded, and per- } \\
\text { fectly double. A free bloomer. } \\
\text { Whole plant mossy. }\end{array}$ \\
\hline Sablee, ,....................... & Bright rose, . & $\begin{array}{l}\text { Semi-double. Frequently spotted } \\
\text { with red. }\end{array}$ \\
\hline Sage-Leared Moss,... & Bright rose,.. & $\begin{array}{l}\text { Large, full, and cupped. Moder- } \\
\text { ate grower. Changing to lilac. }\end{array}$ \\
\hline Splendens, ...... & Pale peach, ... & $\begin{array}{l}\text { A vigorous grower, of branching } \\
\text { habit. Large, expanded, and } \\
\text { double. }\end{array}$ \\
\hline $\begin{array}{l}\text { White Batb,.................... } \\
\text { Clifton Moss. }\end{array}$ & Pure white,... & $\begin{array}{l}\text { Large, full, and globular. Beau- } \\
\text { tiful in bud, but rather delicate } \\
\text { growth. Somewhat deficient in } \\
\text { the mossy coat. }\end{array}$ \\
\hline
\end{tabular}

ROSA MOSCHATA.-The NoIsLTte Rose.

This family of the rose is quite hardy in this latitude when planted in proper positions. If the most tender varieties be planted on the nort $\bar{h}$ side of a fence or building, so as to protect them from the sun in winter, they will need little, or no other protection A soil of deep, rich, sandy loam, with a dry or gravelly bottom, suit them best. When planted in a position where they receive the full glare of the sun in winter, most of this class will need more or less protection. The ground should be enriched every fall by the addition of well-rotted manure. Sevcral varieties of this class are of dwarfish habit, which will be found designated by an asterisk, (*.)

To the accidental fertilization of the Chinese with the Mask rose, it is said, is due the origin of this beautiful family of the rose. They are admirably adapted for covering verandahs, buildings, \&c. When not wanted for this purpose, they should be cut 


\section{AND FLOTVER-GARDEN DIRECTORY.}

down to within three or four feet of the ground every season. When desired for the former, they should be well secured to whatever they are trained, by leather straps, tacked to the wood-work, as strings are always injurious to the plant, being liable to shrink from dampness. The varieties which most need protection will be found designated by the single dagger, (†.) The profusion and beauty of their flowers, produeed in immense clusters, render this class of the rose well worthy a place in every garden. Both the beauty of the flowers and the profusion of bloom will be greatly promoted by the removal of the decayed flower-stems.

\begin{tabular}{|c|c|c|}
\hline Name. & Color. & Description. \\
\hline lba,,. & Purewhite, & $\begin{array}{l}\text { Small, profuse bloomer, and makes } \\
\text { a beautiful dwarf bush. }\end{array}$ \\
\hline Abbe Meillon, *... & Rosy red, & Perfect form and profuse bloomer \\
\hline $\begin{array}{l}\text { Aimée Vibert, *............ } \\
\text { Nevia. }\end{array}$ & Pure white,... & $\begin{array}{l}\text { Mledium size, com } \\
\text { flowering in lar }\end{array}$ \\
\hline Aimée Vibert Scandens,. & Pure white, ... & $\begin{array}{l}\text { A climber; similar to the above in } \\
\text { size and form, but producing } \\
\text { bloom in less abundance. }\end{array}$ \\
\hline lzande, ..... & Pale pink,... & $\begin{array}{l}\text { Very double, fragrant, and of me- } \\
\text { dium growth. }\end{array}$ \\
\hline urora, ... & Straw,.. & $\begin{array}{l}\text { Very double, petals fringed, fra- } \\
\text { grant, and a strong grower. }\end{array}$ \\
\hline $\begin{array}{l}\text { Belle D'Esquermes, .. } \\
\text { Camellia Rouge. }\end{array}$ & Bright red, . & $\begin{array}{l}\text { Semi-double, medium size, a fin } \\
\text { bloomer, and an excellent pil- } \\
\text { lar rose. }\end{array}$ \\
\hline Belle Marseillai, & Crimson, & $\begin{array}{l}\text { Double, a moderate grower, and } \\
\text { very distinct. }\end{array}$ \\
\hline Boulogne, .... & Violet,.. & $\begin{array}{l}\text { Small, but perfect, and a profuse } \\
\text { bloomer. }\end{array}$ \\
\hline $\begin{array}{l}\text { Chimpneyana, ............... } \\
\text { Champney's Pink Cluster }\end{array}$ & Light pink, ... & $\begin{array}{l}\text { Profuso bloomer, quite hardy, and } \\
\text { a strong grower. }\end{array}$ \\
\hline Charles the Tenth, & Rosy purple,. & $\begin{array}{l}\text { Larce, semi-double, and a profuse } \\
\text { bloomer. }\end{array}$ \\
\hline hloris, & & Double and of medium \\
\hline & Light yellow, & $\begin{array}{l}\text { Large and double, changing to } \\
\text { white. }\end{array}$ \\
\hline $\begin{array}{l}\text { Cloth of Gold, }+\ldots . . . \\
\text { Chromatelle. }\end{array}$ & Light ycllow, & $\begin{array}{l}\text { Large, double, and fragrant. Re- } \\
\text { quires to be well estahlished to } \\
\text { bloom freely. Decidedly the best } \\
\text { yellow ever-blooming rose. }\end{array}$ \\
\hline Comtesse de Grillon, & Pale pink, . & $\begin{array}{l}\text { Very double, fragrant, and strong } \\
\text { grower. Blooming in clusters. }\end{array}$ \\
\hline
\end{tabular}


ROSA MOSCHATA-Continued.

\begin{tabular}{|c|c|c|}
\hline Name. & Color. & Description. \\
\hline Comtesse d'Orloff,............ I & Rosy yink,... S & Simall, rapid grower, and a free \\
\hline Comtesse de Tolosan, ........ & White, & $\begin{array}{l}\text { Very double, large, and cupped. } \\
\text { A moderate grower, and very } \\
\text { pretty. }\end{array}$ \\
\hline Comtesse Odoisse, ... & Pink, .......... D & $\begin{array}{l}\text { Double, cupped, and of medium } \\
\text { size. A vigorous grower. }\end{array}$ \\
\hline Conque de Venus,.... & Creamy white $\mathrm{P}$ & $\begin{array}{l}\text { Perfectly double, fragrant, and a } \\
\text { profuse bloomer. Centre bright } \\
\text { pink, and flowering in clusters. }\end{array}$ \\
\hline Cora L. Barton, .............. & Rosy pink,... V & $\begin{array}{l}\text { Very large, double, cupped, and } \\
\text { fragrant. A profuse bloomer, } \\
\text { of strong habit. }\end{array}$ \\
\hline Donna Maria, & Rose, & $\begin{array}{l}\text { Nedium size, cupped, full, and a } \\
\text { moderate grower. Changing to } \\
\text { white. Very pretty. } \\
\text { Small, full, and cupped. Very } \\
\text { pretty. }\end{array}$ \\
\hline Du Luxembourg, $† \ldots . . . . . .$. & Rosy purple, I & $\begin{array}{l}\text { Large, rery double, fragrant, and } \\
\text { free bloomer. Strong grower. }\end{array}$ \\
\hline Eugenia Dubourg,.. & Pale pink,,$\ldots$. & Mellium size, full, and cupped. \\
\hline $\begin{array}{l}\text { Eugene Pirolle, }{ }^{*} . . . . . . . . . . . \\
\text { Admiral de Rigny. }\end{array}$ & Bright rose, & $\begin{array}{l}\text { A modect form, blooming in large } \\
\text { clusters. }\end{array}$ \\
\hline Euphrosine, $† \ldots . . \cdots \cdots \cdots \cdots \cdot \ldots$ & Rosy Luff,. & $\begin{array}{l}\text { Very double, large, and cupped. } \\
\text { Very fragrant and a moderate } \\
\text { grower. }\end{array}$ \\
\hline Fellenburg, ......... & Pale red,..... & $\begin{array}{l}\text { Medium size, double, and cupped. } \\
\text { An abundant bloomer and a } \\
\text { fine grower. }\end{array}$ \\
\hline $\begin{array}{l}\text { Fleur de Jeune Age } † \ldots . . . . \\
\text { Lamarque à car rose. }\end{array}$ & Yell'sh white, & $\begin{array}{l}\text { A profise bloomer, fragrant, and } \\
\text { a rapid grower. Blooming in } \\
\text { clusters. }\end{array}$ \\
\hline $\begin{array}{l}\text { Jaune Desprez,............... } \\
\text { Desprez D'Arcole. } \\
\text { French Yellow Noisette. }\end{array}$ & Rosy buff, ... & $\begin{array}{l}\text { Perfectly ilouble, profuse bloomer, } \\
\text { fragrant, and blooming in clus- } \\
\text { ters. }\end{array}$ \\
\hline Jeannie d'Arc, .............. & Pure white, ... & $\begin{array}{l}\text { Cupped and very double. Flowers } \\
\text { rather small. A strong grower. }\end{array}$ \\
\hline $\begin{array}{l}\text { Julia, ......................... } \\
\quad \text { Julia Dante. }\end{array}$ & Creamy blush & $\begin{array}{l}\text { Double, fragrant, and a profuse } \\
\text { bloomer. }\end{array}$ \\
\hline Julienne Le Sourde, *.... & . Bright pink, . & $\begin{array}{l}\text { Cupped. A very profuse bloomer } \\
\text { if planted in rich soil. }\end{array}$ \\
\hline La Biche,,................ & - Pale blush,... & $\begin{array}{l}\text { Very large, double, and cupped. } \\
\text { A free grower, changing to pure } \\
\text { white. }\end{array}$ \\
\hline Lactans, *..... & Milky white, & $\begin{array}{l}\text { Very larece, double, and a free } \\
\text { bloomer. }\end{array}$ \\
\hline
\end{tabular}




\section{AND FLOWER-GARDEN DIRECTORY.}

ROSA MOSCHATA-Continued.

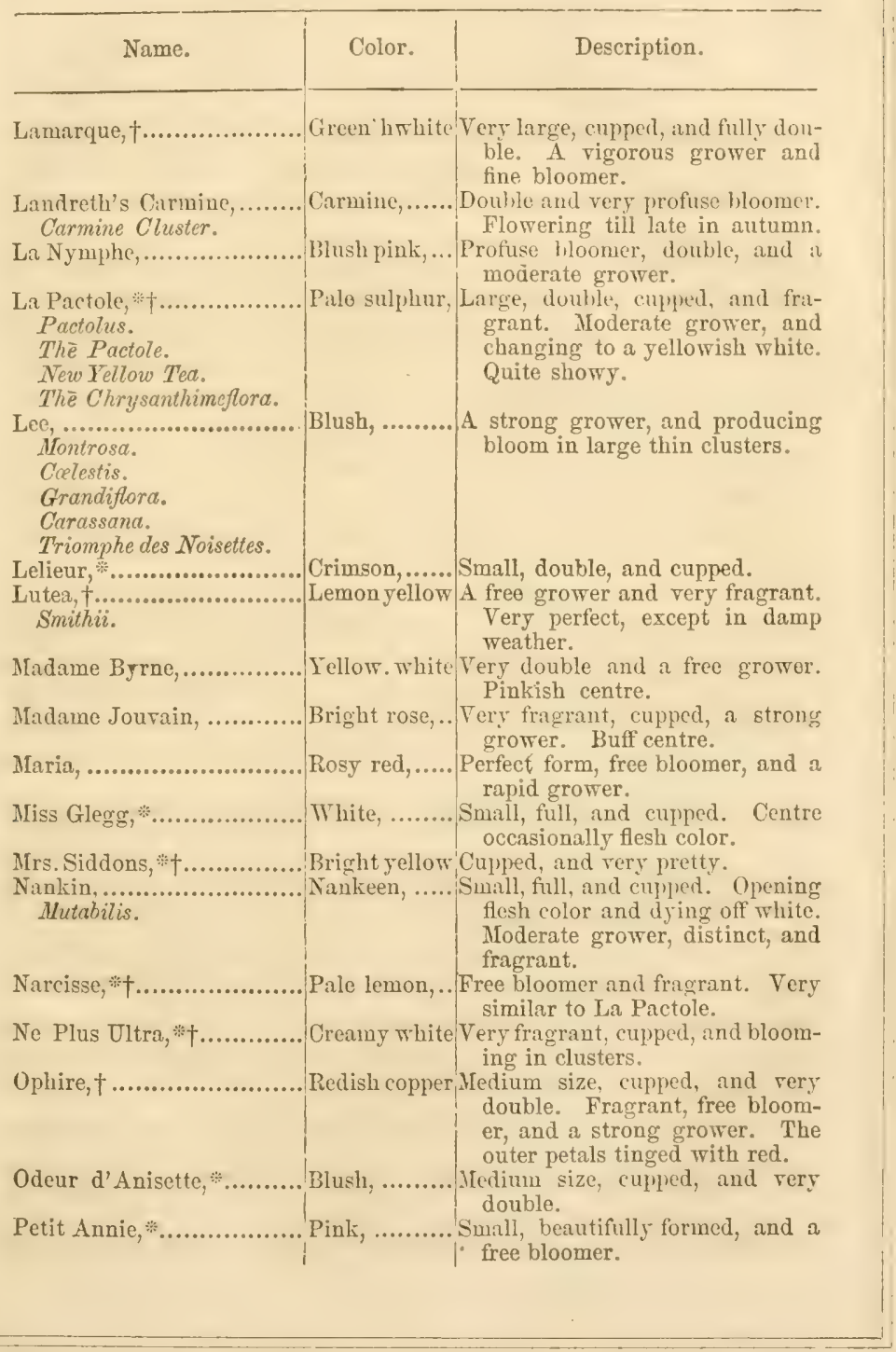




\section{THE AMATEURS' GUDE}

ROSA MOSCHATA-Continued.

\begin{tabular}{|c|c|c|}
\hline Name. & Color. & Description. \\
\hline Prudence Rosser,... & Pink, .. & Medium size, cuppud, and double. \\
\hline $\begin{array}{l}\text { Similor, }{ }^{*}+\ldots . . \\
\text { Le Similor. }\end{array}$ & Creamy buff,. & $\begin{array}{l}\text { Simall, cupped, and very double. } \\
\text { Centre rose and fawn color. } \\
\text { Dying off white. }\end{array}$ \\
\hline Sir Walter Scott,... & Rosy lilac,... & $\begin{array}{l}\text { Large, cupped, and double. A } \\
\text { free grower, and fragrant. }\end{array}$ \\
\hline Solfatare $\nmid \uparrow \ldots \ldots \ldots \ldots \ldots$ & Sulphur yel... & $\begin{array}{l}\text { Very large, cupped, double, and } \\
\text { fragrant. Very strong grower. }\end{array}$ \\
\hline Triomphe de la Duchère,... & Pale rose, .... & $\begin{array}{l}\text { Merlium size, cupped, and doulle. } \\
\text { Fragrant, blooming in large clus- } \\
\text { ters. A very strong grower and } \\
\text { free bloomer. }\end{array}$ \\
\hline $\begin{array}{l}\text { Victorieuse, }{ }^{*} \text {.................. } \\
\text { Pictorium. } \\
\text { La Victorieuse. }\end{array}$ & Pale blush, ... & $\begin{array}{l}\text { Large, fragrant, and blooming in } \\
\text { clusters. }\end{array}$ \\
\hline Vitellina $+\ldots \ldots \ldots \ldots \ldots \ldots \ldots .$. & White, ......... & $\begin{array}{l}\text { Medium size, cupped, and doul,le. } \\
\text { A vigorous grower, with varia- } \\
\text { ble centre. }\end{array}$ \\
\hline Zictrude,.............. & Bril. crimson, & $\begin{array}{l}\text { Medium size, cupped, and very } \\
\text { double. Shaded with blackish } \\
\text { purple. }\end{array}$ \\
\hline
\end{tabular}

ROSA INDICA ODORATA.-The TeA-scented Rose.

This family of the rose is more tender than either of the other classes; some few varieties, however, will stand our winters without protection. Generally, they should be protected by having straw or the branches of evergreens placed around them. They delight in a light, rich soil, with a dry bottom, and in an elerated position. The precautions mentioned under the head of "Planting," in regard to pieces of broken flower-pots, \&c., are particularly applicable to this family of the rose. The Tea-rose embraces nearly every shade of color; all of which may be propagited by either of the methods designated. Every garden should have a collection of this lovely family. Their fragrance are unsur-- 
lats-ed, all of the class emitting a delightful odor. Those designiatcd with an asterisk (*) particularly require protection. 'The ranoval of them from the ground for protection during winter, ancl again planting them out in the spring, should never be resorted to, for it retards their growth and perfect flowering, and is every way injurious.

\begin{tabular}{|c|c|c|}
\hline Name. & Color. & Description. \\
\hline 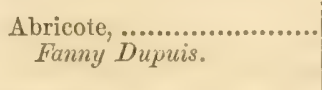 & Apricot, . & $\begin{array}{l}\text { Large, cupped, and double. Vig- } \\
\text { orous grower, and a beautiful } \\
\text { rose. Margin flesh color. }\end{array}$ \\
\hline Adam,,...... & Deep blush,. & $\begin{array}{l}\text { Very large, globular, and per- } \\
\text { fect. I strong grower, and } \\
\text { fragrant. }\end{array}$ \\
\hline $\begin{array}{l}\text { Autherose, .................... } \\
\text { Anteros. }\end{array}$ & Pink'h white, & $\begin{array}{l}\text { Very double, cupped, and a very } \\
\text { strong grower. Blooms well; } \\
\text { centre shading to yellow. }\end{array}$ \\
\hline $\begin{array}{l}\text { Archduchesse Thérèse, ..... } \\
\text { Isabel. }\end{array}$ & P'urew & $\begin{array}{l}\text { Lare, cupped, and double. Re- } \\
\text { quires to be thinned out to make }\end{array}$ \\
\hline $\begin{array}{l}\text { Archinto, } . . . . . . . . . \\
\text { Arkinto. } \\
\text { Belle Archinto. }\end{array}$ & Flesh,.... & $\begin{array}{l}\text { Cupped and very double. Grow- } \\
\text { ing and flowering freely. Bot- } \\
\text { tom of petals yellow. }\end{array}$ \\
\hline Barbot, ............. & Creamy blush & $\begin{array}{l}\text { Large, fragrant, and strong grow- } \\
\text { er. Uccasionally deep pink. }\end{array}$ \\
\hline Belle Allewavde,............ & Delicate pink, & $\begin{array}{l}\text { Tery large, double, and expanded. } \\
\text { A free bloomer and very fra- } \\
\text { grant. Often tinged with fawn } \\
\text { color. Variable. }\end{array}$ \\
\hline Belle Marguerite, ............. & Rosy lilac, .... & $\begin{array}{l}\text { Perfectly double, of strong habit, } \\
\text { and a profuse bloomer. Ex- } \\
\text { panded, robust grower, and fre- } \\
\text { quently of a dark crimson color. }\end{array}$ \\
\hline Bon Silene, $. . . . . . . \ldots \ldots . . . . .$. & & $\begin{array}{l}\text { Double, fragraut, and larce petals. } \\
\text { Changing to cherry red. }\end{array}$ \\
\hline Bougère,,......... & Salmon, .... & $\begin{array}{l}\text { Very large, perfectly double, and } \\
\text { globular. A strong grower, } \\
\text { and fragrant. }\end{array}$ \\
\hline Bride of $A b y d o s, \ldots . . .$. & White,.. & $\begin{array}{l}\text { Very large, expanded, and double. } \\
\text { A free bloomer, delicately tinged } \\
\text { with pink. }\end{array}$ \\
\hline Buret, ................. & Crimson,... & $\begin{array}{l}\text { Medium size, globular, vigorous } \\
\text { grower, and a free bloomer }\end{array}$ \\
\hline Cirroline, ,........ & 'Rusy pink, . & $\begin{array}{l}\text { Large and cupped, Growing and } \\
\text { flowering freely, in clusters. }\end{array}$ \\
\hline Charles Rejbaud, & Pinl & Large and double. Blooms freely, \\
\hline
\end{tabular}


ROSA INDICA ODORATA-Continued.

\begin{tabular}{|c|c|c|}
\hline Name. & Color. & Description. \\
\hline $\begin{array}{l}\text { Clara Sylrain, ......... } \\
\text { Lady Warender. }\end{array}$ & Pure white, .. & $\begin{array}{l}\text { Large, lerfect form, strong grow- } \\
\text { er, and free bloomer. One of the } \\
\text { best of the white Teas. }\end{array}$ \\
\hline Comte de Paris,........ & Creamy blush & $\begin{array}{l}\text { Tery large, full, cupped, and dou- } \\
\text { ble. Strong labit, and large } \\
\text { buds. }\end{array}$ \\
\hline Comte de Osmond,... & Flesh,,$\ldots \ldots \ldots$ & $\begin{array}{l}\text { Very large, full, and cupped. A } \\
\text { fine rose. Shaded. }\end{array}$ \\
\hline Deroniensis, *................. & Creamy white & $\begin{array}{l}\text { Very large, double, and free grow- } \\
\text { er. Decidedly the most fragrant } \\
\text { of the Teas. Very desirable. }\end{array}$ \\
\hline Delphine Gaudôt,... & Pure white, ... & $\begin{array}{l}\text { Double, cupped, and fragrant. A } \\
\text { profuse bloomer, and flowering } \\
\text { in clusters. }\end{array}$ \\
\hline Drémont,... & Pale flesh, ... & $\begin{array}{l}\text { Medium size, cupped, and rery } \\
\text { double. Centro inclining to } \\
\text { fawn color. }\end{array}$ \\
\hline Duchesse de Mecklenburg, . & Creamy yel., & $\begin{array}{l}\text { Large, cupled, double, and perfect } \\
\text { form. }\end{array}$ \\
\hline Eliza Sauvage, *... & Creamy yel., & $\begin{array}{l}\text { Very large, globular, and double. } \\
\text { Beautiful, but rather tender, }\end{array}$ \\
\hline Eugénie Desgaches,. & Rose,$\ldots \ldots \ldots$ & $\begin{array}{l}\text { Large, cupped, and full. A vig- } \\
\text { orous grower. }\end{array}$ \\
\hline $\begin{array}{l}\text { Flavescens, }{ }^{*} . . . . . . . . . . . . . . . . \\
\quad \text { Yellow Tea. }\end{array}$ & Pale straw, ... & $\begin{array}{l}\text { Large and double. Beautiful when } \\
\text { half open, but loose when fully } \\
\text { expanded. }\end{array}$ \\
\hline Floralie,...... & Rosy blush,. & $\begin{array}{l}\text { Perfect form, and blooming pro- } \\
\text { fusely, in clusters. }\end{array}$ \\
\hline $\begin{array}{l}\text { Fragoletta, } . . . . . . \\
\text { Roi des Belges. } \\
\text { Napoleon. }\end{array}$ & Pale rose,... & $\begin{array}{l}\text { Large, cupped, and double. Per- } \\
\text { fect form and fragrant. }\end{array}$ \\
\hline Gigantesque,...... & Pale flesh, .... & $\begin{array}{l}\text { Very large and showy, but defi- } \\
\text { cient in form. }\end{array}$ \\
\hline Gobault, ...... & Rosy blush, .. & $\begin{array}{l}\text { Very large, expanded, and double. } \\
\text { Free grower, fragrant, and cen- } \\
\text { tre inclining to yellow. }\end{array}$ \\
\hline Hamon,, *................... & Blush, ... & $\begin{array}{l}\text { Large, cupped, and very double. } \\
\text { Fragrant, and a profuse bloom- } \\
\text { er. Changing to a deep rose } \\
\text { color. }\end{array}$ \\
\hline $\begin{array}{l}\text { Hardy, ....................... } \\
\quad \text { Glorie de Hardy. }\end{array}$ & Pale pink, $\ldots$ & $\begin{array}{l}\text { Medium size, cupped, and very } \\
\text { double. A free bloomer, and } \\
\text { very fragrant. }\end{array}$ \\
\hline Hỹuénée, .. & Creamy white & $\begin{array}{l}\text { Perfectly double, profuse bloomer, } \\
\text { and free grower. }\end{array}$ \\
\hline IIfppolyte, . & Creamy ycl., & $\begin{array}{l}\text { Large and double. A frec grower } \\
\text { and profuse bloomer. }\end{array}$ \\
\hline
\end{tabular}




\section{AND FLOWER-GARDEN DIRECTORY.}

ROSA INDICA ODORATA-Continued.

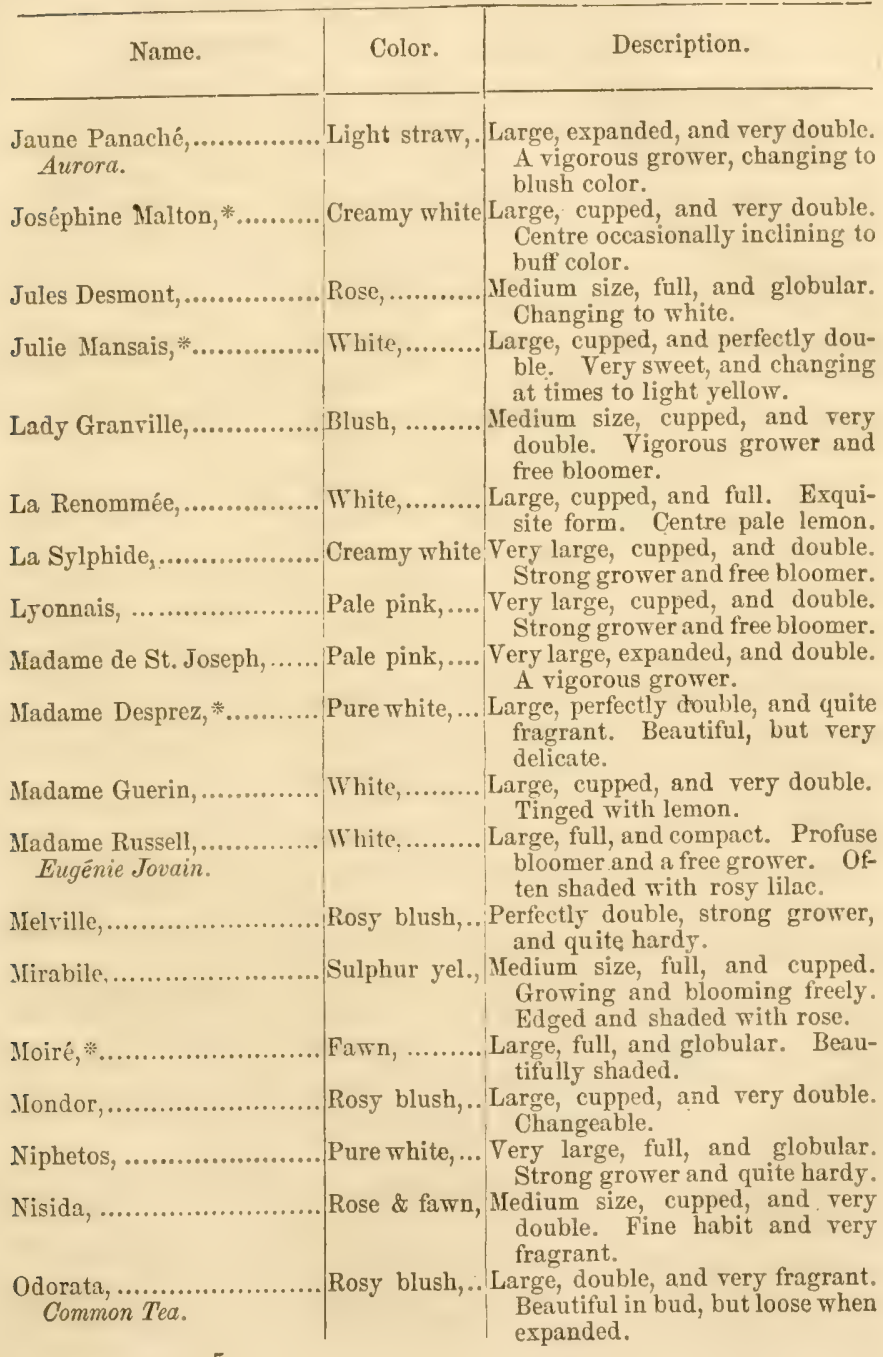




\section{ROSA INDICA ODORATA-Continued.}

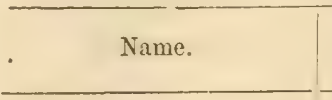

Original,

Color.

Description.

Pauline Plantier,

Creamy white Large and full, with a buff centre. A free grower.

,........... Creamy white Medium size, globular, and full.

Pellonia, ...................... Pale yellow,... Large, globular, and very double.

Perfection, .................. Creamy yel., Medium size, cupped, and double. Quite fragrant, and edged with buff.

Prince d'Esterhazy, ......... Buff, .......... Very large, globular, and very double. Centre rose color, and deliciously fragrant.

Princesse Adelaide,......... Straw, ......... Large, cupped, and full. Very fragrant.

Princesse Hélène Modeste,... White, ......... Very large, cupped, and full. Robust gromer, and yellowish centre.

Princesse Maria, ............ Rosy pink, ... Large, cupped, and full. Strong

Reine de Bassaro,........... Rose, ......... Very large, cupped, and double.

Rêve du Bonheur,........... Creamy blush Medium size, double, and early

Happy Dream. bright red.

Sifrano, *................... Saffron,

Large, cupped, and very double. Desirable.

Siléne,

Rose,

Very large, cupped, and full. Robust grower, and very sweet. Variable, changing to crimson.

Strombio, ................... Creamy white Large, cupped, and very double. Profuse bloomer. Centre changing to yellow.

Taglioni, .................... Creamy white Large, cupped, and full. A fine grower, and quite hardy. Centre tinged with lemon.

Thémistocles,

White, ....

Large, cupped, and full. Centre inclining to blush.

Triomphe du Luxembourg* Rosy buff, .... Very large, globular, and full. A strong grower, free bloomer, and quite fragrant.

Talentine, Pale pink, .... Medium size, cupped, and rery double. Centre deep pink.

Viscomtesse de Cazes, ....... Orange yel., Large, cupped, and very double. Beantiful. Often tinged with copper color.

Victoria Modeste, ............Deep blush,... Very large, cupped, and donble. A strong grower. 
rosa indicA.-Bengat Chinese, or Daily Rose.

The varieties of this class and Rosa Semperflorens we shall include in the same group, for the habits and colors so nearly resemble each other, it is next to impossible to say to which species they belong. They are of a hardy nature, and generally will stand our winters without protection They should have a rich sandy soil, of eighteen inches depth. The Bengals may be propagated by cuttings from June to September, inclusive. If done in June, they will make handsome plints by the fall. For ordinary garden purpuses, layering is preferable, and by far the safest method. This may be done in July or August.-(See Layering.) Well-rotted maune should be dug in about their roots in the fall.

\begin{tabular}{c|c|c}
\hline Name. & Delor. \\
\hline
\end{tabular}

Albé Mioland, Redish purple Large, very double, and globular. Often shaded with white.

Alcine, Br't rosy red, Large, cupped, and double.

Arance de Navaro, Pale rosy p'k, Double and very profuse bloomer.

Archduke Charles, Bright rose,.. Very large, expanded, full, and a

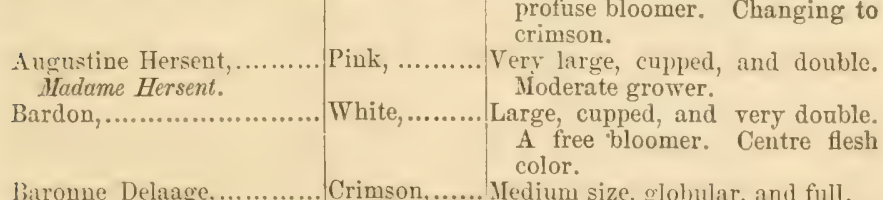

Beau Carmin, Dark crimson Medium size, cupped, and very purple. double. A free grower and profuse bloomer.

Belle de Monza,.............. Light rose,... Perfectly double and a strong grower. Changing to a dark crimson color.

Belle de Florence,

Pale crimson, Medium size, cupped, and semidouble. Profuse bloomer, and flowering in clusters.

Belle Emilie, ................ Blush, ........ Large, explanded, and double, with

Thérèsia Stravius.

Belle Ferrounière, flesh-colored centre.

Blush, ........ Very large, cuppred, and double. Quite showy. Centre flesh color. 
ROSA INDICA-Continued.

\begin{tabular}{|c|c|c|}
\hline Name. & Color. & Description. \\
\hline Belle Isadore,.. & Crim. \& blush & $\begin{array}{l}\text { Large and cupped. A free grower } \\
\text { and profuse bloomer. Various- } \\
\text { ly shaded. }\end{array}$ \\
\hline Boisnard,. & Pale sulphur, & $\begin{array}{l}\text { Large and cupped. Changing to } \\
\text { nearly white. }\end{array}$ \\
\hline Camellia Blanc,.. & White, ....... & $\begin{array}{l}\text { Large, globular, and very double. } \\
\text { A free bloomer. }\end{array}$ \\
\hline Camelliaflora, . & Rosy red,... & $\begin{array}{l}\text { Large and very perfect. Chang- } \\
\text { ing to dark red. }\end{array}$ \\
\hline Caméléon,. & Light pink,... & $\begin{array}{l}\text { Double, strong grower, and grad- } \\
\text { ually changing to crimson. }\end{array}$ \\
\hline $\begin{array}{l}\text { Carmin d'Yebles,.... } \\
\text { Carmin Superbe. }\end{array}$ & Br't carmine, & $\begin{array}{l}\text { Medium size, cupped, and double. } \\
\text { A very pretty and free-blooming } \\
\text { rose. }\end{array}$ \\
\hline Cels Multiflora,.. & Pink blush,. & $\begin{array}{l}\text { Perfectly double, cupped, and a } \\
\text { profuse bloomer. Does not open } \\
\text { well early in the season. }\end{array}$ \\
\hline $\begin{array}{l}\text { Comble de Gloire,........ } \\
\text { Thē Buret. } \\
\text { Gros Charles. }\end{array}$ & Rich crimson, & $\begin{array}{l}\text { Large, expanded, and double. A } \\
\text { free grower, fragrant, and good } \\
\text { bloomer. }\end{array}$ \\
\hline $\begin{array}{l}\text { Cramoisie Supérieur,..... } \\
\text { Aggrippina. }\end{array}$ & Velvety crim. & $\begin{array}{l}\text { Medium size, cupped, and double. } \\
\text { A moderate grower, beautiful, } \\
\text { and should be in every collec- } \\
\text { tion. }\end{array}$ \\
\hline $\begin{array}{l}\text { Don Carlos, .............. } \\
\text { Jeannie Deans. }\end{array}$ & & $\begin{array}{l}\text { Large, cupped, and double. Cen- } \\
\text { tre salmon color. }\end{array}$ \\
\hline Duchess de Kent,.. & Pale & $\begin{array}{l}\text { Small, cupped, and full. Dwarf- } \\
\text { ish habit. }\end{array}$ \\
\hline $\begin{array}{l}\text { Etna, } \ldots . . . . \\
\quad L ' E t n a .\end{array}$ & Rose to crim. & $\begin{array}{l}\text { Large, expanded, and very beau- } \\
\text { tiful. Petals often tinged with } \\
\text { scarlet. }\end{array}$ \\
\hline $\begin{array}{l}\text { Eugène Beauharnais, ..... } \\
\text { Prince Eugēne. }\end{array}$ & Rich crimson, & $\begin{array}{l}\text { Large, cupped, and very double. } \\
\text { Buds beautiful when unfolding. }\end{array}$ \\
\hline Eugène Hardy, . & Whi & $\begin{array}{l}\text { Medium size, cupped, and perfect- } \\
\text { ly double. Centre flesh color. }\end{array}$ \\
\hline Fanny Duval,...... & & $\begin{array}{l}\text { Large and cupped, with flesh-col- } \\
\text { ored centre. }\end{array}$ \\
\hline $\begin{array}{l}\text { Fabvier, ................... } \\
\text { Noisette Aggrippina. }\end{array}$ & & $\begin{array}{l}\text { Medium size, semi-double, and } \\
\text { very showy. }\end{array}$ \\
\hline Général Soyez,... & Cherry crim., & $\begin{array}{l}\text { Large, cupped, and double. Beau- } \\
\text { tiful in autumn. }\end{array}$ \\
\hline Henry the Fifth,. & Crim. scarlet, & $\begin{array}{l}\text { Large, cupped, and very double. } \\
\text { Often striped with white. }\end{array}$ \\
\hline Hortensia,.. & Blush pink, . & $\begin{array}{l}\text { Perfect form, strong grower, and } \\
\text { a profuse bloomer. }\end{array}$ \\
\hline $\begin{array}{l}\text { Indica, ............ } \\
\text { Pink Daily. }\end{array}$ & & $\begin{array}{l}\text { Semi-double, strong grower, and } \\
\text { a profuse bloomer. }\end{array}$ \\
\hline
\end{tabular}




\section{AND FLOWER-GIRDEN DIRECTORY.}

ROSA INDICA-Continued.

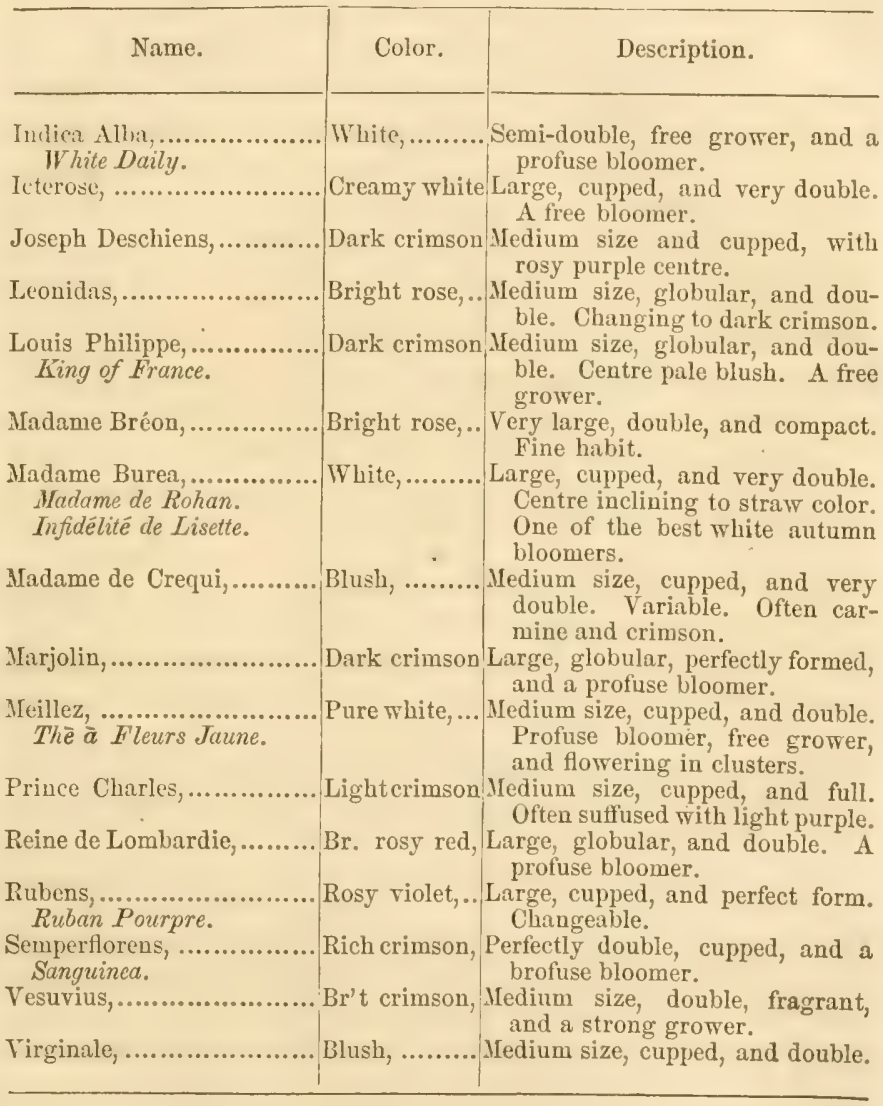




\section{ROSA LAIVRENCIANA.-The Minniature Rost.}

This family, as its name implies, consists of plants of dwarfish Labit. The low growth of these plants and the small size of their flowers present a striking contrast in comparison to the other varieties. 'They should be grown by themselves, for, when planted among the strong and rapid growers, their beauty will be comparatively lost sight of. These beautiful little plants vary in color from white to dark crimson; and, when planted in good rich soil, frequently combine the loveliness and beauty of some of the larger varieties in miniature. These should be propagated from cuttings, their diminitive size rendering them troublesome by the other methods. The treatment recommended for 'Tea roses is applicable to this class.

\begin{tabular}{|c|c|c|}
\hline Name. & Color. & Description. \\
\hline $\begin{array}{l}\text { Alba, ........................ } \\
\text { Caprice des Dames, } \\
\text { Gloire, ............................ } \\
\text { La Miniature, ................ } \\
\text { Pompon, .................... } \\
\text { Indica Minor. } \\
\text { Nemesis, ..................... }\end{array}$ & $\begin{array}{l}\text { Pure white,.. } \\
\text { Pink, .......... } \\
\text { Crimson, ...... } \\
\text { Bright pink,. } \\
\text { Light rose,... } \\
\text { Crimson, ...... }\end{array}$ & $\begin{array}{l}\text { Perfect in form. Beautiful. } \\
\text { Double and quite distinct. } \\
\text { Flowers about the size of a dime. } \\
\text { Plant about ten inches high. } \\
\text { Flowers the size of a balf-dime. } \\
\text { Plant, when full grown, about } \\
\text { six inches high. } \\
\text { Double and perfect. Growth about } \\
\text { one foot high. } \\
\text { The largest and most robust of the } \\
\text { family. }\end{array}$ \\
\hline
\end{tabular}

ROSA BOURBONIANA,-ThE Bourbon Rose.

This class of roses are perfectly hardy in this latitude, and are decidedly the favorite with a large majority of rose fanciers. They are generally of a strong and vigorous growth, producing 
a constint succession of bloom the whole season. They delight in a strong rich soil, and will bear moderately close pruning. The decayed flower-stems should be removed, unless the seed be desired. The Bourbons form handsome standard plants, and may be propagated by either of the methods described.

\begin{tabular}{|c|c|c|}
\hline Name. & Color. & Description. \\
\hline Acidalie,...... & Pale white, ... & $\begin{array}{l}\text { Large, full, and globular. Vig- } \\
\text { orous grower. }\end{array}$ \\
\hline Amarantine, & Rosy pink, .... & Large, cupped, and double. Mod- \\
\hline Amenaide, .. & Bright rose, .. & $\begin{array}{l}\text { Large, culped, and perfect form. } \\
\text { Strong grower and blooming in } \\
\text { clusters. }\end{array}$ \\
\hline Angelina Bucelle,... & Rosy carmine & $\begin{array}{l}\text { Medium size, cupped, and double. } \\
\text { Moderate grower. }\end{array}$ \\
\hline Anne Beluze, ................. & Pale blush,... & Medium size, full, and compact. \\
\hline Madame Beluze. & & $\begin{array}{l}\text { A very pretty rose, and a moder- } \\
\text { ate grower. }\end{array}$ \\
\hline Apolline,,................ & Silvery rose, & $\begin{array}{l}\text { Large, cupped, and full. A vig- } \\
\text { orous grower. }\end{array}$ \\
\hline $\begin{array}{l}\text { Armosa, ....................... } \\
\text { Hermosa. }\end{array}$ & Deep pink, ... & $\begin{array}{l}\text { Medium size, cupped, and double. } \\
\text { A profuse bloomer and free } \\
\text { grower. Exquisite form, and } \\
\text { beantiful. }\end{array}$ \\
\hline Astéroide, ............ & Bright rose, .. & $\begin{array}{l}\text { Medium size, cupped, and very } \\
\text { double. Mloderate grower. }\end{array}$ \\
\hline Angustine Lelicur,.. & Rosy purple, & $\begin{array}{l}\text { Large, cupperl, and double. Y'ery } \\
\text { showy, an abundant bloomer, } \\
\text { and dwarfish habit. }\end{array}$ \\
\hline $\begin{array}{l}\text { Augustine Margat,.... } \\
\text { Thérēse Margat. } \\
\text { Mudume Murgat. }\end{array}$ & Bright red,... & $\begin{array}{l}\text { Medium size, enplped, and rery } \\
\text { double. A strong grower, fine } \\
\text { habit, fragrant, and rery pretty. }\end{array}$ \\
\hline Aurore du Guide,.... & Pur. violet, ... & $\begin{array}{l}\text { Large, } \text { lolular, and full. Mod- } \\
\text { erate grower, and occasionally } \\
\text { crimson searlet. }\end{array}$ \\
\hline Beiluté de Versailles,...... & Rosy crimson & $\begin{array}{l}\text { Latrge, full, and cupped. A mol- } \\
\text { erate grower. }\end{array}$ \\
\hline Belzunce,..... & Rosy pink,.... & $\begin{array}{l}\text { Large, compact, and very double. } \\
\text { A vigorous grower. }\end{array}$ \\
\hline Boquet de Flore,.. & Br't carmine, & $\begin{array}{l}\text { Very lare culpel, and double. } \\
\text { Profuse bloomer, fragrant, and } \\
\text { and a strong grower. }\end{array}$ \\
\hline Cardinal Fesch,.......... & Crimson,,$\ldots .$. & $\begin{array}{l}\text { Medium size. compact, and rerv } \\
\text { double. Profuse bloomer and } \\
\text { a rigorous grower. }\end{array}$ \\
\hline Celimne, ... & Delicate rose, & $\begin{array}{l}\text { Very litre, cinpled, and double. } \\
\text { Vigorous grower. }\end{array}$ \\
\hline
\end{tabular}


ROSA BOURBONIANA-Continued.

\begin{tabular}{|c|c|c|}
\hline Name. & Color. & Description. \\
\hline Cérès, ... & Rosy lilac,.... & $\begin{array}{l}\text { Very large, compact, and rery } \\
\text { double. Moderate grower, but } \\
\text { does not open well early in the } \\
\text { season. }\end{array}$ \\
\hline Cezarine Souchet,.... & Blush, .. & $\begin{array}{l}\text { Large, compact, and rery double. } \\
\text { Moderate grower. Tinged with } \\
\text { rose. }\end{array}$ \\
\hline Charlemagne, .... & Blush, ... & $\begin{array}{l}\text { Large, cupped, and very double. } \\
\text { Moderate grower. Changing to } \\
\text { pink. }\end{array}$ \\
\hline Charles Martel,... & Purple, ....... & $\begin{array}{l}\text { Medium size and full. Shaded } \\
\text { with crimson. }\end{array}$ \\
\hline Charles Souchet, .............. & $\begin{array}{l}\text { Dark rosy vi- } \\
\text { olet. }\end{array}$ & $\begin{array}{l}\text { Mectium size, cupped, and com- } \\
\text { pact. Dwarf grower. }\end{array}$ \\
\hline Chatenay, .................... & Lilac flesh, ... & $\begin{array}{l}\text { Large, full, cupped, and fragrant. } \\
\text { A vigorous grower. }\end{array}$ \\
\hline Comice de Seine et Marne, & Br't crimson, & $\begin{array}{l}\text { Medium size, cupped, and rery } \\
\text { double. A moderate grower, } \\
\text { and blooming in clusters. }\end{array}$ \\
\hline Comte de Rambuteau,.. & Dark rose, $\ldots$ & $\begin{array}{l}\text { Large, full, and compact. Dwarf- } \\
\text { ish habit, and tinted with lilac } \\
\text { color. }\end{array}$ \\
\hline $\begin{array}{l}\text { Crimson Globe,................ } \\
\text { Docteur Roques. }\end{array}$ & Pur. crimson, & $\begin{array}{l}\text { Merlium size, full, and globular. } \\
\text { Robust habit and a moderate } \\
\text { grower. }\end{array}$ \\
\hline Delille, ..... & Rosy lilac,... & $\begin{array}{l}\text { Large, compact, and very double. } \\
\text { Moderate grower. }\end{array}$ \\
\hline $\begin{array}{l}\text { Desgaches, ................. } \\
\quad \text { Gantin. }\end{array}$ & Delicate pink, & $\begin{array}{l}\text { Medium size, full, and cupped. A } \\
\text { strong grower, and blooming } \\
\text { in clusters. }\end{array}$ \\
\hline Docteur Blandin,.... & Rosy lilac, .. & $\begin{array}{l}\text { Small, globular, and very double. } \\
\text { Blooming in clusters. }\end{array}$ \\
\hline Docteur Hardouin,.... & Delic'e peach, & $\begin{array}{l}\text { Medium size, full, and cupped. A } \\
\text { moderate grower. Distinct and } \\
\text { beautiful. }\end{array}$ \\
\hline Duc de Chartres,....... & Bright rose, .. & $\begin{array}{l}\text { Very large, expanded, and full. } \\
\text { A free bloomer and robust } \\
\text { grower. }\end{array}$ \\
\hline $\begin{array}{l}\text { Duchesse de Normandie,... } \\
\text { Duchesse de Thuringe, ...... }\end{array}$ & Purplish rose, & Medium size, full, and globular. \\
\hline & & Delicately tinted with lilac. \\
\hline Trantit mo & crimson. & $\begin{array}{l}\text { A free bloomer, of dwarfish } \\
\text { habit. Changeable. }\end{array}$ \\
\hline Dupetit Thouars,.... & Dark crimson & $\begin{array}{l}\text { Large, full, and compact. A vig- } \\
\text { orous grower, and blooming in } \\
\text { clusters. }\end{array}$ \\
\hline
\end{tabular}




\section{AND FLOWER-GARDEN DIRECTORY.}

\section{ROSA BOURBONIANA-Continued.}

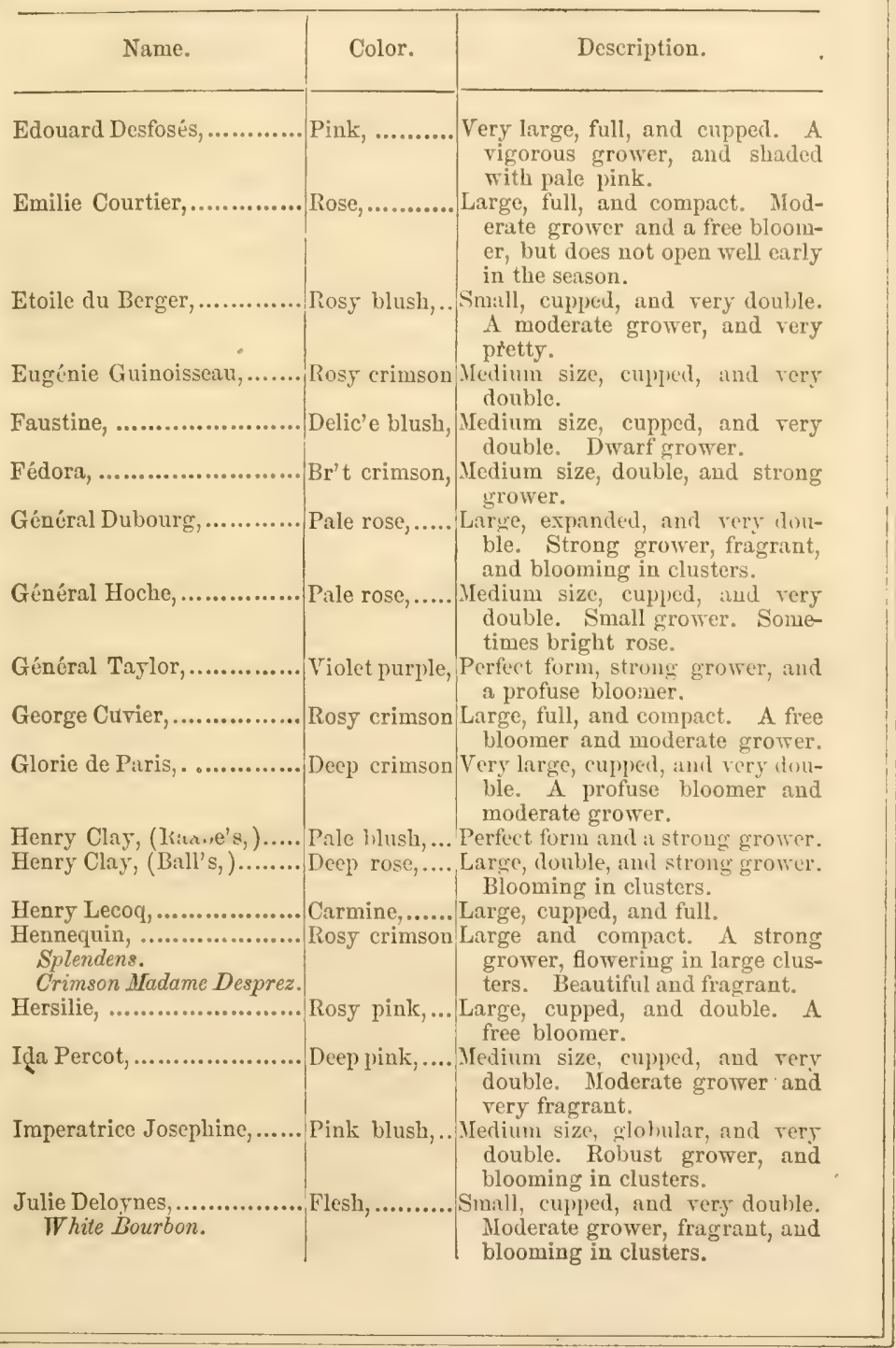


ROSA BOURBONIANA-Continued.

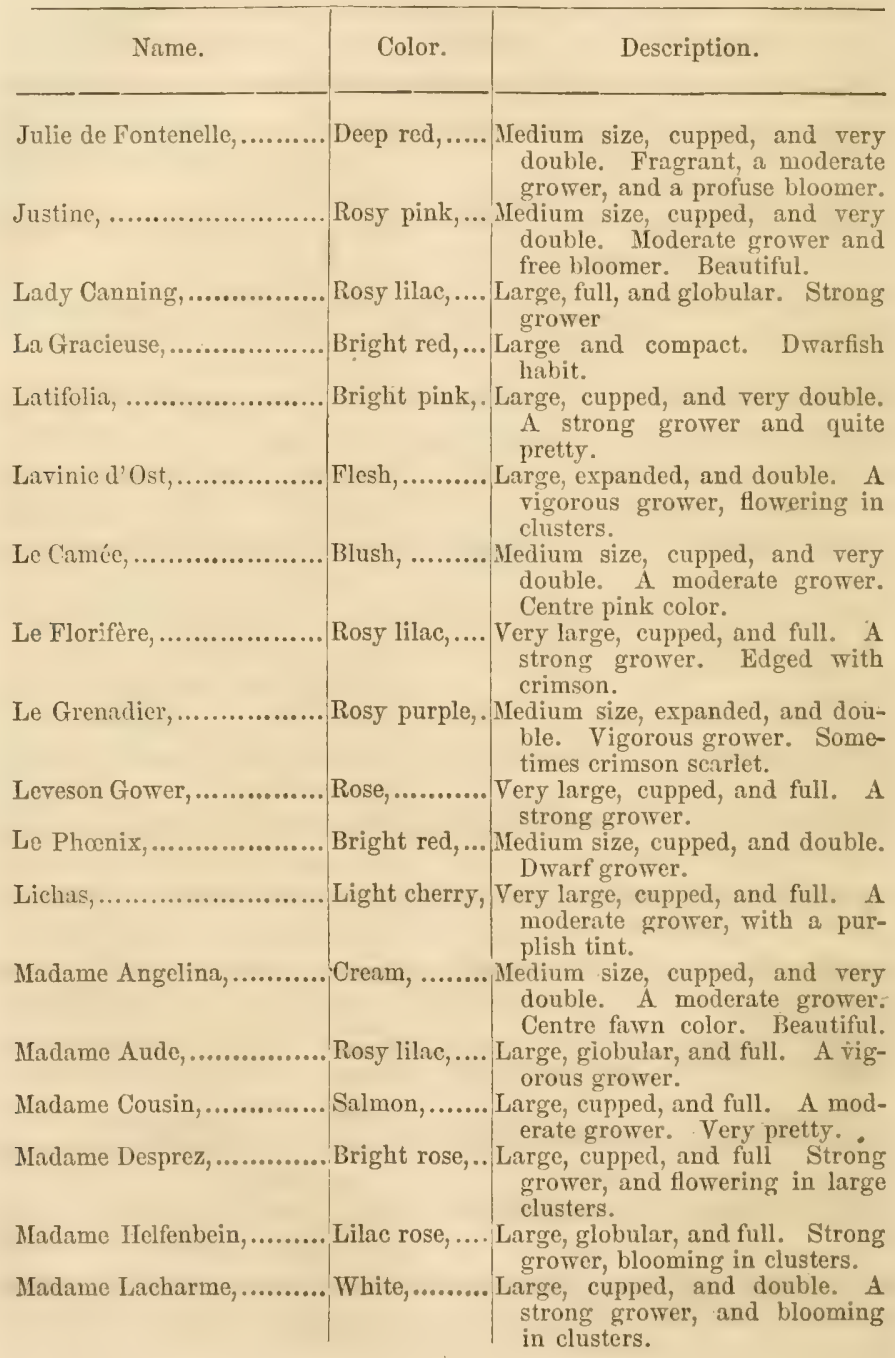




\section{AND FLOWER-GARDEN DIRECIORY.}

ROSA BOURBONIANA-Continued.

\begin{tabular}{|c|c|c|}
\hline Name. & Color. & Description. \\
\hline Madame Nérard,.... & Waxy blush; & $\begin{array}{l}\text { Large, cupped, double, and fra- } \\
\text { grant. Very perfect, and a fine } \\
\text { bloomer. }\end{array}$ \\
\hline Madame Pepin,.. & Pink, ... & $\begin{array}{l}\text { Large, cupped, and double. A } \\
\text { moderate grower. Changing to } \\
\text { blush. }\end{array}$ \\
\hline Madame Souchet,... & Blush, ,..... & $\begin{array}{l}\text { Large, compact, and double. A } \\
\text { moderate grower. Very pretty. }\end{array}$ \\
\hline Madame Tripet,.......... & Dark rose, & $\begin{array}{l}\text { Large, cupped, and double. A } \\
\text { moderate grower. }\end{array}$ \\
\hline Mademoiselle Rachel,.. & Blush, .. & $\begin{array}{l}\text { Medium size, cupped, and double. } \\
\text { A moderate grower. Tinged } \\
\text { with pink. }\end{array}$ \\
\hline Malvina, ....................... & Rosy pink, ... & $\begin{array}{l}\text { Very large, cupped, and double. } \\
\text { A moderate grower. }\end{array}$ \\
\hline Nanteau de Jeanne d'Arc, & Flesh, .. & $\begin{array}{l}\text { Medium size, cupped, and rery } \\
\text { double. Dwarfish grower, and } \\
\text { beautiful. }\end{array}$ \\
\hline Maréchal de Villars,.. & Pur. crimson, & $\begin{array}{l}\text { Very compact, good grower, and } \\
\text { a profuse bloomer. }\end{array}$ \\
\hline Margat Jeune, ....... & Rich crimson, & $\begin{array}{l}\text { Large, cupped, and a moderate } \\
\text { grower. Edges of centre petals } \\
\text { whitish. }\end{array}$ \\
\hline Marianne, .... & Rosy pink, ... & $\begin{array}{l}\text { Large, cupped, and very double. } \\
\text { Robust grower, and blooming } \\
\text { in clusters. }\end{array}$ \\
\hline Marquise d'Irry, . & Rosy pink, ... & $\begin{array}{l}\text { Very large, cupped, and full. A } \\
\text { rigorous grower, flowering in } \\
\text { clusters, and changing to lilac. } \\
\text { Jedium size cunped }\end{array}$ \\
\hline Niss Fanny, ... & Flesh,$\ldots \ldots . . .$. & $\begin{array}{l}\text { Hedium size, cupped, and full. A } \\
\text { vigorous grower, blooming in } \\
\text { clusters. Mlargin nearly white. }\end{array}$ \\
\hline Mrs. Bosanquet, & Creamy white & $\begin{array}{l}\text { Large, cupped, and double. Vig- } \\
\text { orous grower, profuse bloomer, } \\
\text { and very desirable. }\end{array}$ \\
\hline Nerine,........ . & Rosy pink,... & $\begin{array}{l}\text { Medium size, cupped, and very } \\
\text { double. Very pretty. Dwarfish } \\
\text { habit. }\end{array}$ \\
\hline Ninon de l'Enclos,.... & Rosy purple, & $\begin{array}{l}\text { Medium size, rariable, and free } \\
\text { grower. Requires to be well } \\
\text { established to show its beauty. }\end{array}$ \\
\hline Oscar Leclerc, ...... & Crimson, & $\begin{array}{l}\text { Large, cupped, and full. A ro- } \\
\text { bust grower. Shaded with dark } \\
\text { violet. }\end{array}$ \\
\hline Paul Joseph, ................... & Pur.crimson, & $\begin{array}{l}\text { Large, compact, and full. Mod- } \\
\text { erate grower, and often shaded } \\
\text { with fiery crimson. Very fine. }\end{array}$ \\
\hline
\end{tabular}


ROSA BOURBONIANA-Continued.

\begin{tabular}{|c|c|c|}
\hline Name. & Color. & Description. \\
\hline Pourpre Fafait,................ & Pale rose,..... & $\begin{array}{l}\text { Large, cupped, and double. A } \\
\text { vigorous grower, and blooming } \\
\text { in clusters. Superb. } \\
\text { Medium size, compact, and full. } \\
\text { A vigorous grower, blooming } \\
\text { in clusters. }\end{array}$ \\
\hline Pourpre de Tyre,........ & Dark crimson & $\begin{array}{l}\text { Large, full, and cupped. Robust } \\
\text { grower. Shaded with purple. } \\
\text { Variable. }\end{array}$ \\
\hline Prémices des Charpennes, .. & Lilac rose,... & $\begin{array}{l}\text { Medium size, globular, and dou- } \\
\text { ble. A vigorous grower, and } \\
\text { flowering in clusters. }\end{array}$ \\
\hline Princesse Clementine,..... & Purple, ........ & $\begin{array}{l}\text { Medium size, cupped, and full. A } \\
\text { moderate grower. Centre often } \\
\text { vivid crimson. }\end{array}$ \\
\hline Princesse de Modena,...... & Flesh, & $\begin{array}{l}\text { Medium size, finely cupped, and } \\
\text { double. A dwarf grower, and } \\
\text { tinted with pink. Very dis- } \\
\text { tinct. }\end{array}$ \\
\hline Prince Albert, (Paul's, ).... & Scar. crimson & $\begin{array}{l}\text { Large, cupped, and full. A mod- } \\
\text { erate grower. Beautiful. }\end{array}$ \\
\hline Proserpine,................ & Crimson, ..... & $\begin{array}{l}\text { Medium size, full, and compact. } \\
\text { Dwarf grower and a free bloom- } \\
\text { er. Variable. }\end{array}$ \\
\hline $\begin{array}{l}\text { Queen of the Bourbons,..... } \\
\text { Reine des Iles de Bourbon. }\end{array}$ & Fawn, ......... & $\begin{array}{l}\text { Large, cupped, and double. Free } \\
\text { bloomer and fragrant. Dwarf- } \\
\text { ish habit. }\end{array}$ \\
\hline Raymond,........... & Br't crimson, & $\begin{array}{l}\text { Medium size, expanded, and full. } \\
\text { Vigorous grower. }\end{array}$ \\
\hline Reine du Congrès, ............ & Flesh, .......... & $\begin{array}{l}\text { Medium size, full, and compact. } \\
\text { A moderate grower. Shaded } \\
\text { with pink. }\end{array}$ \\
\hline Reine des Vierges,..... & Blush, ......... & $\begin{array}{l}\text { Large and full, with flesh-colored } \\
\text { centre. A vigorous grower: }\end{array}$ \\
\hline Scipio, ........................ & Pur. crimson, & Large, double, free bloomer, and \\
\hline Souchet, ........ & Pur. carmine, & $\begin{array}{l}\text { Very large, cupped, and compact. } \\
\text { Moderate grower and fragrant. } \\
\text { Superb. }\end{array}$ \\
\hline Souvenir de Désiré,......... & Violet carm'e & $\begin{array}{l}\text { Medium size and full. A vigor- } \\
\text { ous grower. }\end{array}$ \\
\hline $\begin{array}{l}\text { Souvenir de Dumont d'Ur- } \\
\text { ville. }\end{array}$ & Rosy crimson & $\begin{array}{l}\text { Medium size, cupped, and very } \\
\text { double. Dwarf grower. Often } \\
\text { tinged with purple. }\end{array}$ \\
\hline Souvenir de la MIalmaison, & Delicate blush & $\begin{array}{l}\text { Very large, full, and compact. } \\
\text { A vigorous grower, with thick } \\
\text { petals. Very fine. }\end{array}$ \\
\hline
\end{tabular}




\section{AND FLOWER-GARDEN DIRECTORY.}

ROSA BOURBONIANA-Continued.

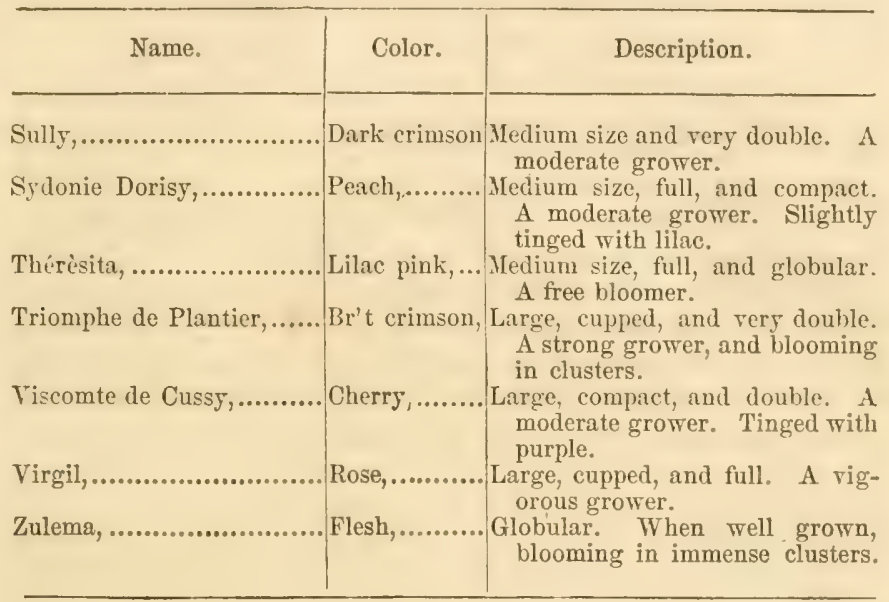

\section{Remontantes.-The Hybrid Perpetual Rose.}

This magnificient class of roses are very strong growers, generally producing very large flowers, perfect in form, combining nearly every color, and possessing a delightful fragrance. Whey are not, however, true to their name, as they generally bloom but two or three times during the season, when strong new shoots spring up. Their chief merit is the true old-fashioned character of the flowers-large and fragrant as the Damask rose. Some few are very free bloomers, and all are perfectly hardy. By eutting off the larger proportion of their first buds, and a ferv of their shoots back, they will flower in full perfection. Encouragement should be given to their growth by the addition of compost in the fall, well dug in. If their roots be watered in dry seasons, as detailed under the head of "Watering," once or twice a week, it will greatly promote both the growth and blooming of the plant. 
They require a strong and deep rich soil, and should be deprived of all superfluous wood. These may be readily propagated by either of the methods enumerated.

\begin{tabular}{c} 
Name. \\
\hline Adèle Javon, ................ \\
Admiral d'Esting, ........... \\
Alexandrine Bachmeteff,... \\
Alphonse Karr,.............. \\
Aricie, ........................ \\
Aubernon, ....................
\end{tabular}

Auguste Mlée,

Augustine Mouchelet,

Baronne de Heeckeren,

Baronne Prevost,

Calliope,

Clementine Dural,

Clementine Seringe, Pauline Plantier. Nirs. Wood.

Cœline Perpetuelle,

Commandant Fournier

Comte d'Egmont,

Comte d'Eu,

\section{Color.}

Blush ing habit. Centre rose color. Medium size, cupped, and full. A moderate grower, of erect habit. Large, full, and compact. Strong grower.

Large, expanded, and double. A moderate grower, of erect habit. Rosy lilac,... Very large, globular, and double. A strong grower.

Rosy crimson Large, cupped, and full. A moderate grower, free bloomer, and fragrant.

Light pink,... Large, full, and globular. A fine rose, and strong grower.

Bright violet, Large, full, and cupped. A very strong grower, and blooming in elusters.

Rosy pink, ... Very large, cupped, and rery double. A moderate grower, and quite showy.

Bright rose,.. Very large, full, and compact. A very strong grower.

Bright cherre Medium size, expanded, and double. Dwarf grower, of branching babit. Centre white.

Bright pink,. Medium size, full, and compact. A moderate grower, and an abundant bloomer.

Rosy pink,... Very large, expanded, and full. A strong grower, very fragrant, and shaded with lilae blush.

Delicate rose, Medium size and semi-double. Centre nearly white.

Crimson,...... Ifedium size, cupped, and very double. A dwarf grower, and very pretty.

Very large, globular, and very double. A moderate grower, and very fragrant.

Lig't carmine Very large, cupped, and double. A moderate grower, of branching habit. 
AND FLOWER-GARDEN DIRECTORY.

REMIONTANTES-Continued.

\begin{tabular}{|c|c|c|}
\hline & Color. & Description. \\
\hline Comte de Montalivet,... & Violet red,.... & $\begin{array}{l}\text { Very large, globular, and double. } \\
\text { A moderate grower. Shaded, } \\
\text { and beautiful. }\end{array}$ \\
\hline Comte de Paris,... & Rosy purple, & $\begin{array}{l}\text { Very large, double, and very fra- } \\
\text { grant. A moderate grower, and } \\
\text { flowering finely late in autumn. }\end{array}$ \\
\hline Comtesse Duchâtel,.... & Rose, & $\begin{array}{l}\text { Large, cupped, and very double. } \\
\text { A moderate grower. Occasion- } \\
\text { ally tinged with purple. }\end{array}$ \\
\hline Comtesse de Rambuteau, ...: & Peach,,$\ldots \ldots \ldots$. & $\begin{array}{l}\text { Very large, cupped, and very dou- } \\
\text { ble. A strong grower. Often } \\
\text { blooming in clusters. }\end{array}$ \\
\hline Cornet, ........ & Rosy purple, & $\begin{array}{l}\text { Very large, cupped, and double. } \\
\text { A rigorous grower, and very } \\
\text { showy. }\end{array}$ \\
\hline Docteur Marjolin,.. & Bright red, ... & $\begin{array}{l}\text { Medium size, cupped, and very } \\
\text { double. A dwarf grower, and } \\
\text { beautiful. }\end{array}$ \\
\hline Docteur Marx, ..... & Rich carmine, & $\begin{array}{l}\text { Very large, cupped, and full. A } \\
\text { moderate grower, and very fra- } \\
\text { grant. }\end{array}$ \\
\hline Duc de Alençor & Pink, . & $\begin{array}{l}\text { Medium size, globular, and full. } \\
\text { A moderate grower. Beautiful } \\
\text { in autumn. }\end{array}$ \\
\hline Duc d'Aumale,..... & Pur. crimson, & $\begin{array}{l}\text { Medium size, cupped, and double. } \\
\text { A moderate grower. A sweet } \\
\text { and beautiful rose. }\end{array}$ \\
\hline Duc d'Isly,.. & Bril. scarlet, & $\begin{array}{l}\text { Large, expanded, and semi-dou- } \\
\text { ble, A strong grower. Shaded } \\
\text { with dark velvety crimson. }\end{array}$ \\
\hline Duchesse de Galliera,...... & Bright rose, .. & $\begin{array}{l}\text { Large, cupped, and full. A mod- } \\
\text { erate grower and very fragrant. } \\
\text { Shaded with flesh color. }\end{array}$ \\
\hline Duchesse de Montpensier, ... & Delicate rose, & $\begin{array}{l}\text { Very large, full, and very fra- } \\
\text { grant. A strong grower. }\end{array}$ \\
\hline Duchesse d'Orleans,... & Laven'r blush & $\begin{array}{l}\text { Large, cupped, and full. A strong } \\
\text { grower. }\end{array}$ \\
\hline Duchesse de Praslin,... & Blush, & $\begin{array}{l}\text { Large, cupped, and full. A mod- } \\
\text { erate grower. Centre pink, and } \\
\text { very pretty. }\end{array}$ \\
\hline Duchesse de Sutherland,... & Rosy pink, ... & $\begin{array}{l}\text { Very large, cupped, and very dou- } \\
\text { ble. A strong grower. }\end{array}$ \\
\hline Earl Talbot, . & - Rosy lilac, ... & $\begin{array}{l}\text { Very large, globular, and full. A } \\
\text { strong grower. Very fragrant. }\end{array}$ \\
\hline Edouard Jess & Bright red, .. & $\begin{array}{l}\text { Medium size, cupped, and double. } \\
\text { Noderate grower, very fragrant, } \\
\text { and surrounded by a pale tint. }\end{array}$ \\
\hline
\end{tabular}


REMONTANTES-Continued.

\begin{tabular}{|c|c|c|}
\hline Name. & Color. & Description. \\
\hline Ferdinand Deppe,. & Rose,... & Large, globular, and full. A free \\
\hline Fulgorie,... & Rosy lilac,... & $\begin{array}{l}\text { Very large, cupped, and full. A } \\
\text { moderate grower, and very fra- } \\
\text { grant, with rosy crimson centre. }\end{array}$ \\
\hline Géant des Batailles,.. & Bril. crimson, & $\begin{array}{l}\text { Large, expanded, and double, A } \\
\text { moderate grower, very fragrant, } \\
\text { and beautiful. Very desirable. }\end{array}$ \\
\hline Gloire de Rosamène,.. & Crimson scar. I & $\begin{array}{l}\text { Large, cupped, and semi-double. } \\
\text { A strong grower, blooming in } \\
\text { clusters. Occasionally shaded } \\
\text { with purple and striped with } \\
\text { white. }\end{array}$ \\
\hline Grande Capitaine,... & Crimson scar. & $\begin{array}{l}\text { Medium size, cupped, and double. } \\
\text { Dwarf grower. Beautiful. }\end{array}$ \\
\hline Jacques Lafitte,... & Bright rose,.. I & $\begin{array}{l}\text { Large, expayded, and full. A } \\
\text { vigorous grower. }\end{array}$ \\
\hline Julie Dupont, ..... & Rich rose,,... & $\begin{array}{l}\text { Large, cupped, and full. A mod- } \\
\text { erate grower. Very fragrant. }\end{array}$ \\
\hline Lady Alice Peel, .. & Rosy crimson & $\begin{array}{l}\text { Large, cupped, and full. A mod- } \\
\text { erate grower, fragrant, and very } \\
\text { pretty. }\end{array}$ \\
\hline Lady Elphingstone, & Rosy crimson & $\begin{array}{l}\text { Large, cupped, and double. A } \\
\text { moderate grower. }\end{array}$ \\
\hline Lady Fordwich,. & Rich rosycrim & $\begin{array}{l}\text { Medium size, cupped, and full. A } \\
\text { moderate grower, with a pur- } \\
\text { plish tinge, changing to pale } \\
\text { rose color. }\end{array}$ \\
\hline Lady Sefton,...... & Pink, .......... & $\begin{array}{l}\text { Very large, cupped, and double. } \\
\text { A strong grower. Pretty and } \\
\text { distinct. }\end{array}$ \\
\hline Lady Stuart, .. & Delicate flesh, & $\begin{array}{l}\text { Large, cupped, and full. A mod- } \\
\text { erate grower. Beautiful. }\end{array}$ \\
\hline Lane, .. & Purplish rose, & $\begin{array}{l}\text { Large, expanded, and full. Mod- } \\
\text { erate grower. }\end{array}$ \\
\hline Laura Ramand, . & Light blush, .. & $\begin{array}{l}\text { Large, cupped, and full. A mod- } \\
\text { erate grower. Very desirable. }\end{array}$ \\
\hline La Reine,.... & Rose, ........... & $\begin{array}{l}\text { Very large, cupped, and full. Of- } \\
\text { ten shaded with lilac; occasion- } \\
\text { ally with crimson. A strong } \\
\text { grower. }\end{array}$ \\
\hline La Renoncule,... & Cherry crim., & $\begin{array}{l}\text { Yedium size, globular, and full. } \\
\text { A moderate grower, and very } \\
\text { pretty. }\end{array}$ \\
\hline Louis Buonaparte, & Deep vermil., & $\begin{array}{l}\text { Very large, cupped, and full. A } \\
\text { beautiful rose, very fragrant, } \\
\text { and a strong grower. }\end{array}$ \\
\hline
\end{tabular}


AND FLOWER-GARDEN DIRECTORY.

REIONTANTES-Continued.

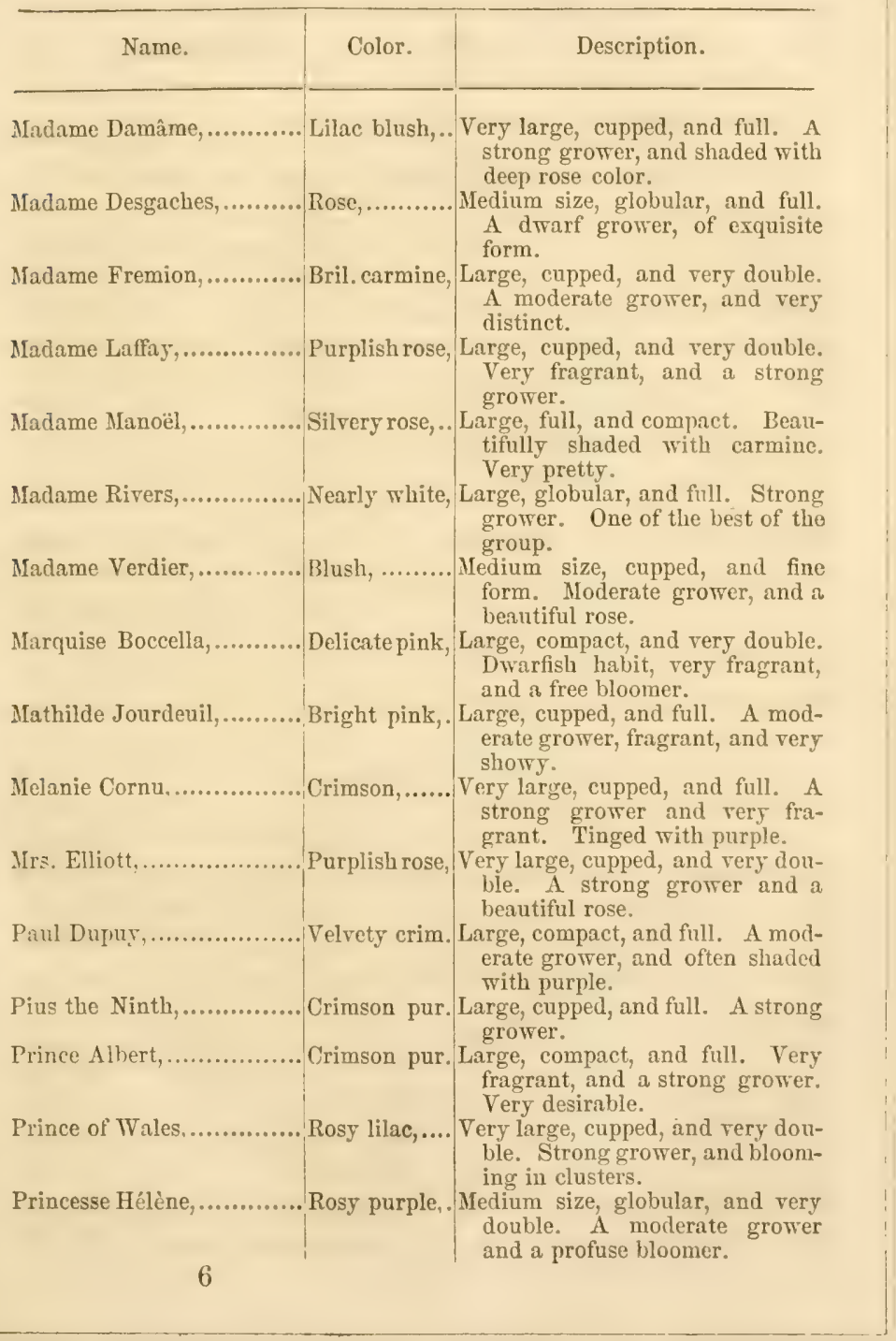


REMONTANTES-Continued.

\begin{tabular}{|c|c|c|}
\hline Name. & Color. & Description. \\
\hline Reine de la Guillotière,..... & $\begin{array}{c}\text { Dark purplish } \\
\text { crimson. }\end{array}$ & $\begin{array}{l}\text { Large, compact, and full. Strong } \\
\text { grower. }\end{array}$ \\
\hline Reine des Fleurs.... & Rosy pink, .... & $\begin{array}{l}\text { Very large, globular, and full. A } \\
\text { strong grower. }\end{array}$ \\
\hline Rivers, ...... & Rosy crimson & $\begin{array}{l}\text { Very large, compact, and full. A } \\
\text { strong grower, and blooming in } \\
\text { clusters. }\end{array}$ \\
\hline Robin Hood,....... & Bril. cherry,. & $\begin{array}{l}\text { Large, globular, and full. Very } \\
\text { fragrant, and a strong grower. }\end{array}$ \\
\hline Sixth of June, ............ & Bright rose, .. & $\begin{array}{l}\text { Medium size, compact, and very } \\
\text { double. Dwarfish habit. }\end{array}$ \\
\hline Standard of Marengo, ..... & Bril. crimson, & $\begin{array}{l}\text { Large, cupped, and double. A } \\
\text { modexate grower and very dis- } \\
\text { tinct. }\end{array}$ \\
\hline William Jesse,..... . & Lig't crimson & $\begin{array}{l}\text { Very large, cupped, and rery dou- } \\
\text { ble. Aloderate grower, tinged } \\
\text { with purple. }\end{array}$ \\
\hline William Griffith,... & Pale rose,... & $\begin{array}{l}\text { Large, compact, and full. Petals } \\
\text { very thick, and a strong grower. }\end{array}$ \\
\hline
\end{tabular}

\section{PERPETUAL DAMASK ROSES.}

Some fer years since, this family of the rose was quite limited, comprising a favorite old group more remarkable for the delicious fragrance of their flowers than for their size or beauty of form; but, from hyloridization, have now become so extensive, raried in color, and character, that for fragrance, color, and perfection of their bloom, they eannot be surpassed. Many roses are sold under this head which fall far short of what their name would imply, blooming but once, (in June,) and, with all the encouragement which may be given them, they sellom produce the second bloom. They are quite hardy, and make fine standard plants. The culture recommended for the Remontantes is applicatle to this class of the rose. They may be propagated by either of the 


\section{AND FLOWER-GARDEN DIRECTORY.}

methods designated. In rooting by layers, however, they will be found to require two years to form rootlets. Budding and grafting are preferable, and by fir the easiest and quickest method for this family.

\begin{tabular}{|c|c|c|}
\hline Name. & Color. & Description. \\
\hline ingelina, & Crimson pur. & Medium size, expanded, and full. \\
\hline Intinous, ... & Pur. crimson, & $\begin{array}{l}\text { Large, cupped, and full. Perfect } \\
\text { and fragrant. }\end{array}$ \\
\hline $\begin{array}{l}\text { Belle Faber,... } \\
\text { Grande. }\end{array}$ & Rosy crimsou & Very large, globular, and full. \\
\hline Soricac & Salmon, & Yredium size cunped and full. \\
\hline $\begin{array}{l}\text { Madame Ferr } \\
\text { Perpetual Po }\end{array}$ & & $\begin{array}{l}\text { Medium size, cupped, and full. } \\
\text { Very pretty, free bloomer, and } \\
\text { fragrant. }\end{array}$ \\
\hline $\begin{array}{l}\text { Billiard, .................... } \\
\text { Georgina. }\end{array}$ & Rosy pink, . & $\begin{array}{l}\text { Large, expanded, and double. A } \\
\text { dwarf grower, free bloomer, and } \\
\text { fragrant. }\end{array}$ \\
\hline Claire du Châtelet,. & Rosy pink, & $\begin{array}{l}\text { Hragrant. } \\
\text { Medium size, cupped, and very } \\
\text { double. Free grower. }\end{array}$ \\
\hline de Berar & Ros: & Medium size, culpred, and full. \\
\hline $\begin{array}{l}\text { Crimsol } \\
\text { Rose } \\
D^{\prime} \text { Ange }\end{array}$ & & $\begin{array}{l}\text { Large, cupped, and full. Very } \\
\text { fragrant. }\end{array}$ \\
\hline & 10 & $\begin{array}{l}\text { Large and double. A free bloom- } \\
\text { er and very fragrant. }\end{array}$ \\
\hline D'Esqu & Bright rose, & $\begin{array}{l}\text { Large, compact, and full. Showy } \\
\text { and very fragrant. }\end{array}$ \\
\hline & Rosy & $\begin{array}{l}\text { Large, expanded, and very double. } \\
\text { Very fine foliage. }\end{array}$ \\
\hline Desdemona,.. & Rosy purple, & $\begin{array}{l}\text { Small, cupped, and donble. Very } \\
\text { fragrant and distinct. }\end{array}$ \\
\hline Dexil de Dumont d'Urville & Pur. crimson, & $\begin{array}{l}\text { Medium size, cuppert, and double. } \\
\text { Spotted with chocolate color. }\end{array}$ \\
\hline Ducluesse de Rohan, & Rosy & $\begin{array}{l}\text { Large, compact, and full. Tinged } \\
\text { with lilac. Very fine. }\end{array}$ \\
\hline Earl of Derby,... & & Large, cupped, and full. Tinged \\
\hline Eliza Balcombe,. & & $\begin{array}{l}\text { Smill, cupped, and very double. } \\
\text { Centre pinkish biush. }\end{array}$ \\
\hline Grande et Belle, & Purplish rose, & $\begin{array}{l}\text { Very large, globular, and double. } \\
\text { Perfect form. }\end{array}$ \\
\hline Indigo,.. & Dark purple, & $\begin{array}{l}\text { Large, expanded, and double. } \\
\text { Very distinct. Sometimes tint- } \\
\text { ed with rosy crimson. }\end{array}$ \\
\hline & & $\begin{array}{l}\text { Medium size, expanded, and rery } \\
\text { double. A profuse bloomer, and } \\
\text { shaded with lilac. }\end{array}$ \\
\hline
\end{tabular}




\section{PERPETUAL DAIIASK ROSES-Continued.}

\begin{tabular}{|c|c|c|}
\hline Name. & Color. & Description. \\
\hline Jeanne Hatchette,... & Lilac rose, .... & $\begin{array}{l}\text { Very large, globular, and very } \\
\text { double. Fragrant, and a strong } \\
\text { grower. }\end{array}$ \\
\hline Josephine Antoinette,.. & Pink'h blush, & $\begin{array}{l}\text { Large, globular, and full. Very } \\
\text { fragrant, and desirable. }\end{array}$ \\
\hline La Capricieuse,..... & Crimson,....... & $\begin{array}{l}\text { Medium size, double, and very } \\
\text { fragrant. }\end{array}$ \\
\hline Lady Seymour,.. & Dark rose,,... & $\begin{array}{l}\text { Medium size, full, and fragrant. } \\
\text { Occasionally spotted with blush. } \\
\text { Very pretty. }\end{array}$ \\
\hline $\begin{array}{l}\text { La Mienne, .................... } \\
\text { Flon. } \\
\text { Gloire des. }\end{array}$ & Rosy erimson & $\begin{array}{l}\text { Large, compact, and very double. } \\
\text { Erect habit and dense foliage. }\end{array}$ \\
\hline La Miniature,.......... & Pale rose,,$\ldots$ & $\begin{array}{l}\text { Small, rery pretty, and a profuse } \\
\text { bloomer. }\end{array}$ \\
\hline Laurence de Montmorency, & $\begin{array}{l}\text { Glossy rosy } \\
\text { lilac. }\end{array}$ & $\begin{array}{l}\text { Large, cupped, and full. Very } \\
\text { fragrant and desirable. }\end{array}$ \\
\hline Louis Philippe, & Crimson, ..... & $\begin{array}{l}\text { Large, expanded, and double. } \\
\text { Very rich. Shaded with dark } \\
\text { purple. }\end{array}$ \\
\hline Marjolin,... & Blush, ......... & $\begin{array}{l}\text { Large, cupped, and full. Centre } \\
\text { rosy. }\end{array}$ \\
\hline Minerva, .. & Posy pink, ... & $\begin{array}{l}\text { Large, compact, and full. Lilac } \\
\text { tinted, fine habit, and very } \\
\text { fragrant. }\end{array}$ \\
\hline $\begin{array}{l}\text { Mogador, .............. } \\
\text { Crimson Superb. }\end{array}$ & Bril. crimson, & $\begin{array}{l}\text { Large, cupped, and full. A mod- } \\
\text { erate grower, shaded with rich } \\
\text { purple, and very superb. }\end{array}$ \\
\hline $\begin{array}{l}\text { Palmyre, ................. } \\
\text { Blush Perpctual. }\end{array}$ & Blush, ......... & $\begin{array}{l}\text { Medium size, compact, and full. } \\
\text { Centre rosy pink. }\end{array}$ \\
\hline $\begin{array}{l}\text { Panaché de Girardon,. } \\
\text { Striped Perpetual. }\end{array}$ & & $\begin{array}{l}\text { Hedium size, cupped, and double. } \\
\text { Striped with red. }\end{array}$ \\
\hline Pontuiee, ........................ & Bright rose,.. & $\begin{array}{l}\text { Medium size, expanded, and rery } \\
\text { double. Spotted with white. }\end{array}$ \\
\hline Princesse Royale, ........... & Bright crim., & $\begin{array}{l}\text { Small, cupped, and full. Rather } \\
\text { delicate. }\end{array}$ \\
\hline Pulchérie, .... & Deep crimson & $\begin{array}{l}\text { Large, cupped, and double. Tint- } \\
\text { ed with purple. }\end{array}$ \\
\hline Requien,........ & Blush pink,.. & $\begin{array}{l}\text { Very large, cupped, and rery dou- } \\
\text { ble. Blooms finely late in the } \\
\text { season. }\end{array}$ \\
\hline Saint Fiacre,,...$\ldots \ldots \ldots \ldots \ldots$ & Violet \& crim. & $\begin{array}{l}\text { Medium size, cupped, and double. } \\
\text { Marbled. }\end{array}$ \\
\hline $\begin{array}{l}\text { Striped Crimson Perpetual, } \\
\text { Captain Rēenard. }\end{array}$ & Rosy pink, ... & $\begin{array}{l}\text { Larce, cupped, and rery doulle. } \\
\text { Occasionally striped, but more } \\
\text { frequently only mottled with } \\
\text { white. }\end{array}$ \\
\hline
\end{tabular}


PERPETUAL DAMASK ROSES-Continued.

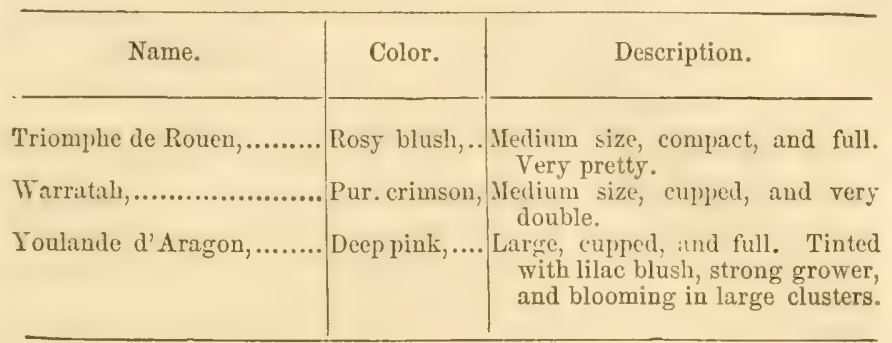

rosa Michrophylila.-The Shall-Leaved Rose.

The plants of this family are very beautiful, being more distinct both in their flowers and habit than either of the other classes. They are perfectly hardy, delighting in a dry, rich, warm, sandy soil. Several varieties of this group are well adapted for covering rerandahs, buildings, \&c., combining many different colors. Some possess a delightful fragrance, and, being generally strong growers, may be trained in any desired form. They may be propagated by either of the methods enumerated, but layering is deemed preferable, as being the safest and quickest mode for securing handsome and well-formed plants.

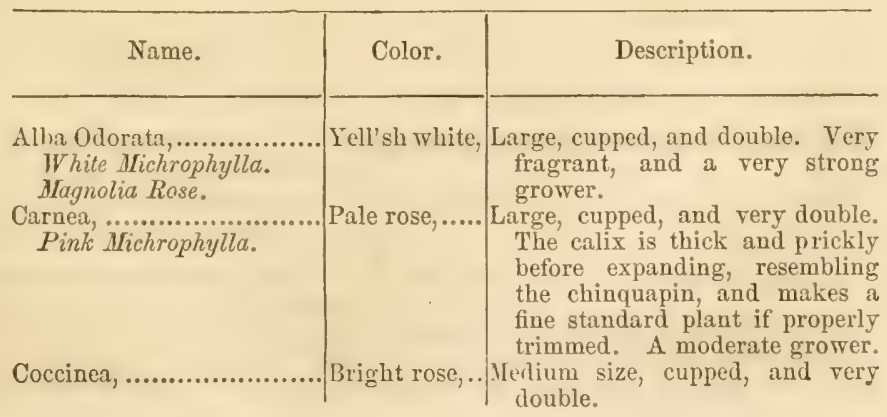


ROSA MICHROPHYLLA-Continued.

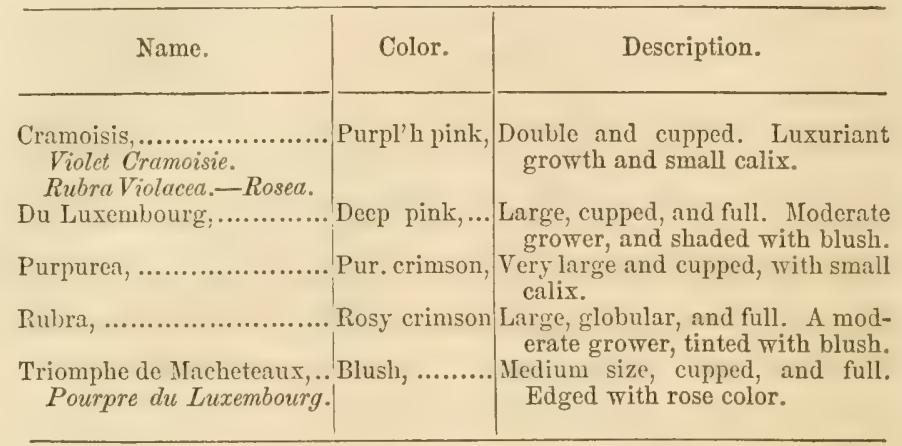

rosa moschata.-The Musk-scented Rose.

This family received its name from the peculiar, and to many disagreeable, odor which they exhale when in flower, and embrace single, semi-double, and a few very double varieties. They are more or less teuder, and, in bleak and unsheltered situations, should be protected by coverings of straw or the branches of evergreens. The treatment recommended for the Noisettes is adapted to this class of the rose. Being rapid growers, they make handsome pillar roses.. They require a dry situation and rich soil.

\begin{tabular}{|c|c|c|}
\hline Name. & Color. & Description. \\
\hline Herbemonth's Musk Cluster & Pure white, .. & Very large and double. Bloom- \\
\hline Nivea, .......................... & White,... & $\begin{array}{l}\text { Large, cupped, and single. A } \\
\text { strong grower, and shaded with } \\
\text { rose color. }\end{array}$ \\
\hline Princesse de Nassau, ......... & Yel'sh white, & $\begin{array}{l}\text { Very double and cupped. Par- } \\
\text { takes strongly of the musk odor. }\end{array}$ \\
\hline $\begin{array}{l}\text { Ranunculus Musk Cluster, } \\
\text { New Double Musk Cluster. }\end{array}$ & Pure white,.. & $\begin{array}{l}\text { Perfectly double, but does not } \\
\text { open well in moist weather. }\end{array}$ \\
\hline
\end{tabular}




\section{AND FLOWER-GARDEN DIRECTORY.}

\section{EXPLANATION OF TERMS}

EMPLOYED IN DESCRIBING THE ROSES ENUMERATED.

Having used certain terms in deseribing the plants enumerated in the preceding pages, we deem it due to the general reader that we should explain,' viz:

Small, signifying from $1 \frac{1}{2}$ to 2 inches in diameter.

$\begin{array}{llll}\text { Medium size, " } & 2 \text { to } 2 \frac{1}{2} & \text { " } \\ \text { Large, } & \text { " } & 2 \frac{1}{2} \text { to } 3 \frac{1}{2} & \text { " } \\ \text { Very large, } & \text { " } & 3 \frac{1}{2} \text { to } 5 & \text { " }\end{array}$

Single.-Such as have but one row of petals.

Semi-double.-Having from two to five rows of petals.

Double.-Having more than fire rows of petals, yet showing the stamens in the centre of the flower.

I rry double.-Possessing a sufficient number of petals to hide the central stamens.

Full.-Where the petals are placed closely together.

Globular.-Assuming that form, and remaining closed, or nearly so, til? nearly full blown.

Cupped.-Where the outer petals stand erect or are incurred. The inner petals being smaller than the outer, forming a hollow in the centre like a cup.

Compact.-Where the petals are stiff and upright, the centre being nearly level with the circumference; more frequently above than below it.

Expanded.-Where the outer petals, instead of being ereet, lie nearly horizontal, generally turning back upon the flower-stalks in the last stage.

Perfect, fine, good, and becutiful.-Where the rariety or form are very elegant.

Dwarf.-Humble or low growth.

Erect.-Whose shoots rise perpendicular.

Branching.-Where the shoots have the tendency to branch from the centre of the plant.

Moderate.-Such as form neat and compact bushes.

Strong and vigorous. - Such as are rapid and robust growers.

Standards. -From three to five feet in height. 


\section{SELECT LIST OF ROSES.}

In the foregoing lists, we have embraced such only as we feel assured, with proper care and attention, will prove every way worthy of cultivation. We might readily have extended the same by hundreds, but as we propose to point out to the Amateur such plants only as are worthy of a place in every collection, we have confined ourself to those enumerated. There are several recent additions, whose merits are yet to be tested. Among such a number of beautiful varieties, where there are so many lovely forms and colors, dazzling the eye and attracting the senses, the inexperienced Amateur, no doubt, will find it impossible to choose. In order to assist him in making a judicious selection of plants from the multitude which compose the groups and subdivisions of the rose family, we have carefully selected the following choice varieties from those enumerated, which will be found to possess, in an eminent degree, the beauty, fragrance, and varied attractions of the rose, viz:

\section{MULTIFLORA ROSES.}

Laura Daroust, deep pink to pure white. Russelliana, crimson.

\section{MOSS ROSES.}

Crested Provins, rosy pink.

Crimson Pompon, rosy violet.

Laffay's Perpetual White Moss, white. Rouge, crimson.
Panachée Pleine, white or flesh. Princesse Adelaide, rosy blush.

\section{NOISE'TTE ROSES.}

Aimée Vibert, pure white.

Cloth of Gold, light yellow.

Comtesse Odoisee, pink.

Conque de Venus, creamy white.

Dona Maria, rose.

Fellenburg, pale red.
Jaune Desprez, rosy buff.

Lamarque, greenish white.

La Pactole, pale sulphur.

Ophire, redish copper.

Solfatare, sulphur yellow.

Triomphe de la Diuchère, pale rose. 


\section{TEA-SCENTED ROSES.}

Adam, deep blush.

Bougère, salmon.

Caroline, rosy pink.

Clara Sylvain, pure white.

Devoniensis, creamy white.

Eliza Sauvage, creamy yellow.
Gobault, rosy blush.

Jaune Panaché, light straw.

Joséphine Malton, creamy white.

La Sylphide, creamy white.

Madame Desprez, pure white.

Safrano, saffron.

\section{BENGAL CHINESE, OR DAILY ROSES.}

Archduke Charles, bright rose.

Beau Carmin, dark crimson purple.

Carmin d'Yebles, bright carmine.

Cramoisie Supérieur, velvety crimson.

Eugène Beauharnais, rich crimson.

Hortensia, blush pink.
Icterose, creamy white.

Madame Breon, bright rose.

Madame de Crequi, blush.

Mellez, pure white.

Reine de Lombardie, bright rosy red. Virginale, blush.

MUNIATURE ROSES.

Alba, pure white.

La Miniature, bright pink.

\section{BOURBON ROSES.}

Armosa, deep pink.

Boquet de Flore, bright carmine.

Crimson Globe, purplish crimson.

Dupetit Thouars, dark crimson.

Hennequin, rosy crimson.

Julie Deloynes, flesh.
Madame Lacharme, white.

Mrs. Bosanquet, creamy white.

Paul Joseph, purplish crimson.

Queen of the Bourbons, fawn.

Souvenir de la Malmaison, del. blush.

Scipio, purplish crimson .

\section{HYRRID PERPETUAL ROSES.}

Aubernon, rosy crimson.

Clementine Seringe, rosy pint.

Commandant Fournier, crimson.

Comte de Montalivet, violet red.

Comtesse de Rambuteau, peach.

Docteur Marx, rich carmine.
Duchesse de Praslin, blush.

Géant des Batailles, bril. crimson.

Grande Capitaine, crimson scarlet.

Lady Alice Peel, rosy crimson.

La Reine, rose.

Prince Albert, crimson purple.

\section{PERPETUAL DAMASK ROSES.}

Belle Faber, rosy crimson.

Bernard, salmon.

Claire du Châtelet, rosy pink.
Josephine Antoinette, pinkish blush. Laurence de Montmorency, glossy rosy lilac. 
Deuil de Dumont d'Urville, purplish Minerva, rosy pink. crimson.

Eliza Balcome, white. Isaure Lablée, pink.

Requien, blush pink.

Triomphe de Rouen, rosy blush. Youlande d'Aragon, dark pink.

\section{SMALL-LEAVED ROSES.}

Alba Odorata, yellowish white.

Carnea, pale rose.

\section{MUSK-SCENTED ROSES.}

IIerbemonth's MIusk Cluster, white. Princesse de Nassau, yellowish white.

\section{MILDEW.}

Where extremes of temperature prevail, this disease is sure to make its appearance, geuerally in July and August. The following mixture will prove an effective remedy for its removal. To one-quarter of a pound of unslacked lime, add one pound of flourof-sulphur, poring two gallons of boiling water over the same, and cover close for one hour. Stir the whole well together, until the sulphur sinks to the bottom. I Let it settle, and pour off for use. One quart of this mixture to one gallon of water will be sufficiently strong for this purpose. Apply by the syringe.

\section{DESTRUCTIVE INSECTS.}

Among the most injurious and troublesome of all insects, against whose depredations the Amateur has to contend, are the Rose-bug and Rose-wons. Unlike some of his other unwelcome annual visitors, they can only be removed by hand picking. The former will be found upon the blossom as soon as it expands; the latter on the bud.

The Green-fLy is also very troublesome, but may be readily exterminated by a few applications, with the syringe, of tobaceowater or whale-oil soap-suds, in the evening, and with pure water again on the following morning. If the latter be omitted, the 
remedy may prove more destructive than the disease. Onehalf ounce of whale-oil soap to one gallon of water will be sufficiently strong for this purpose. If tobacco-water be used, two ounces of tobaceo, boiled in one gallon of water, and allowed to cool, will be effective. IItving rid the plants of these troubleane pests, stir the soil about their roots, which will tend to refresh them.

The SLCi, unlike the bug and the worm, confines his ravages $\left.t_{1}\right)$ the foliage of the plant, aud will destroy nearly every leaf if not (becked in his devastations. Whate-oil soap-suds, applied by the syringe or watering-pot, over the foliage of the plaut, will effect this nlject. They are also fond of the ends of young shoots of some other plants, (Caruations, \&e.,) and are very troublesome where they abound. Where the above remedy is not at hand, if a hair-peneil, dipped in linseed-oil, be drawn around the shoots of the plants, once in two days, the Slug will not attack them. Few insects can endure oil, and the smallest quantity generally will stop their ravages.

The FLY is also very destructive in some localities. During the months of July and August, the tops of the young shoots of roses are frequently seen to droop. This is caused by the ravages of a fly. As soon as perceptible, the ends of the shoots should be cut off from eight to ten inches, when the Grun, its offspring, will be found imbedded in the centre. The Fly is supposed to lay its eggs on some of the young wood near the grounil, in Mity or June. If the shoots attacked are not cut off anil destroyed, the grub will make his escape, under a leaf, near the tun, make for the ground, and live to repeat his depredations the ensuing year.

\section{PROTECTING TENDER ROSES.}

In covering roses for the winter, be careful not to injure them by binding whatever is used for the purpose too tight about the branches, for it is not warmth you wish to impart, but to afford 


\section{2}

\section{'THE AMATEURS' GUIDE}

them protection against sudden changes of temperature, espec1ally against alternating freezing and thawing. Branches of evergreens should be used for this purpose, and are preferable to straw. If the latter be used, and put on closely, it is very apt to sweat, which should be avoided. In order to secure partial access to the air and light, they should be placed moderately loose over the plant, yet sufficiently secure to prevent them from being displaced by high winds.

\section{GRAFTING-WAX.}

To two ounces of bees-wax add one ounce of beef-tallow, four ounces of common pitch, and twelve ounces of Burgundy pitch. Melt all together, and apply when in a fluid state with a brush. Be careful not to apply the same when too hot. 


\section{GARDEN PLANTS.}

\section{BOX EDGING,}

Has a beautiful appearance if kept neatly trimmed and regular, especially in winter, and adds much to the beauty of the garden. The dwarf variety (Buxus sufferticosA) is generally employed for this purpose, and may be readily propagated from cuttings or slips, early in the spring or October. The latter is preferable, for, if ordinary care be taken in planting, it will be sufficiently rooted to encounter the scorching rays of the sun, which, in dry seasons particularly, burns and frequently destroys that set out in * the spring. Any common garden soil will answer for this purpose. If to be raised from cuttings, in the spring, they should be planted in a bed to themselves, where they can have shade and waterings; for, when planted as edging, if some should fail to grow, the same becomes uneven and full of gaps, and will be found rather difficult to get in good shape again. To perform the operation, the margin of the beds having been properly leveled, excavate a drill from four to six inches deep, according to the length of the cuttings or slips to be inserted, and, if the former, place them within half an inch of each other, in alternate rows, gently pressing them in an upright position. Draw the soil up around them, and moderately press the same. To form a neat edging, the operator should be careful to have the cuttings or slips equally distributed. In planting slips, the alternate row may be dispensed with; in which case, the tops should be slightly pressed into each other, so as to form an unbroken and even surface. Both cuttings and slips should be deprived of all leaves as far up from the bottom as they are to be inserted in the soil, which may be easily effected by drawing them gently through the 
hand. When inserted, draw the earth up nearly to the top of the slips, pressing neatly and closely the same, and cut any inequalities of the top even. Give moderate waterings in dry weather during the first season after planting. Where parallel lines are to be set out, a garden-line should be used to lay off the ground. In trimning, the month of October should be selected.

\section{CARNATION PINKS.}

These beautiful plants are very desirable acquisitions to the garden, and when well grown, the beauty and odor of their flowers cannot be surpassed. They should have a rich deep soil, and may be propagated from seed, pipings, or layers. The latter will be fouud preferable to either of the former and the most successful method. In layering, the lowest young shoots should be selected. Pull off the under leaves and cut a small slit or gash upward at a joint on the under side Lay that portion in the earth two or three inches deep, as the plant will admit, and peg the shoot down with a small hooked stick, keeping the top upright above ground and the slit part open, bending it carefully so as not to break at the incision. Press the soil gently around with the fingers, and cut off about half an inch of the top of the shoot. The sap will granulate at the wound and throw out roots, and, if kept moderately moist, in about four or six weeks, they will be sufficiently rooted to sever from the parent plant, when they may be transplanted or permitted to remain until the ensuing spring. In the latter case, they should be protected with leares, straw, or the branches of evergreens. If desired, they may be planted in pots as soon as they have taken root and placed in the pit, where they can be kept with perfect safety, if air be given them in mild weather. As soon as the plants are done flowering, is the proper time to select for this purpose.

The operation of piping consists in planting detached parts of the young shoots, which either pull out of the pipe or cut 
off below in proper lengths. Pull off the under leaves and cut each shoot clean to a lower joint, eutting that part even at the end, and shorten the top leaves even. Place them in a bed, border, or pots of good soil, an inch or two apart, inserted down to their leaves. Water and shade from the sun. If covered elose with hand-glasses, they will not only root sooner, but much more effectively. The month of July should be selected for this pur. pose. In a month or sis weeks they will be sufficiently rooted for transplanting.

\section{CHRYSANTHEMUM.}

This old and much-esteemed fall flower, blooming when most of the summer bloomers have taken their leave, has been greatly improved in appearance by hybridization. So unlike and distinct are some of the new varieties as to be scarcely recognised as the same flower. Many of the dwarf varieties resemble the quilled China Asters. They are all perfectly hardy, and may be propagated by any of the ordinary methods. The dwarf varieties, occupying a very small space, well merit a place in every collection of plants. If the tops of the strongest shoots be selected for cuttings, in April or May, and planted in the open ground, their tops pinched off to within five or six joints, and kept moderately watered, they will form handsome and strong-flowering plants. Being stroug feelers, they should have a rich strong soil to enable them to flower in perfection. As soon as the plants show their flower-buds, they should be securely staked. If one-third of their buds be pinched off, the remainder will more than compensate for their abscence.

\section{DAHLIA.}

The Dahlia, particularly when planted early in the season, is frequently attacked, and their beauty greatly impaired, by the red 
spider; their foliage being often entirely destroyed by these troublesome insects. The following mixture will serve to rid the plants of this pest of the garden. To a half pound of the flour-ofsulphur add a half pound of unslacked lime, mix well together in three pints of water, and boil for ten minutes, stirring it well when boiling. Remove from the fire, and, when settled, bottle for use. To one part of this mixture add two parts of water, and apply the same to the under part of the leaves by the syringe, until the inseet has disappeared. The young shoots are also frequently attacked by earwigs. If any common oil be applied to the stalk near the ground, it will generally serve to free the plant from these voracious insects. If liquid manure be occasionally applied to Dahlias, it will add to the profusion and beauty of their bloom.

\section{GERANIUMS}

This family of plants, with proper culture, will amply repay in the profusion and beauty of their bloom the labor bestowed upon them. Very exciting composts should not be used for these plants, for where they make a rapid growth, they do not produce their bloom in the same perfection as when kept within proper bounds. They should have a soil composed of one-lialf pure loan, one-fourth leaf-inould, and one-fourth well-rotted manure, well incorporated together. Excessive moisture is very injurious, causing the leaves to fall, and gives the plant the appearance of mildew. When crowded, some of the lateral branches should be thinned out. Geraniumns may be propagated from seed, cuttings, or slips of the root. If placed in a shady and dry position, cuttings will readily root in three or four weeks. Plant out in June.

HYDRANGEA.

These beautiful and showy plants may readily be propagated from cuttings, layers, or divisions of the root, in the ordinary 
manner. They delight in a rich loamy soil, and should be planted in a shady and moist situation. They are quite hardy. The wood should be quite ripe to insure success by either method of propagation. The colors of these plants may, to a certain extent, be varied by artificial means. The rose-colored variety, (Hrdiangea nontensis,) by means of a mixture of iron with the soil they grow in, may be changed to a blue tint. To attain this result, iron-filings, or the refuse which accumulates on a grindstone, should be employed.

\section{LILIES.}

This large and handsome family of flowering bulbs, delighting in a soil composed of well-rotted manure, leaf-mould, and sandy loam, in equal parts, may be propagated generally from offsets, and some varieties from seed. Most of the species are quite hardy, but if covered with well-rotted manure, will bloom much stronger. They generally flower in July and August, and should be well watered in dry seasons till done blooming. When a disposition for dormancy is evinced, watering should be dispensed with; and, if in pots, the stalks cut down, and the bulbs remover to some place protected against frost, there to remain until the season for flowering. As soon as the foliage begins to decay, the roots may be divided. If delayed until the foliage commences to grow, the bloom will be greatly weakened.

\section{PETUNIAS.}

Blooming from June to November, and every shoot being laden with flowers, the Petunia should have a place in every garden. Some varieties, when once established, will sow themselves rather too plentifully over the garden. The better sorts should only be cultivated, and will amply repay, in the beauty and profusion of their flowers, the labor bestowed upon them. They can easily 
be propagated from cuttings, from June to October, and, if planted in the pit, or a warm shady border, under hand-glasses, will root quite freely. If desired for planting out the ensuing spring, they should be struck in September, and when sufficiently rooted, potted off and placed in the pit to be kept through the winter. They should have a rich sandy loam.

\section{VERBENAS.}

The graccful habit, brilliancy of colors, and the long continuance of their bloom, render these beautiful plants a valuable acquisition to the Flower-garden. They should never be staked, as it destroys the beauty of the plant. When permitted to run on the ground, if the soil be moderately good, they will generally propagate themselves to a very great extent, nearly every eye in contact with the soil taking root and forming handsome and strong-blooming plants. When attacked by the green-fly or miluew, the remedies recommended for roses should be applied. They may readily be propagated from cuttings in the ordinary manner. Some varieties will live through the winter if covered with straw or litter, but they do not do as well as young plants set out in the spring.

\section{YUCCA:}

The beauty of these plants when in flower must be seen to be properly appreciated. They are perfectly harly, delighting in a rich light soil, and may readily be propagated by dividing the roots in April or May. Retaining their decp green foliage through the winter, they form very ormamental and desirable plants, and merit a place in every collection.

\section{HOUSE PLANTS IN WINTER.}

In taking plants in the house, the object is twofold, protection against frost and to lawe them bloom in winter. Plants designed 
for winter flowering, should be potted off in summer, placed in a shady position, and permitted to rest, by which treatment they will gain streugth. Plints which bloom in summer must rest in winter, and when not allowed to bloom in summer, become artificially changed. When housed, the essential rexuisites to enable them to bloom well are light, moisture, temperature, and cleanliness.

The plants should be placed in such a position where each portion can receive its due share of light, or they will grow straggling, weak, and out of shape, by bending toward the light.

In order to secure a proper drainage, the pots should have pieces of broken flower-pots, charcoal, fc., placed in the bottom. This should be done particularly for geraniums and roses.' Different plants require different degrees of moisture. The aquatic plants require an abundance, while others should only have a sufficiency to keep the soil moderately moist. Give water in proportion to the wants of the plant.

Sudden changes of temperature should be particularly guarded against. Too nuch heat destroys the foliage, as well as the buds. In open weather, give fresh air to the plants, and keep the soil loosened in the tops of the pots.

Should the green-fly make his appearance, place the plants in such a situation that they can be fumigated with tobacco-smoke. Twenty minutes will serve for this purpose. Brush the plants gently, cleanse the pots, and give fresh air. The tops of the plants should be sprinkled three times a week, for it not only serves to keep them clean, but greatly strengthens them. If these precautions be adhered to, the bloom will amply repay the labor bestowed upon them.

Where plants are housed merely for protection, they may be safely kept by placing them in any ordinary room, having a sufficiency of light, and in which the temperature does not fall below $40^{\circ}$. In open weather, give moderate waterings. More plants are lost in house culture from excessive heat and the want of fresh air and light than those lost by other causes. 


\section{BULBS IN POTS}

The soil used for this purpose should be composed of leaf-mould, loam, and well-rotted manure, in equal parts. When the pots are filled, place the bulb in the centre, and gently press into the soil until it becomes nearly covered. Place in a cool situation to assist their rooting. If deprived of light, they will root more readily. If moderately watered when planted and placed in a tolerably damp situation, they will not require watering until the tops begin to shoot. As soon as they commence to grow, light and moderate waterings are essential to the perfection of their flowers. Six-inch pots should be employed for this purpose. When done flowering, preserve in the same manner as described for spring and summerflowering bulbs. They may be planted from the first of November to the middle of December.

\section{BULBS IN GLASSES.}

The glasses should be filled with rain or river water to within about a quarter of an inch of the bottom of the bulb, as too much moisture, before the roots protrude, often causes the bulb to decay. The glasses should be placed in a light, but cool situation, until the roots have grown half the length of the glass, when they may be placed where wanted to bloom. The water should be changed twice a week; and, when the bulbs have finished making roots, they may be kept warm or cold, as the bloom is required in succession. All roots which have once bloomed in glasses, should be planted out as soon as the flowering is over, in order that they may recover. By this method, they can generally be bloomed every alternate year in glasses. When bulbs are backward in making leaves, they may be greatly assisted by filling the glasses with warm water. The bulbs should set steaty in the glass. Raw cotton will serve for this purpose. 


\section{CACTI.}

A mixture of loam, leaf-mould, and well-rotted manure, with sand duly ineorporited together, will serve for the successful culture of these beautiful flowering plints. The pots should, in every instance, have broken fragments of flower-pots placed in the bottom, to insure proper drainage; for without it, no success can be reasonably expected. When they are done flowering, thin out the least promising of the old and young wood, and place in a moderately warm situation until they start growing freely. Reduce the allowance of water gradually as they perfect their growth. When they have done growing, and the wood feels firm, the pots may be placed in some shady but airy place, protected from the drip of other plants or dampness, aud kept clean of moss. Plants managed in this mamner, will generally flower well. The Cacti may readily be propagated from cuttings and by grafting. To perform the latter operation, take a portion of a shoot, having at least four or five eyes, and shape the lower end into a wedge-like form. Cut off the end of a shoot, and make an incision in the top of the same sufficiently large to admit the graft. Insert the graft to the depth of a half inch, and secure with a small wooden peg. Large plants, having several different varieties grafted upon them, present a beautiful appearance when in flower. 


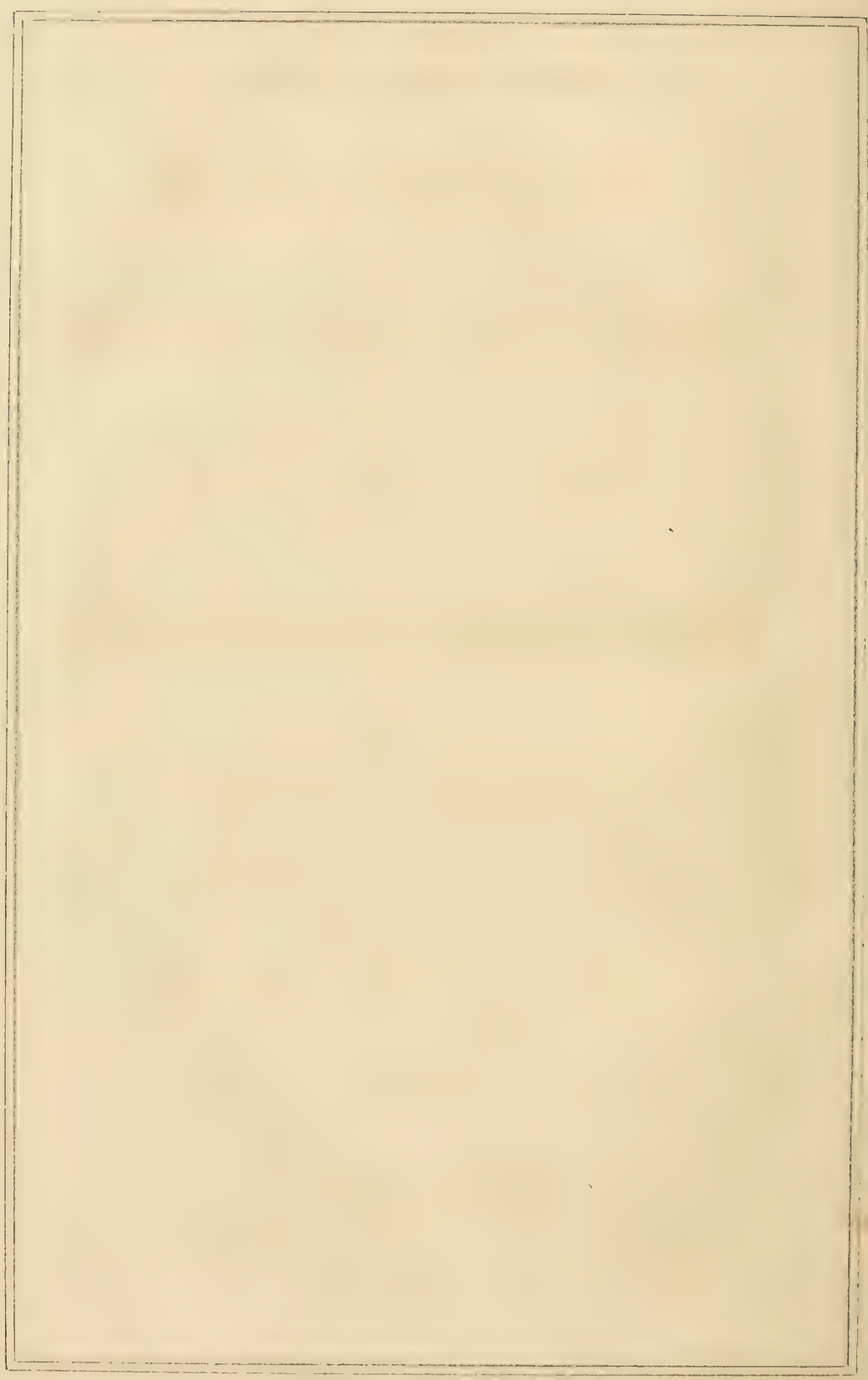




\title{
AMATEURS' GUIDE
}

\author{
AND
}

\section{VEGETABLE-GARDEN MANUAL;}

\author{
CONTAINING
}

PRACTICAL DIRECTIONS

FOR THS

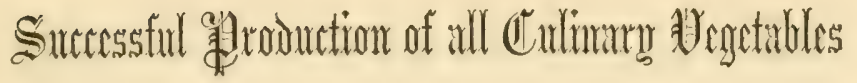

\author{
U S U A L L Y
}

CULTIVATED FOR TABLE USE.

CAREFULLT COMPILED FROM VARIOUS RELIABLE SOURCES BY JOHN T.C.CLARK.

WASHINGTON, D. C. PUBLISHED BY TAYLOR \& MAURY . 1856. 



\section{VEGETABLE-GARDEN.}

In the cultivation of the Garden, we experience a peculiar and innocent pleasure, which is increased in proportion to the knowledge acquired and the labor bestowed. Herein is food for the soul, the mind, and the heart, where all may obtain an abundant supply from the bounties of Nature, as developed at their own doors, and which, more than any other pursuit, afford rational and profitable pleasures, enabling us to find happiness in our own homes. "Cultivating the soil is like Charity-doubly blessed, in sowing and reaping." All systems of gardening should be conducted with discrimination. While proper attention is paid to the general directions, due allowance should be made for the difference of soil, situation, and climate, suited to each. Inattention to these important points, is the cause of want of success which proves so discouraging to the inexperienced Amateur. Much depends on the selection of good seed, for without them, all efforts will prove fruitless, and a barren waste will be the reward if this all-important object is not secured.

In order to place the means within the reach of all who are deterred from cultivating a garden by the want of practical knowledge, we have embraced in the following pages every requisite detail for the successful cultivation of the Vegetable-garden, carefully compiled from the "Encyclopedia of Gardening," "LanDretu's Rural Register," and other various reliable sources. In many cases their language has been employed, but it has not been thought necessary to mark the quotations. Should they be instrumental in enabling any to enjoy the exquisite pleasure of partaking of the vegetables raised by their own labor, the object of the compiler will be accomplished. 


\section{SITUATION OF THE GARDEN.}

A proper degree of shelter from cutting winds and full exposure to the sun should be secured. The ground should have a gentle declivity towards the south, inclining rather to the east, in order that it may receive the benefit of the morning sun. A northern exposure is unfavorable for general purposes, it being always cold and late. It must be admitted, however, that it is not without its advantages in summer, by retarding many kinds of regetables which would otherwise mature their seed before they had acquired a size sufficient for culinary purposes. Salads, spinach, and cauliflowers are brought to perfection in northern exposures, when they will make very slight progress if exposed to the full power of the sun. In such situations, peas and many other regetables yield more abundantly during the hot summer months, particularly in dry seasons. There should never be any trees of a considerable height on the south side of a garden, for, during the winter and early in the spring, they shade the garden when every sunbeam is valuable. On the east side also the trees should be removed, so as to admit the early morning rays of the sun.

\section{PROPERTIES OF SOIL.}

The soil best adapted for geueral garden purposes should be of a rich loamy texture, dry, mellow, and capable of being worked at all seasons, and from two to three feet deep. A loam of a middling texture, rather inclining to sand, will be found the most suitable for the majority of kitchen vegetables. If the soil be too strong, the roots of the plants push weakly into it, and are apt to canker and perish. If too light, and at the same time poor, the roots of vegetables will wander in search of food, and may be unable to collect a sufficient quantity for their support. Strong and stubborn clays should be avoided, being the most unfit of all 
others, as few vegetables will prosper in them. Gravelly soils are also unfit for garden purposes, being generally sterile and not readily enriched by manures, the finer particles being washed off by the rains. Jight sandy soils are not without their advantages, because they are much warmer, and by affording a still less quantity of moisture, the plants will not grow so luxuriantly, and therefore be much sooner fit for use than those grown on strong clayey soils. Early spring and winter vegetables are not only thus earlier on sandy soils than upon clayey, but are also much more capable of resisting the frost.

\section{PROPERTIES OF MANURES.}

The manures in general use are numerous. Horse manure is considered the best for general garden purposes. The manure of eattle, if slightly fermented, is well adapted for light, hot soils. It is also well calculated for soils of a dry, absorbent nature, as it retains its moisture for a greater length of time than most others. Green vegetable matter forms an excellent manure. Bird offal is a powerful manure, and should only be used as a compound, or if used as a simple manure, great care must be observed in its application. Soot is also a very strong manure, and should only be used in dry weather, and applied to the surface of the soil. Woodashes, if not too much burnt, is considered to be the most lasting manure, and, when used for turnips, is supposed to protect them against the ravages of the fly. Lime is an excellent manure, but should never be applied with animal manure, unless it be too rich, or for the purpose of preventing noxous effluvia. Manures, whether animal or mineral, are of such importance to regetation that all possible diligence should be used in the collection and preparation of them for the different purposes for which they may be required. By a proper application of them, founded on correct principles, the worst soil may not only be improved, but rendered fit for the production of erery regetable that is usually cultivated for the table. 


\section{KITCHEN VEGETABLES.}

The varieties in italic letters are the same, or essentially so, as those in Roman, which immediately precede them. The names of the SEASONS, and not those of the rontirs, have been used; consequently, seed directed to be planted early in the spring, should be sown as soon as winter has departed, whether that be on the 1st of February in the South, or in March with us. So, likewise, of the other seasons.

\section{ARTICHOKE.}

Cynara Scolymus,

French, or oval-headed.
Cynara Hortensis, Large Globe.

This vegetable is propagated from seed and offsets. If from the former, the seed should be sown in rows a foot apart, the middle of spring, and thinned to about the same distance as soon as they are an inch high. They should be kept clean from weeds, and the ground about them worked occasionally during the summer. When a year old, transplant to permanent beds, allowing each plant two or three feet square of room. They require a very rich soil. If propagated from offsets, the old plants should be examined for the most healthy, which must be separated with as much root as possible. Holes, about fifteen inches in diameter and twelve inches deep, must then be made about three feet from each other, and filled in with manure. Two or three of the offsets should be placed in each hole, six or eight inches apart, and lave a few inches of the tops trimmed off. Water them occasionally, and dig the ground well between them. Protect during winter by raising over them a mound of light dry earth.

The part principally used is the pulpy receptacle in the flowerheads, termed the bottom, freed from the bristles or seed-down. The tender central leaf-stalk, or mid rib of the leaf, blanched, is also used, and by some thought preferable to the cirrloon. 


\section{ASPARAGUS.}

Large Green Purple Top.

There are, it is said, several varieties of Asparagus, but the difference mainly arises from the nature of the soil. On strong loamy land, the growth is more robust and the shoots more tender than on sandy soil.

In making Asparagus beds, the chief point to be considered is to make choice of a proper soil. It should not be wet nor too strong, but moderately light and pliable, so that it will readily fall to pieces in digging or raking, and in a situation that receives the full sun. The ground intended for Asparagus beds should have a large supply of well-rotted manure, laid sereral inches thick, and should be then regularly trenched two or three feet, and the manure buried equally in each trench as the process goes on. The ground being leveled, it should be divided into beds, four feet and a half wide, with alleys two feet wide between the same. Four rows of Asparagus should be planted in each bed, ten or twelve inches distance being allowed between the plants in the rows, letting the outside rows of each bed be nine inches from the edge. They may be planted only in single rows, two feet and a half distant, or in uarrow beds containing two rows of roots only. It is of very great importance for insuring success in the planting of Asparagus to lift the roots carefully, and to expose them to the air as short a time as possible. While planting, it will be found advisable to keep the roots covered. No plant feels an injury in the root more keenly than Asparagus, and from the brittleness of the roots when they are once broken, they do not readily shoot again.

The sced of Asparagus should be planted early in the spring. Soak them in warm water for twenty-four hours, and drill them thinly in rows sufficiently wide apart to admit being worked with the hoe. When two years old, they may be transplanted to permanent beds, which should be so situated as to cast off an excess 
of moisture. They should be planted at least four inches beneath the surface, well manured at the time, and ammally thereafter. The sweetness and tendermess of the shoots depend very much on the rapidity of growth, and this is promoted by the richness of the soil. During the season of vegetation, they should be carefully weeded, and the alleys between the rows frequently hoed and kept loose.

\section{BEANS.}

ENGLISH.

1. Early Mazagan, Long Pod. English Horse Bean.

2. Sword Long Pod.

3. Broad Windsor. BUSH, OR SNAP SHORTS.

4. Early Six Weeks, Early Mohawk.

5. Red Speckled Valentine, Red Marrow.

6. Brown Speckled Valentine, Refugee, or thousand to one.

7. Red French.

8. Cranberry Busl.
9. Royal Dwarf, White Kidney.

10. Farly Tellow Six Weeks.

11. China Red Eye, Early China.

POLE, OR RUNNERS.

12. Large Lima,

Butter Bean.

13. Carolina Sewee, or Saba.

14. Searlet Runner.

15. Red Cranberry.

16. White Cranberry.

17. White Dutch.

18. Wren's Egg, or Horticultural.

This vegetable often fails, owing, in a great degree, to the heat of summer, causing the blossoms to drop. To obviate this, they should be planted as early in the season as possible, as soon as the frost is out of the ground. The first crop will be the best, the late sowu being apt to be destroyed by the heat. For five rows, each five yards long, one pint of seed will be enough in early sowings, and a quarter of a pint more for late sowings. Nos. 1, 2, and 3, are hardy, and may be planted quite early, indeed should be to secure crops, as they do not readily support heat. Nos. 4 to 11 , inclusive, are known as dwarf or bush Beans. The earliest is No. 4. Nos. 5, 6, and 11, are much esteened kinds. They may be planted for the first and successive crops from the middle of spring till the close of summer. The usual mode of culture is in rows, two or three in a clump, at intervals of ten to twelve inches. The runners require poles. Nos. 12 and 18 are tender, and 12 
particularly so, and should not be planted till the close of spring. They may be forwarled by sprouting them in a hot-bed, and transplanting them at the proper time. Yo. 18 is an excellent snap short, or may be shelled when more advanced.

When desired to be produced between the rows of cabbages or kile, it will be found to be more convenient to sow the seed in a warm border, and transplant them when about two inches high. They should be liberally watered at the time of planting, as well as on any subsequent occasion when they may require it. In selecting a spot to plant Beans, choose where the soil is light and tolerably dry. If it be poor, apply a good dressing of well-rotted manure, either spread over the entire surface, or plased in the drills when drawn out.

\section{BEETS.}

1. Extra Early Turnip-rooted.

2. Early Turnip-rooted Red.

3. Long Blood-red.
4. Swiss Chard.

5. Silesian, or Sugar.

6. Mangel Wurtzel.

The seed should be sown the middle of spring, in deep, rich, and well-manured gromd, in drills eighteen inches apart, and from eight to ten inches apart in the rows. Two or three seed should be put in each place, about half an inch deep. When the plants are two or three inches high, the weaker should be drawn out, leaving but one remaining in each space. Nos. 1, 2, and 3, are esteemed the best for table use. No. 1 is very early, light colored, and valuable as the earliest in the season. No. 2 is somewhat earlier than No. 3, equally good for winter use, and may be sown in drills from early in the spring till the commencement of summer. The leaves of No. 4 are used as Spinach, the mid-rib of the leaf as Asparagus, and is cultivated as the common Beet, but requires more room. Beets may be transplanted, and will attain to a very good size. To preserve for winter use, the roots should be taken up in autumn, the leaves cut off within a quarter of an inch of the crown, the roots exposed to the sun for a week or more, and then put away in some dry place, or packed in sand. 


\section{BORECOLE.}

\section{Dwarf German Greens, or Kale. 2. Scotch Kale.}

Under the head of Borecole is usually classed a large variety of the cabbage tribe, known as different kinds of Kale, but very distinct in appearance and modes of growth. No. 1 is an excellent green for winter and spring use. Being dwarf, it is casily preserved during severe weather. Sow early in autumn in good ground, either broadcast or in drills, and treat as described for Winter Spinach. Sow No. 2 in seed-bed middle of spring, and transplant and treat as directed for Winter Cabbage. This variety of Borecole is of upright growth, and not so well adapted for severe climates as No. 1.

\section{BROCOLI.}

1. Purple Cape.

2. Large Early White.
3. Sulphur.

4. Walcheren.

The Brocoli produce heads like Cauliflower, in autumn. No. 1 appears to be the best adapted to our climate. It is the only one to be relied on. Sow in seed-bed middle of spring, and transplant to very rich ground when eight to twelve inches high, and manage generally as usual with Winter Cabbage.

\section{BRUSSEL'S SPROUTS.}

This vegetable is cultivated for the small heads, which spring in considerable numbers from the main stem. Much esteemed in some parts of Europe, but here it has not received the attention it merits. The plant rises up with a very long stem, which las a spreading open head at the top, but which sends out from its sides great numbers of little cabbages, each being of the size of a large walnut. The large leaves should be broken off very early in autumn, in order to give the little cabbages room to grow. In 
Norember, these begin to he in perfection, and continue an excellent regetable throughout the winter. Much care is recquired in the saving of the sech of this plant. To effect which, the crown should be cut off, and the seed-stems and flowers allowed to come out nowhere but from the little cabhages themselves. It is most likely owing to negligence in this respect, that we scarcely ever see such a thing as real Brussel's Sprouts. Sow in seed-bed middle of spring, and transplant and manage as with Winter Cibloge.

\section{CABBAGE.}

1. Early York,

Early May.

Early Emperor.

Early Heart-shaped.

Early Royal Dwarf.

2. Landreth's Early York.

3. Landreth's Large York.

- 4. Early Sugar Loaf.
5. Early Battersea, Early Drumhead.

6. Green Curled Savoy.

7. Large Drumhead Savoy.

8. Red Dutch; (for pickling.)

9. Large Late Drumbead.

10. Flat Dutch.

11. Bergen.

12. Green Glazed.

Cabbages will thrive well in any richly-manured soil, provided it is not too dry. A stiff clayey soil is more suitable for them than a sandy or gravelly one, though the autumn and winter crops may probably suceed better when planted in a soil of the latter description, as those seasons of the year are generally wet. In summer, the plants will arrive at maturity sooner in such soils, though they be much smaller. The time for sowing the seed is very important, and should be regulated according to the time the crop is wanted. No. 1 is the earliest. Nos. 2,3 , and 4 , follow in quick succession. Those named as rarieties of No. 1 are so nearly alike, that it is difficult to point out the difference. Nos. 2 and 3 are valuable virieties, of larger growth than No. 1, not quite so early, but more robust, and support the heat better. No. 7 is a desirable variety for winter use, haring the tenderness of the Savoy, with the size and firmness of the Drumhead. Nos. 9, 10, and 11, are nearly alike, each producing large hard heads, and are cultivated for the winter supply. No dependance should be placed in imported Flat Dutch or Drumhead Cabbage seed, as they seldom produce a good 
head. The early and summer varieties are usually sown in seedbeds, early in autumn, protected therein, or in cold frames during winter, and transplanted early in the spring. Where the climate is mild, and the land light and dry, they are planted out in the :'utumn, in which ease they head earlier than those put out in the spring. Should a supply of plants not have been obtained in autumn, sow in hot-bed very early in spring, or somewhat later on a warm border in the open air. It should be borne in mind that, in no case, can fine Cabbage, and especially the earlier kinds, be had unless planted in heavily manured and well-tilled land. Heavy or strong loamy soils is best adapted to this crop, though deep tillage and strong manure will produce good heads on almost any soil The autumn and winter varieties should be sown in seed-beds from the middle to the end of spring, and transplanted early in summer. To have these kinds head early in the autumn, as a successinn crop, sow at the same time with the early sorts.

The Cabbage-FLY is frequently so voracious as to destroy the young plants the moment they appear above ground. A solution of tobacco frequently sprinkled over them, or air-slacked lime dusted on the leaves when damp, is sometimes effectual. Another method is to dust the plants when damp with a mixture composed of soot and ashes in equal parts. A solution of whale-oil soap, sprinkled over the plants, have resulted favorably. A weak solution of common brown or soft-soap would perbaps answer, where the former was not obtainable.

To preserve the heads during winter, bury the stalks and part of the head with earth, and, if the weather be very severe, sprinklo straw over the same. When the crop has been cut, if the ground be not immediately wanted, the stallis should be permitted to stand till a crop of sprouts be obtained. Where the ground is required for another crop, they may be takeu up with balls of earth to the roots and planted in a treuch in any spare cormer of the garden, at half a foot apart, always observing to deprive them of all their old leaves as soon as the head is eut off, that the young sprouts may receive additional nourishment. 


\section{CARDOON.}

\section{Large Solid Stalked.}

The tender stalks of the inner leaves, rendered white and delicate by earthing up, are used for stewing, and for soups and salad in autumn and winter. The seed should be sown early in the spring, and, when one year old, trinsplanted to permanent positions, allowing each plant a space of two or three feet square.

\section{CARROT.}

1. Long Orange.

2. Early Horn.
3. Altringham, or Field.

4. Large White, or Field.

In sowing Carrot seed, it will be proper to observe, that when the ground has a disposition to be wet, or is apt to bind, it will be found desirable to divide it into beds, four or five feet wide, with narrow alleys about one foot wide between the same. The seed should be raked in regularly, taking care not to draw the earth up in heaps. The seed have numerous forked hairs on their borders, by which they adhere, and should be well rubbed between the hauds, and mixed with dry sand, in order to separate them as much as possible previously to sowing. Being very light, a quict, still day should be chosen for sowing. For forty feet of drill, a quirter of an ounce is enough, and the same for a bed three feet wille and eleven feet long. Nos. 1 and 2 are esteemed the better linds for table use. The Early Horn is an admirable variety, and equally good for summer and winter use. Nos. 3 and $t$ are grown for stock. Though No. 1 is probably as good for that purpose, it does not grow quite so large as No. 4 , but is more nutritious. For domestic use, sow early in spring in drills, in deeply dug and well-manured ground. The drills should be twelve or eighteen inches apart. When the plants are up a few inches high, weed and thin them so as to stand at least six inches from each other, exeept those intended for early use, which may be thinned by 
drawing the daily supply. To preserve for winter use, remove to a cellar, or protect them where they stand.

\section{CAULIFLOWER.}

\section{Early Asiatic.}

2. Late Dutch.

The seed of the early varieties should be sown in seed-beds the beginning of autumn, kept in a cold frame, protected from severe frost during winter, and transplanted to very rich ground as soon as frost ceases. When first put out, hand-glasses, or inverted flower-pots, should be placed over the plants at night. The late variety matures in autumn, and should be sown at the same time, and managed the same as Cape Brocoli, which see. It is not, however, so certain to succeed as the Brocoli, which it resembles in quality, nor is a better vegetable when obtained.

\section{CEI LRY.}

1. White Solid.

2. Red Solid.

3. Celeriac, or Turnip-rooted.

Early in the spring, prepare a small bed of light rich earth, in a warm aud moist situation, and convenient to water, in which sow the seed for an early crop. Break the mould very fine, as the seed is small, and rake the surface even. Sow the seed, but not too thickly, and cover with light rich mould, about a quarter of an inch deep. Give water freely in dry weather as the plants make progress. The plants should be kept thin in the seed-bed, and pricked out when fit upon the surface of fresh earth, well manured. They should be watered and shaded until they take root; and, in dratwing from the seed-bed, let some of the strongest plants remain, to be put out for an early drill. They should be planted out before they become too strong. If they have acquired a large ball of earth and roots, these and the straggling leaves on the sides should be cut atway, in part, before planting out to remain. The transplanting should be repeated at intervals of two or three 
weeks, for a succession, until the necessary quantity be set out. It is not prudent to surcharge the beds with manure, which sometimes burns the plants. A safer plan is to put a part on the surface, around the plants, which, in the course of tillage, becomes incorporated with the soil. For the autumnal crop, the white is superior in flavor, but the red is better calculated for standing through the winter. If long and hard frost be apprehended, a sufficient quantity for domestic use should be taken up and placed in a bed of sand or light earth, in a shed or cellar. When the ground is deeply frozen, it is sometimes impossible to get it out without tearing it to pieces. It may be kept very well for several wecks in a cellar. To save the seed of Celery, take one or two plants in the spring out of the ridge that stands last and replant it in an open place, and they will furnish seed sufficient for several years.

Particular attention should be paid to earthing up Celery. The soil should be dry, or it is apt to rot the plants and render them unfit for use. As the plants advance in growth, blanch by earthing up gradually. That intended for late winter and spring use, had better not be blanched preparatory to being laid up.

\section{CHERVIL.}

This vegetable is used in soups and salads, and cultivated after the manner of Parsley. When wanted for summer use, sow in narrow drills early in the spring, and late in summer for the autumn and winter supply.

\section{CORN SALAD, OR LAMB'S LETTUCE.}

Used as a small salad throughout the winter and spring. Sow thickly in drills first of autumn, and sprinkle with straw on the approach of severe weather. 


\section{CRESS.}

Curled, or Pepper-grass.

Broad-leaved Garden.

Used as a small salad. Sow very thickly in shallow drills on a smooth surface, at short intervals throughout the season, and eut before it comes into rough leaf.

\section{CRESS, WATER.}

A running stream of clear water is essential to the cultivation of this popular salad. The plants should be inserted in rows, in the bed of a stream, and in the direction of the current. The bed should be taken up and replanted occasionally, and the plants kept free from mud and other extraneous matters. When the plants begin to grow in water one inch and a half deep, they soon check the current so as to raise the water to the height of three inches above the plants, which is considered the most favorable circumstance in which they can be placed. After they have been cut about three times, they begin to stock, and then the oftener they are cut the better. No other plants, and especially the Srum NODIFLORUM, a poisonous plant resembling the Water Cress, should be permitted to find their way into the bed. The beds should he laid dry two or three times a year, to permit weeds and decayed parts to be removed, and vacancies to be filled.

\section{CUCUMBER.}

\section{Early Frame, or Table, Short Prickly. \\ 2. Long Green, or Turkey. \\ 3. Gherkin, (for pickling.)}

For early use, plant in hills, on a warm border, the latter end of spring, and for a succession erop, on an open compartment. For pickles, plant middle of summer, and manage as usual with the early kind. No. 1 is a short prickly variety, quite early, and productive. No. 2 is the best of the long varieties, principally 
used for pickling, though many prefer it for slicing. No. 3 is used altogether for pickles, and cultivated in the ordinary manner. Previous to planting, a shovel full of well-rotted manure should be placed in each hill; after which, four or five seed may be sown half an inch deep. One ounce of seed is sufficient for two hundred hills. When attacked by the fly, if soot, powdered charcoal, or tobacco dust, be sprinkled over the plants, it will generally serve to eheck their ravages. When the plants have made a growth of two or three inches, they should be thinned to two or three in a hill, the ground carefully hoed, and the earth drawn up around them. The ground should be kept free from weeds, and in very dry weather, the plants watered occasionally in the evening.

\section{CHIVES, OR CIVES.}

A small species of Onion, growing in large tufts. Propagated by offsets, and planted in either spring or autumn, in rows ten or twelve inches apart, and the bulbs three or four inches apart in the rows.

\section{EGG-PLANT.}

1. Large Purple.

2. Early Purple.

The seed of the Egg-plant must be sown in a hot-bed, early in the spring, and the sashes kept down close until the plants come up; after which, a little air should be given in the heat of the day. The latter end of spring, if settled warm weather, the plants may be set out, about two feet apart, in a rich, warm piece of ground. If kept clean, and a little earth be drawn up to their stems when about a foot high, they will produce plenty of fruit. The seed do not regetate freely, and repeated sowing are sometimes neeessary. As Egg-plants will not grow in the open ground until settled warm weather, and are frequently destroyed by frost when planted too early, it will be found advisable to transplant them 
into small pots, and placed in a frame until frost has ceased, when they may be turued out and planted, with the balls of earth unbroken. In which ease, they will soun take root and grow frecly.

\section{ENDIVE.}

1. Curled,

Green and White curled.
2. Broad-leaved, Batavian, or Scarolle

The proper season for the sowing of Endive is the latter end of spring. If sown much earlier, it generally runs off to seed. Sorv the seed about half an inch deep, in drills eighteen inches apart, and press the earth down clusely upon the same. When the plants are up, they should be thimned to eighteen inches apart in the rows, so that they will stand throughout the bed at eighteen inches from each other. The plants which are drawn, if wanted, should be trausplanted into good ground, the same distance apart, and immediately watered. When the plunts have attained a modcrate size, they must undergo the process of blanching, which is performed as follows: Gather the whole plant up in your hands in a conical form, and tie it round with matting, which should go several times round the plant, causing it to end so pointedly at the top as to prevent the rain or dew from penetrating to the interior. Particular care should be observerl, in blanching the plants, that the leaves are perfectly dry; otherwise, corruption is apt to ensue, and the plants entirely spoiled. The great difficulty with Endive is to have it for winter use; for, though it is hardy, it will rot if kept tied up too long.

\section{HORSE-RADISH.}

To have this plant fine and in profusion, all that is necessary is to select, carly in the spring, straight young roots, two or three inches long, and plant them one foot apart each way, in rich, moderately dry, loose soil, keeping the ground hoed and free from weeds. On the arrival of cold weather, remove such as may be 
required for winter use to some sheltered place, or cover them with litter as they staud, that they may not be frozen in.

\section{INDIAN CORN.}

1. Sweet, or Sugar.

2. Early Canada.

3. Early York, Adam's Early.
4. White Flint, (early and late.)

5. Cooper's Prolific.

6. Tuscarora.

7. White Flour.

The early varieties of Corn intended for boiling when young, should be planted the middle of spring, in hills four feet apart, or in drills. A shovel full of well-rotted manure should be placed in each hill, before the seed are planted, and after the plants are up strong, scatter a handful of wood-ashes around each hill. The ground should be dug deeply between the rows when the plants are about eighteen inches high. No. 1 is the best table Corn. Nos. '2 and 3 are the earliest. No. 5 is a productive kind for furm culture. To grow No. 1 of large size, and in full perfection, the ground should be in good condition and recently manured. For a succession crop, plant the latter end of spring.

\section{JERUSALEN ARTICHOKE.}

This plant may be readily propagated by cutting the roots into sets, with two eyes each, and planting them, early in spring, in the same manner as Potatoes. To have them in perfection, they should be hoed frequently, and the ground kept loose around them. Care should be taken to gather them out clean when digging for use, as the sirallest particle left will grow and encumber the ground, without producing a crop worth standing.

\section{LEEK.}

Large London, -Scotch, or Flag.

The seed should be sown as early in the spring as the weather and the ground will permit, in drills of fine earth, about an inch 
deep, and of a sufficient distance apart to admit of a small hoe. Keep the ground clean and loose around the plants, and transplint the middle of summer, in good ground, in rows twelve inches apart, and the plants five or six inches distant from each other. After the plants have taken root, they should be frequently hoed and kept free from weeds. When desired to have Icek's blanched, they should be planted in drills, three or four inches deep. As the plants grow, draw up to their sides the earth which came' out of the drills. This should be repeated at intervals until each plant has attained a sufficient size for use. Ieeks will stand the winter without protection, but, as a provision agrainst hard frost, some should be taken up and packed in earth or sand, in some dry place, for winter use. Two or three plants which have stood the winter should be left to produce seed, which will ripen early in autumn. One ounce of seed will be sufficient for a bed four feet wide and twelve feet long.

\section{LETTUCE.}

1. Early Curled, or Cut Salad.

2. Early Cabbage, Butter Lettuce.

3. Brown Dutch.

4. Royal Cabbage,

Drumhead.-Imperial.

Grand Admiral.
5. Philadelphia Cabbage.

6. Curled India, or Ice.

7. White Cos.

8. Green Cos.

9. Palestine.

The kinds enumerated are perhaps more numerous than need be cultivated, and the same variety has frequently so many local names, it is difficult to designate them. No. 1 is used as a small silied, and should be sown very thickly, on a smooth surface, early in the spring. Nos. 2 and 3 are good sorts, of about equal merit. Nos. 4 and 5 succeed Nos. 2 and 3, and produce large firm heads. No. 6 is a valuable variety, and stands the heat well. Nos. 7 and 8 are very crisp and tender, but soon shoot to seed. To have fine hear Lettuce, the seed should be sown, in seed-bed, from the first to the middle of autumn. Protect the plants by a cold frame, or with litter, as they stand in the ground, and transplant early in 
the spring into rich ground. For a large supply, sow in drills, from time to time, during spring and summer, and when up a few inches high, thin out the plants to twelve inches distance from each other every way. For this purpose Nos. 4, 5, and 6 are the best varieties. Lettuce may be blanched as directed for Endive. One-eighth of an ounce of seed will be sufficient for a bed three feet wide and seven feet long, and will produce between two and three hundred plants.

\section{MELON, OR CANTELEUP.}
1. Green Citron.
6. Large Musk.
2. Pine Apple.
7. Christiana.
3. Nutmeg.
8. Hunter,
4. Skillman's Fine Netted.
5. Large Yellow Canteleup. Hooseinee Canteleup. 9. Turk's Cap Citron.

Melons should be planted the latter end of spring, in well-manured and deep-dug ground. Mark it out into squares of six feet every way, and at the angle of every square dig a hole twelve inches deep and eighteen inches in diameter, into which place old rotted manure to the depth of six inches, and four inches of soil over the same, and incorporate both well together with the spade. Draw the soil over the mixture so as to form a circular hill about a foot broad at top, and sow in each hill six or eight seed, about two inches apart from each other, and cover about half an inch deep. When the plants commence producing their rough leaves, they should be thinned to two or three in a hill, and have the earth drawn up, from time to time, as high about the roots of the plauts as the seed-leaves. As soon as the plants spread into branches, the top of the first runner-bud should be pinched off, which will greatly strengthen the plants and enable them to perfect their fruit early. The ground should be kept free from weeds by frequent hoeings. No. 1 is roughly netted, flesh melting, very sweet, and high flavored. No. 2 is of medium size, rough netted, and flesh thick, firm, juicy, and sweet. No. 3 is somewhat larger and more globular, flesh green, and very highly scented. No. 4 * 
is a small, rough-netted variety, with green flesh, very thick, firm, sugary, and of the most delicious fragrance, and the earliest of the green-fleshed varieties. No. 5 is slightly ribbed, netted, good sized, and musk-flavored. Flesh salmon-colored, and earlier than the green varieties. No. 6 is deeply ribbed, musk flavored, early and productive. Flesh thick, and light salmon-colored. A large variety, and used when green for mangoes. No. 7 is some ten days earlier than No. 3, but not equal in flavor, though an excellent variety. No. 8 is an esteemed variety, very large, and of fine flavor. No. 9 is a variety of No. 3 , and is perhaps the best of its class. In order to have Melons in good perfection, the different varieties should be planted remote from each other, and also from Cucumbers, Gourds, Pumplins, and Squashes, or degenerency will be the consequence. In saving the seed of the Melon, the fruit should be cut crosswise, and the seed taken from the vine end. If taken when the fruit is just ripe, they will be found to be less impregnated than those saved by the ordinary method.

\section{WATER-MELON.}

\section{Mountain Sprout,}

2. Spanish.
3. Long Island.

4. Citron, (for preserves.)

5. New Orange.

To have Water-melons in good perfection, they should be sown in very rich, light soil. Prepare, plant, and manage in every respect as directed for the others, only let the hills be seven or eight feet distant each way. One ounce of sced will plaut from forty to fifty hills. No. 1 is a large, long striped variety, with bright scarlet flesh and drab-colored seed. A fine and desirable variety. No. 2 has scarlet flesh and black seed. It is smaller than some of the other varieties, but has a very thin rind and a rich sugary flavor. No. 3 has red flesh and grey seed, and is earlier than either of the above. No. 4 has white and solid flesh and red seed, uniformly round and smooth, striped and marbled with light green, and cultivated for preserving. No. 5 has red 
flesh, of medium quality, and short thick seed. The rind may be taken off like that of an orange.

\section{MUSHROOM.}

About the end of summer, take some stable manure that is not fresh and fiery, and throw it up into a compact heap to ferment. Early in autumn, when the manure is sufficiently fermented, aud has lost all the disagreeable efluvia, mark out a bed three or four feet wide, in any dry, warm situation. The length must be regulated according to the quantity intended to grow. A shed with a southern aspect would be a very eligible place for a bed. The manure must be well shaken up; and, if long, should be beaten well, and drawn in, by degrees, until it assumes the shape of the roof of a house. It must not only be beaten at the top, as it is gradually carried up, but should be beaten at the sides; for it is there that the bed should be perfectly even and firm. Having, in this manner, finished the bed, it must be protected, not only from the rains, but from the sun, by covering it over with long straw, thatch, or moss, for it must be neither too wet nor too dry. It should remain in this state for about a week, or until the fermentation has moderated to about blood heat. Then put on a layer of strong, rich, fresh mould, about two inches thick, in which holes must be inade about eight inches apart every way. Into each of these holes place some little pieces of the spawn of mushrooms, which must be covered over with a layer of mould about an inch in thickness, and beaten down smoothly with a spade. The covering of straw, or matting, must still be kept over the bed, for it must not be exposed immoderately to either the sun or the rain. Success now greatly depends on the proper moisture of the bed. In summer, the covering should occasionally be taken off, to admit of gentle showers falling upon it. In very dry seasons, it should be gently watered with lukewarm water. The spawn must be dry, with a pleasant odor, like a fresh Mushroom; not advanced into white threads, similar to the spawn which is collected in the 
fields, but having a small spotted whitish appearance. In about a month, the young mushrooms will begin to appear, when, if the clay appears dry, and the weather mild, a liberal supply of tepid water should be giren. In fine weather, the covering should be taken off for a few hours, which has a tendency to keep the bed in a healthy state. Should the weather be cold, a few minutes will be sufficient. The covering must, in all cases, be regulated according to the temperature of the atmosphere.

To make Mushroom spawn: To any portion of fresh horse manure, mixed with short litter, add one-third of cow manure, with a small quantity of mould to cement it. Mash the whole into a thin compost, and spread it on the floor of an open shed until it becomes firm enough to make flat square bricks. Which being done, set them on edge and frequently turn until half dry, when make two small holes in each brick, and insert a piece of good old spawn the size of a walnut in each hole. The bricks should then remain until they are dry. This being completed, level the surface of a picee of ground, (if the floor of a shed or house be not convenient,) three feet wide and of length sufficient to receive the bricks, on which lay a bottom of dry horse manure six inches thick. Place the bricks in rows, one upon another, the spawned side being uppermost. Cover with a sufficient quantity of warm horse manure to effuse a gentle heat through the whole. When the spawn has spread itself throughout every portion of the bricks, the process is ended, when they should be laid up in a dry place for use. Spawn made in this manner, if well dried before spring, will preserve its properties for many years.

\section{MUSTARD.}

White.

Black.

The seed of each rariety should be sown the middle of spring, in shallow drills of clean rich ground, and covered with a light, thin layer of fine mould. For a fall salad, sow the begiming 
of autumn. Due precaution should be taken to protect the seed from the ravages of birds. The white variety is much esteemed as a medicine, and from the seed of the brown variety is manufactured the condiment in daily use.

\section{NASTURTIUM, OR INDIAN CRESS.}

The flowers and young leaves of this plant are used as salad. The seed-pods are gathered when green and tender and pickled as a substitute for capers. The seed should be sown from the middle to the end of spring, in drills about an inch deep. If support be given them on which they can climb, they will prove more productive than when suffered to trail on the ground.

\section{ONION.}

1. Silver Skinned, or White.

2. Large Yellow Strasburg.

3. Large Red Wethersfield.

In order to insure a good crop of Onions, the ground should be well prepared by digging in a plentiful supply of old and strong manure, very early in the spring. The sooner this be done the better. Sow the seed the middle of spring, moderately thick in drills one inch deep, and twelve inches apart. When the plants are up three inches high, thin them to three inches, and afterwards, for the daily supply, to eight inches apart. The beds should be carefully weeded, care being taken not to disturb the earth much or raise it round the plants, which will prevent them forming their bulbs properly. When the leaves begin to loose their color, lay down the crop by bending the stems down flat, just above the bulb. This process will check the growth of the stem, and afford nourishment to the bulb. Onions should be taken up the first of autumn, spread thinly on the ground, and turned over once or twice a day until thoroughly dried, and then stored away in any dry, airy situation. If spread thickly, they must still be turned occasionally, or they may be strung or hung up in nets. 
Seed Onions are generally planted in the spring, in shallow drills, fourteen inches apart, but will survive the winter, and yield better by being planted in autumn, if slightly covered with litter, long manure, or leaves. Onions are an exception to the general rule of never cropping the same ground successively with the same crop, as they succeed any number of years if the ground be kept highly manured. Nos. 1 and 2 are esteemed varieties. The latter keep best, though not so delicately flavored as the former. No. :3 is grown extensively in the eastern States, where it matures the first season.

OKRA.

This vegetable is used extensively in soups and stews. It is highly nutritious, and deemed very wholesome. Sow the seed late in spring, in hills two or three feet apart, and two or three seed in each, - or in drills, three feet apart, and eight or ten inches between the same. The seed are liable to rot in the ground, and should be sown thickly to secure the requisite quantity of plants. Very rich ground should be selected for its culture.

\section{PARSLEY.}

Curled, or Double.

Plain, or Single.

Soak the seed a few hours in warm water, and sow very early in the spring, in drills an inch deep, and one foot apart. If corercd with straw or the branches of erergreens, it may be preserved through the winter.

\section{PARSNIP.}

Sugar,-Hollow Crowned, or Capped.Lisbonaise.

Sow the seed from the first to the midule of spring, in deeplydug and well-manured ground, in drills, one inch deep aud four- 
teen inches apart. When the plants are up two or three inches high, thin them to stand six or eight inches apart in the rows. A quarter of an ounce of seer is sufficient for a bed four feet wirle and twelve fect long. The beds should be kept free from weerls. aurl frequently hoed through the summer. In autumn they will he fit for use. The Parsnip will stacd the frost without injury. and are benested thereby; for, after being frozen, their flavor is greatly improved.

PEAS.

1. Landreth's Extra Early.

2. Early Frame, Early Washington. Early May.

3. Early Charlton, Golden Hotspur.

4. Bishop's Dwarf Prolific.

5. Dwarf Blue Imperial.

6. Royal Dwarf Marrowfat.
7. Large White Marrowfat

8. Peruvian Black-ere Marrowfat.

9. Knight's Dwarf Marrowfat.

10. Knight's Tall Marrowfat.

11. Matchless Marrowfat.

12. Blue Prussian.

13. Dwarf Sugar, or Eat-pod

14. Tall Sugar, or Eat-pod.

Peas should be somn as early in the spring as the ground will permit, in a warm dry situation, and eovered about three inches deep. They are the most productive in a light, but rich suil, but may be grown, with care, upon almost any soil if it he well matnured and drained if inclined to be wet. Peas should be sown in double rows, nine iuches from each other, as much ground will be siaved by this method, and they only require half the number of stakes as they would when sown in single rows. The seed should be somn mollerately thick, to allow for the depredations of insects or vermin, and having been covered, tread the surface of the soil lightly. As soon as the tendrils appear, stakes should be placed along the rows, from four to seven feet high, according to the gromth of the different varieties. No. 2 is an execllent variety, but some ten days later than No. 1. No. 3 is a productive rariety and succents No. 2. No. 5 is a luscious varicty, and generally much estecmed. Nos. $6,7,8$, and 12 are very productive, and when sown at the same time with the early varieties, form an 
uninterrupted succession. The first plantings should be made as soon as the ground can be worked, and for a regular succession, sow at short intervals during the spring and early part of summer.

\section{PEPPER.}

1. Large Sweet, Bell-shaped.

2. Tomato, or Flat.

3. Cayenne, or Long.

Sow late in spring or first of summer, in drills, on a warm border, and when up three iuches high, thin them to stand eighteen inches apart. They may be be sown early in the spring, in a hotbed, and transplanted as soon as frost has ceased. Nos. 1 and 2 are principally used for pickling when green. The first is quite mild and attains a large size. No. 3 is usually ground, when ripe and dried, for table use, though the green pods are also pickled. One ounce of seed will produce about three thousand plants.

\section{POTATO.}

1. Fox's Seedling.

2. Walnut-leaved.

3. Foxite.

4. Mercer.

The best soil for Potatoes is a rich, sandy loam, for they will not prosper on stiff, heavy, clayey, or wet soils. From the middle to the end of spring is the time for planting the general crop; but if planted the beginning of spring, a very good crop may be obtained, without being liable to injury from frost, which frequently occurs with those that are planted earlier. In planting cut Potatoes, take care to have two good eyes in each set. The small Potatoes should be deprived of the sprout or nose end, as a redundancy of eyes exhaust the set and produce weak plants. The sets should not be planted until a week after being eut, in order to afford them time to dry. Plant in drills, four or five inches deep, and about thirty inches apart. The sets may be dropped six or eight inches apart. When uncut Potatoes are used for seed, all the eyes but one ought to be scooped out, and should be planted 
at groater distances, in order to give room for the plants to get light and air. The eyes or buds nearest the root fibre sprout a week or more later than those furthest from it. In planting out sets, therefore, the two sorts of eyes should be planted in separate rows. Potatoes for planting are always found to answer best when proeured from a different soil, as they seem to like a change of food. The ground should be hoed as soon as the plants come up, and as they progress in growth, the space between the ruots ought to be well dug, to loosen the soil and encourage the spreading of the roots. When six inches high, the soil should be drawn up to the stem, so as to cover the Potatoes at the surface from the light, which turns them green and acrid, and to permit the air to penetrate to the roots the farthest spread. Another hoeing will be afterwards necessary, to keep the vines from falling down. The withering of the plants point out the proper time for digging up the crop. If any be dug before those symptoms appear, they ought not to be exposed to the sun, which will render them acrid and injure their flavor. Potatoes intended to be eaten, cannot, probably, be too ripe. Such, however, as are intended for seed, should not be allowed to become too ripe, as, in that case, they are more subject to the disease called the curl, and which is often very detrimental to the crop.

\section{POTATO, SWEET.}

Yellow.

Red.

Sweet Potatoes should be planted whole, the middle of spring, in a hot-bed, three or four inches deep, and about the same distance apart. In about a month they will throw up sprouts. When these are three inches above ground, separate them from the Potato, which, if suffered to remain, will produce more sprouts for a successive planting. Transplant them into rich light soil, in rows four feet distant, and the plants about a foot apart in the rows, or in hills four feet apart. Keep them clear of weeds until the vines begin to cover the ground, after which they will grow 
freely. In sandy ground, it will be found advisable to put a shovel full of well-rotted manure to each plant. A moderate hotbed, five feet square, put down the middle of spring, with half a peck of good sound Sweet Potatoes planted therein, will produce a succession of sprouts which, if planted and managed as directed, will yield about fifteen bushels of Sweet Potatoes.

\section{PUMPKIN}

1. Cashaw.

2. Common Field, or Cheese.

3. Mammoth.

Pumplin seed should be sown the latter end of spring, in lills, eight or ten feet apart, with two or three seed in a hill. They are not so tenacious of a particular soil as either Melons or Cucumbers, but in other respects are cultivated in the same manner.

\section{RADISH.}

1. Long Scarlet Short-top.

2. Long Salmon.

3. White Turnip-rooted.

4. Red Turnip-rooted, Cherry.

5. Yellow Turnip-rooted, Yellow Summer.
6. Summer White.

7. White Spanish, Fall, or Winter Black.

8. Black Spanish, Fall, or Winter White.

The two first named are not very dissimilar. No. 1 is generally preferred for its brilliancy of color, though No. 2 is the most brittle, and of course the best. Nos. 3 and 4 are excellent varieties and enrly. The first four named are generally used for the earlier sowings, which should be made on a sheltered border, as soon in the spring as the ground can be worked. The soil should be well manured, decply dug, and raked free from clods and stones. Sow the seed broadeast and rake in evenly, or in drills, about one inch deep, and a foot apart. If cold weather return after the seed have sprouted, protect by branches of erergreens, straw, de., which should be remored so soon as it may be prudent. Nos. 5 and 6 are better adapted to the summer than the 
jreceding, which, in warm dry weather, soon beeme tungh and sticky. For an uninterrupted succession, sow these varieties at the sime time with the earlier kinds. Nos. 7 and 8 are grown for winter use, and should be sown at elose of summer or early in autumn, and when ripe, stored away in some dry place, free from frost. For a bed three fect wide and nime feet long. one ounce of seed will be sufficient for spring varieties, aut thee-cuurters of an ounce for autumn and winter varieties.

\section{ROCAMBOLE.}

The bulbs of the Rocambole is of a milder and better flavor, but not so large, as the common Garlic. The seed should be sown in drills, shortly after they are ripe, or in the ensuing spring. They must be kept clean of weeds; and, in autumn, may be taken up, the offsets sepurated, and again planted, in rows twelve inches apart, and six inches distant in the rows.

\section{RHUBARB, OR PIE-PLANT.}

The Rhubarb, of which there are several varieties, is cultivated for the foot-stalk of the leaf, which possesses an agreeable acidity, and resembles the gooseberry when made into pies or tarts. It is fit for use before green fruit can be had, and is an excellent substitute. The seed should be sown early in spring, or late in autumn, in a border with a mortheru exposure, and scatterd thinly in drills, two inches deep, and one foot apart, and slightly covered mith soil. When the plants appear, they should be thinned out to about six inches from each other, and afterwards to a foot. The plants thinned out may be planted in a similar situation, if required. In this ealse, they must be taken up with care, so as not to lreak the roots. As soon as the leares are decayed, the seedling plants should be taken up carefully and plauted out in rows two feet apart, and the same distance between the plants. When 
planted further apart, a great portion of ground will be wasted, as they are not injured by being shaded by each other. Rhubarb should be planted in a shady or northern situation, as their stems will be finer and better when not too much exposed to the sun. Any rich soil will grow Rhubarb, which will require an annual top dressing of well-rotted manure. This should be applied in the autumn; for, during the winter, the nutriment which it contains will be conveyed down to the roots by the rain, and it will also cause the leaves to commence growing much earlier in the spring. As seedling plants do not produce stems fit for use till two years after the time of sowing, if plants are desired to be obtained sooner than they can thus be brought into use, the old plants may be taken up and separated into as many parts as there are crowns or eyes, leaving a portion of the root to each. These may be planted out when desired, and they will soon produce stems sufficiently strong for any required purpose. On the approach of severe weather, seedling plants should be covered with straw or the branches of evergreens, which must be removed early in spring, and the ground well hoed and eleared of weeds.

\section{SALSIFY, OR OYSTER-PLANT.}

The roots of this plant are boiled like Carrots, as a regetable dish, or, after being parboiled, made into cakes, with paste, and fried like oysters, which they closely resemble in both taste and flavor. The stalks of one year old are sometimes used in the spring as Asparigus. The seed may be sown, from the first to the middle of spring, in deep, rich loamy soil, moderately thick, in drills, an inch deep and twelre inches apart When the plants are two or three inches high, they should be thimnet to the distance of six inches from each other, and afterwards loed. The ground should be kept clean and loose around the plants, by hoe- ing, and in the autumn they will he fit for use. The roots mity be taken up late in autumn and secured in sand, or suffered to remain out, and dug up when wanted. 


\section{SCORZONERA, OR BLACK SALSIFY.}

The roots of this vegetable are very palatable and nourishing, and is principally used as an ingredient in soup. Some prefer it to the common Oyster-plant. It is sometimes eaten like Carrots. In which case, they should be deprived of their rind and immersed in cold water for half an hour, or they will be bitter. They are cultivated in the same manner as the preceding.

\section{SCURVY GRASS.}

Used as a small salad throughout the winter and spring. Sow broadeast, or in shallow drills, early in autumn. Protect through the winter by covering lightly with straw or the branches of evergreens.

\section{SEA-KALE.}

The soil most suitable to this plant is that which has a considerable proportion of sand in its formation. In preparing the ground for the seed, which should be sown as early in the spring as the ground can be prepared, or the middle of autumn, dig it deeply, and sow in drills an inch and a half deep, and sixteen inches apart. The plants should be thinned out to the distance of six or eight inches from each other in the rows, and kept clear of weeds by frequent hoeings. When the plants are a year old, every third row may be taken up, and also every other plant in each row, learing them eighteen inches apart, which may be transplanted into good ground prepared as directed for Asparagus. Plant two rows in each bed, about eightecn inches apart. The better mote is to make two drills three inches deep, and insert the plants about sixteen inches apart. When these drills are filled, the crowns of the plants will be covered nearly two inches, 
but they will soon push through the earth. New beds may be formed with pieces of old roots, which should be cut into lengths of about two inches, and planted the beginning of spring, three or four inches leep, and sixteen inches apart. In autumn, spread long stable-minure over the beels as a protection from extreme frost. Is soon as the frost is out of the ground, this may be taken off, or if well rotted, dig some in around the plants. Early in the spring, the crowns of the plints should be covered to the depth of ten or twelve inches for lianching. This may be done by placing over them a liyer of dry sand or gravel, an inch thick, aud over each cluster of plant: a blanching-pot, box, or anything to exclude the light, pressing it fimly in the ground, an admission of air being injurious to both color and flavor. If the pots or boxes used for this purpose be covered with fresh horse manure, it will forward the shoots in growth, and make them sweeter and more tender. When the plants have been covered three or four weeks, they should be examined, and if the stalks have made a growth of three or four inches, they may be cut. Care should be taken not to injure the crowns by cutting the shoots too close. If the beds are ammully dug and manured, they will last many years, and will prove very productive.

\section{SHALLOT, OR ESCHALLOT.}

This vegetable has a strong, but not unpleasant odor, and is prefereal by many to Onions for seasoning various dishes. It is propagater by offsets, which should be planted out in autumn, in rows twelve inches apart and six inches distant from each other. If planted the latter end of summer, they will be fit for use the midllle of spring. The bulbs should be taken up when full srown, when the leaves begin to decay, and spread out to dry, in some airy situation. 


\section{SKIRRET.}

The seed shoukl he sowu very early in the spring, in trills a puarter of an inch deep, and twelve inches apart. It is also progagated by oinets, taken from the old roots, and planterd very carly in the spring, before they begin to shoot. When the leaves hegin to lecay, in autmmn, the roots are fit for use, and continue so until they commence sprouting in the spring.

\section{SORREL.}

Used as salad. Sow the seed the middle of spring, in shallow drills, and thin the plants to twelve inches apart.

\section{SPINACH, OR SPINAGE.}

1. Round Saroy-leared.

2. Prickly Seed.

Spinach requires a richer soil than almost any other culinary vegetable to bring it to perfection, as it has to yield frequent cuttings, and therefore requires a frequent derelopement of parts, which cannot be expected without an abundance of food. The seed may be sown broadcast, or in drills one foot apart. For spring and early summer use, sow as carly as the ground can be worked. For the autumn supply, sow the close of summer. For winter and early spring use, sow the middle of autumn. The latter sowing will need protection on the arrival of cold weather, and should have a light covering of straw, or long manure, during winter. When the autumual somings are made during hot, dry weather, the seed is difficult to vegetate. No. 2 is the most hardy and well adapted for autumm sowing. Both produce thick succulent leaves of large size. The ground caunot be too rich for Spinach. The stronger it is, the more sucenlent will be the leaves, and, of course, the more delicate and tender. Careful weeding 
and hoeing up the earth, so as not to choke up the hearts of the plauts, are indispensable. One ounce of seed will be sufficient for a bed five feet wide and twelve feet long, or half an ounce for the same space if sown in drills.

\section{SQUASH.}

1. Early Bush, Patty Pan.

2. Early Apple Bush, Eigg.
3. Long Green Crookneck.

4. Cocoa-nut, Valparaiso. Porter.

Plant in hills, prepared in the same manuer as for Cucumbers and Melons, and cultivate in like manner. Nos. 1 and 2 are of compact growth, aud well adapted to small gardens. No. 2 is particularly so, and a very early variety. No. 4 is used both as a vegetable dish and for pies, and may be kept throughout the winter. The Bush varieties should be planted three or four feet distant, and the running sorts from six to nine, aceording to their nature. Five or six seed should be planted in each hill, to guard against accidents, and when the plants are out of danger, be thinned to two or three in a hill. The summer rarieties should be gathered before the skin gets hard. The other varieties should be permitted to ripen, and, when gathered, exposed to the sun and air, in some dry situation, before stowed away.

\section{TOMATO.}

1. Large Red.

2. Large Yellow.
3. Pear-shaped.

4. Cherry.

For early use, sow very early in the spring, in a hot-bed, and transplant when frost has ceased, in a warm border, three feet apart. The ground should be hoed often and drawn up slightly around the plants till one foot high. If the tops of the shoots be pinehed off just above the blossoms, the ripening of the fruit will be hastened. For summer use, sow as soon as frost has ceased. As the plants progress in growth, sticks or trellises should be pro- 
vided, to which the plants should be trained in such mauner as will permit each portion to receive its due proportion of the sun. The south side of a fence is an eligible situation for the early maturing of the fruit. No. 1 is the variety usually preferred, the earliest that grows to large size, and a great bearer. No. 2 is cultivated principally for preserving. No. 3 is of small size and used for pickling. No. 4 is a small, round variety, cultivated for pickling, and very early.

\section{TURNIP.}
1. Early Flat Dutch.
2. Red-topped.
6. Yellow Aberdeen,
3. Early Stone. Scotch Yellow.
4. Large Norfolk.
5. Large Globe.
7. Dale's Hybrid.
8. Ruta Baga, 'Sweedish.

The ground cannot be too rich for Turnips. Old sod, or newlycleared land, produces the largest and finest flavored sorts. The best for family use, as well as for general culture, are Nos, 1 and 2 , which resemble each other in all respects but color. They are of quick growth, with small narrow leaves, and admit of standing quite close together. They are quite distinct from, and superior to, the common White and Red-top varieties usually cultivated. For summer use, sow early in the spring, in drills twelve inches apart, and thin to five inches. They are not, however, certain to suceed at this season. For the main crop, sow at end of summer, either broadeast or in drills. The largest crops are obtained by the latter method. No. 3 is a good kind, but of slower growth than either of the former. Nos. 4, 5, and 6 are robust kinds, and are found well adapted to the South. No. 7 resembles No. 8 in some respects, but is more delicately flavored, and much esteemed for table use. No. 8 is more generally grown for stock than for table use, but is excellent late in the spring, when the other kinds have become pithy. At the North, the five last named should be sown the middle of summer, while Nos. 1 and 2 frequently yield abundant crops when sown the first of autumn. Turnips are 
affected in their form and flavor by soil, climate, and mode of culture. The sowings should always be male just before a rain, if possible, for the escape from the fly and the success of the crop depends upon quick germiuation and a rapiel growth at first. The ground should he kept free from weeds, and when the bottoms begin to enlarge, the earth should be brushed from about the roots to the deptll of half an inch. A light dressing of wood-ashes, lime, or soot, should he given morning and evening for a few days after sowing the seed, which will generally serve to protect the (rop against the attacks of the fly. To protect during winter, store in a cool, airy cellar, and cover with sand, or in mounds of dry earth. 
DESCRIPTIVE LIST

OF

\section{AROMATIC AND MEDICINAL HERBS.}

These possess a strong spicy taste and odor, and are cultivated for rarious culinary and medicinal purposes. Those marked rvith an asterisk (*) are perennials, and, when once obtained, may be preserved for many years. The seed of these should be sown the middle of spring, in seed-beds, and transplanted in the ensuing autumn or spring. The others are annuals, and come to perfection the first season. These should be sorn the middle of spring, and when the plants are up a ferw inches high, may be thimned out to proper distances. Each lind should be sorm by itself, in drills about half an inch deep and twelve inches apart. To preserve for use, (unless otherrwise directed,) they must be thoroughly dried, the foliage finely pulverized, and placed in jars, bottles, or other air-tight vessels, securely corked, and labeled.

\section{ANISE.—(PIMPINELLA ANISUM.)}

The seed of this herb possess considerable medicinal properties. They are aromatic and carminative, and yields an oil both by distillation and expression, which is much used in flatulencies. The leaves are used as a garnish and for seasoning various dishes.

\section{BALM. $*$-(MELISSA OFFICINALIS.)}

This is purely a medicinal herb, and is used in the form of $a$ tea as a grateful diluent in fevers. It should be gathered before it flowers, as it is then more odorous. It may be propagated from 
offsets. When once established, the only care required is to keep it from extending itself too profusely.

\section{BASIL, SWEET.—(OCYMUM BASILICUM.)}

Cultivated for various culinary purposes. The young leaf-tops are used in making salads and soups, their flavor resembling that of cloves. May be propagated from cuttings.

\section{BENE-PLANT.-(SESAMUM ORIENTALE.)}

The seed should be sown in a warm border, in shallow drills about one foot apart, and the plants protected against frost. A couple of leaves, when green, placed in a tumbler of water forms a thin jelly, without taste or color, which children afflicted with the summer complaint will drink freely. An invaluable plant, and the best remedy for this fatal disease. If the top of the plant be pinched off, it will throw out leaves in profusion. Cats are quite fond of it and frequently destroy it.

\section{BONESET:券-(EUPATORIUM PERFOLIATUM.)}

A medicinal plant, chiefly cultivated for its leaves, which are used in decoctions. Its medicinal properties are those of a tonic stimulant, and when given in moderate quantities are said to promote digestion and restore tone to the system.

\section{BORAGE.-(BORAGO OFFICINALIS.)}

This herb possesses sedative properties. The young leaves are used as a salad. The plant is quite ornamental, and may be propagated from suckers

\section{CATNEP.*-(NEPETA CATARIA.)}

Used medicinally in the form of a tea. Cats are very fond of it when the scent of the plant is excited by being bruised from gathering or transplanting, and frequently destroy it. When grown from seed, they will not gencrally disturb it unless from like causes. 


\section{CARATAY.-(CARUMI OARUI.)}

This is a biennial plant and is cultivated chiefly for its seed. They are used for flavoring cakes, de., and form a carminative distilled water. The leaves are used as an ingredient in salads. The roots are said to be superior in flavor to those of the Parsnip. May be propagated from suckers.

\section{CHANOMILE.:-(ANTHEMIS NOBLIS.)}

This is a medicinal plant of great utility. The flowers should be gathered before they begin to fade, and when they are perfectly free from moisture. Spread in a shady place to dry, and place in paper bags. This herb delights in a poor, sandy soil, and may be readily propagated by divisions of the root.

\section{CORIANDER.-(CORIANDRUM SATIVUM.)}

The leaves of this plant are strongly scented. The seed, which are slightly aromatic, are used medicinally, in culinary purposes as a sweatmeat, and for seasoning various drinks. May be propagated from suckers.

\section{DILL.*-(ANETHUM GRAVEOLENS.)}

The seed of this plant are used in medicine as carminatives. The leaves are used in soups, \&c. When once established, an abundance of young plants may be had every spring. May be propagated from cuttings and suckers.

\section{ELECAMPANE.*-(INULA HELENIUM.)}

This is purely a medicinal plant, and is cultivated for its roots, which, when dried and made into a tea, is an excellent remedy for colds. A moist and shady position is essential to its culture. Mray be propagated by dividing the roots. 


\section{FENNEL, COMMON.*-(ANETHUM FENICULUM.)}

The leaves of this plant are used in salads and sauce for fish. When not required to produce seed, the stalks should be cut down, from time to time, during the growing season. By this method, the roots will last many years May be propagated from suckers and offsets.

\section{FEVERFEW."*-(CHRYSANTHEMUM PARTHENIUM.)}

This plant is cultivated for medicinal purposes. The roots have a strong unpleasant smell and a bitter taste. Used externally in the form of lotion and of poultice, and internally as an infusion for cholic, hysterical affections, and weak digestion. May be propagated by dividing the roots.

\section{GINGER.*-(ZINIBER OFFICINALE.)}

The roots of this plant are much used both in medicine and domestic cookery. The roots should be planted in a hot-bed, and, when frost has ceased, transplanted to two feet distant from each other, and the ground kept clean and free from weeds. The roots desired for use should be taken up when the stallis fidde, and, being first washed and scalded, dried in the sum. Those intended for planting, should be taken up somewhat earlier, and protected from frost. In the middle or southern States, it may readily be propagated by dividing the green roots. In the South, and perhaps in some of the middle States, they may be permitted to remain in the ground till spring, by corering the roots with straw or long manure.

\section{HOREHOUND.*-(MARRUBIUM VULGARE.)}

This is purely a medicinal herb, and has an aromatic odor when dried, which it soon looses if not excluded from the air. It is tonic, diuretic, and laxative, and a popular domestic remely for 
conghs. When once established, a plentiful supply of young flints may be had every spring from the seed which drop.

HYSSOP.*-( IIYSSOPUS OFFICINALIS.)

A neat little evergreen and quite fragrant when in flower. The whole plant has a strong aromatic scent, and the leaves and flowers a strong pungent taste. The flower-spikes and young leaves are used for medicinal purposes. The flower-stems, when gathered and dried, should be hung up, in some dry situation. Lusily propagated by dividing the root.

\section{LAVENDER.*-(LAVENDULA SPICA.)}

The flowers should be cut in dry weather, when they begin to How, close to the stem. The uses of which are well known, whether used in the flower or the water which is distilled from it. When grown in poor and gravelly soils, the flowers have a powerful odor, while in rich soil, they grow more luxuriantly, but have less perfume. Lasily propagated from cuttings or divisions of the roots.

\section{MARIGOLD, POT.—(CALENDETA OFFICINATIS.)}

Both the leaves and flowers of this plant are used for flaroring rarious dishes in domestic cookery. When the flowers are full blown, they, as well as the leaves, should be gathered, dried, and preserved for future use.

\section{MARJORAM, SWEET.-(ORIGANUM MaJORANA.)}

Different portions of this plant are used for various purposes. The seed and leaves are used medieinally, and the top for dyeing. The young tops and leaves are used in soups, broths, and stuffings. The thied leaves furnish an excellent substitute for tea, and is said to be exceeclingly grateful. Should be eut before it comes into hoom, hung up in swall bunches to dry, first for a day in the sun, and then in the shade, and when quite dry, hung up in paper bags 
in a dry place. It thrives well in a light, dry, and moderately fertile soil, and should have an open situation.

MINT, SPEAR.*-(MENTHA VIRIDIS.)

This hert contains much essential oil, and which is used for various purposes. The essential oil, a conserve, a simple water, and a spirit, are the officinal preparations from this plant. The conserve is very grateful, and the distilled waters, both simple and spirituous, are generally thought pleasinnt. The leaves and tops are likewise used for various culinary purposes. For medicinal use, it should be eut in dry weather, just before the flowers ap)pear. Should be transplanted every third year, and requires a moist shady position. Propagated by dividing the roots.

\section{MINT, PEPPER.*-(MENTHA PIPERITA.)}

This plant has a much stronger smell and a more penetrating taste than Spearmint. The officinal preparations are an essential oil, a simple water, and a spirit. To keep up its (quality, the roots should be transplanted every third year, otherwise it degenerates into the flavor of Spearmint. When eut in wet weather, it turns black, and is worth but little. Propagated by dividing the roots.

\section{PENNYROYAL.*-(MENTHA PULEGIUM.)}

A medicinal herb, but used for some few culinary purposes. The plint has an odor somewhat like Speamint, but less fragrant. The taste is aromatic and pungent, with a slight flavor of camphor. Formerly in high repute, but now seldom used in regulin practice. Propagated by dividing the roots.

\section{ROSEMARY.*-(ROSMARINUS OFFICINALIS.)}

By distillation, this plint yiekls a light-pale essential oil of great fragranee, which is imparted to rectified spirit. It is the principal ingredient in Humgary water. Tea is mate from the leares for headache and nervous perons. It delights in a lean, dry soil, 


\section{AND VEGETABLF-GRDEN MINTAT.}

and, when once established, will list for many years. Propragated from cuttings, in spring and autumn.

RUE, COMMON.*-(RUTA GRAVEOLENS.)

The leaves of this plant have a powerful unpleasint odor, and a hot, bitter, nauseous taste. When green, they will inflame and blister the shin, but looses this property in drying. Medienally, it is stimulant and antispasmodic. Propagated from curtings, in spring and autumn.

\section{SAGE; GARDEN:\%(sALVLA ofFicinalis.)}

Used for various culinary purposes, and in some cases medicinally. It was formerly in great repute in medicine. Wet ground is not congenial to its growth. May be propagated from seed, cuttings, or divisions of the root. The shoots of the present year should be employed for cuttings, as they root freely, and if moderately watered till rooted, will form strong plauts the first season. As soon as the foliage has matured, Sage should be cut to within two eyes of the present year's growth, dried in the shade, placel in paper bags, and hung up in a dry situation. By this method, a second crop may be obtained.

\section{SAYORY.}

There are two varieties of this plant cultivated for various culinary, and some medicinal purposes. Winter Savory (saturesa montaxa) is a perennial plant, and may be propagated from seed, cuttings, or offsets, the middle of spring. Summer Savory (SATUREJA HoRTexsis) is an annual, and should be planted every year if wanted in perfection. Both varieties are much esteemed for their warm, aromatic, and pungent leaves. Should be cut and dried as directed for Sage.

\section{TANSY.*-(TANACETUM VULGARE.)}

The common Tansy has a strong aromatic smell and a bitter taste. It is stimulant and carminative, and a clistilled water and 
a stomachic bitter are prepared from it. The young leaves are shredded down and employed to give color and flavor to puddings. They are also used in omelets and cakes. Propragated from seed and divisions of the roots.

\section{THYME.**-(THYMUS VULGARIS.)}

The young leaves of this plant are employed for various culinary purposes. It yields a species of camphor in distillation with water. Propagated from seed or divisions of the roots.

\section{WORMIWOOD.*-(ARTEMISIA ABSINTHIUM.)}

This is purely a medicinal plant, and used for various purposes. It is said to be a stomachic and slightly stimulating. Propargated from seed, cuttings, and divisions of the roots. 


\title{
GENERAL INDEX.
}

\author{
FL OWER-GARDEN.
}

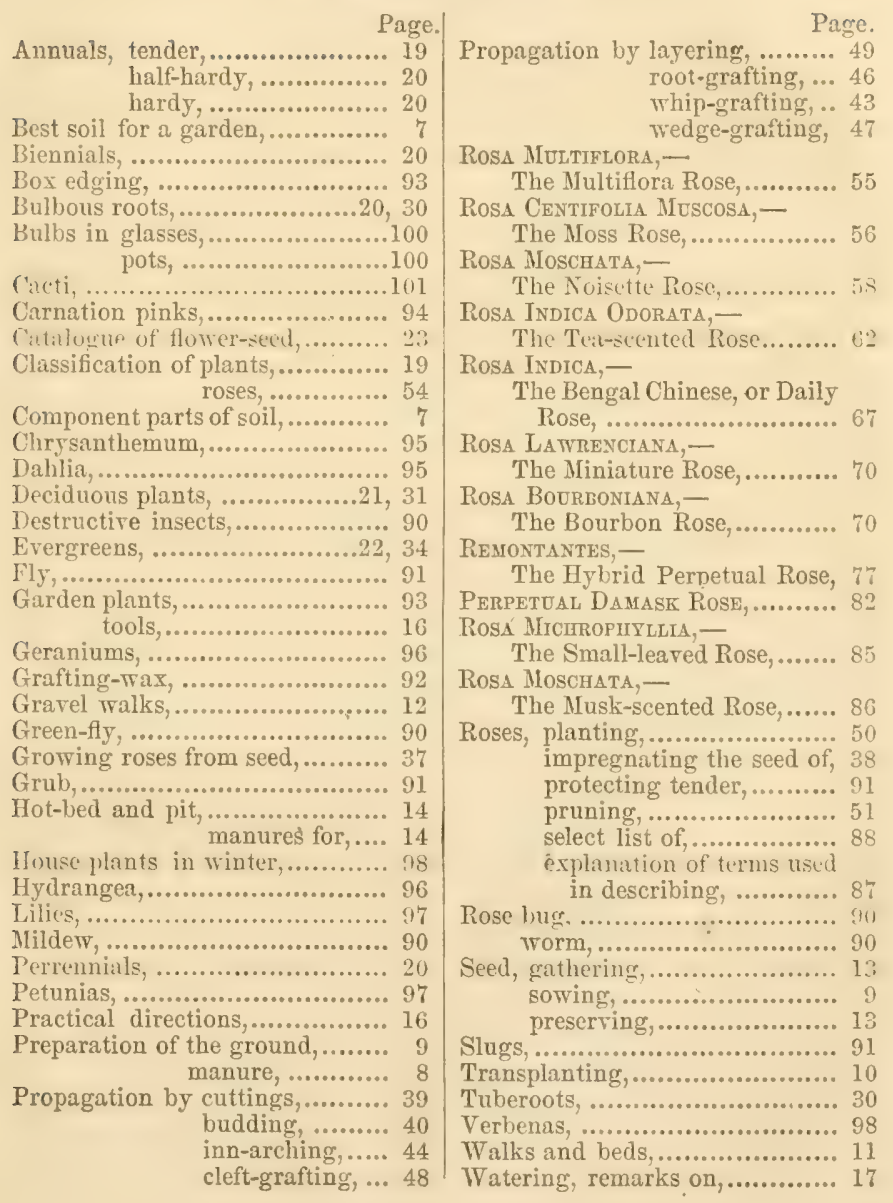




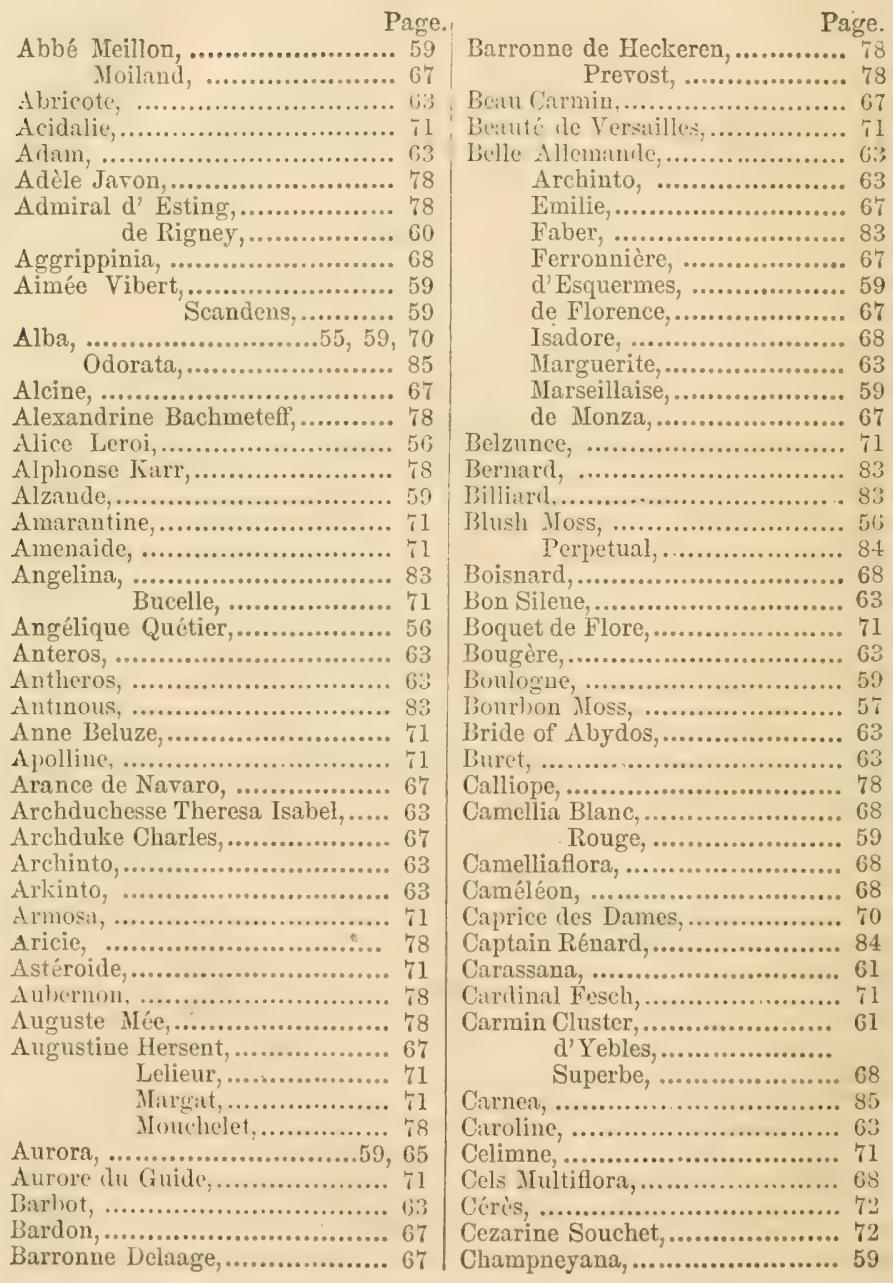




\begin{tabular}{|c|c|}
\hline Page. & D'Esounermes \\
\hline Champney's Pink Cluster,......... 59 & D'Esquermes, ....... \\
\hline rlemagne, ....................... 72 & De la Flieche, ......... \\
\hline Clatries Martel, ...................... is & Delille, ............... \\
\hline oaud,,$\ldots \ldots \ldots \ldots \ldots \ldots .6$ & Delphine Gaudot... \\
\hline 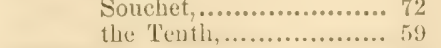 & $\begin{array}{l}\text { De Ileaux,............ } \\
\text { De Mlontmorency... }\end{array}$ \\
\hline Clantenay, ......................... 访 & $\begin{array}{l}\text { De Montmorency,... } \\
\text { Desdemona,........... }\end{array}$ \\
\hline 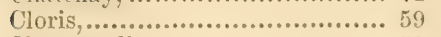 & Destraches, .............. \\
\hline matelle,......................... & Désiré Roussell,... \\
\hline inf....................... & Desprez d' \\
\hline 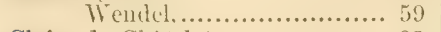 & De \\
\hline lâtelet,,...$\ldots \ldots \ldots \ldots \ldots$...... & niensis, ......... \\
\hline l,,$\ldots \ldots \ldots \ldots \ldots \ldots$ & Docteur Blandin,... \\
\hline $\begin{array}{l}\text { Seringe } \\
\text { lifton Moss, }\end{array}$ & $\mathrm{Ha}$ \\
\hline 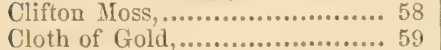 & Marjolin, . \\
\hline 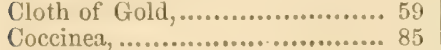 & $\operatorname{Mar} x, \ldots . .$. \\
\hline 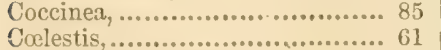 & Roques, . \\
\hline tis, ................................. & Carlos, \\
\hline relle,,$\ldots . . . . . . . . . . . . .$. & Strind Aloso \\
\hline Marne,........................... & ble White Striped Mloss,.... \\
\hline rne & mont, ................ \\
\hline 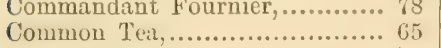 & Duc de Alençon, ,....... \\
\hline tt, ..................... & $\begin{array}{l}\text { ale, .... } \\
\text { tres. }\end{array}$ \\
\hline nt,....................... 7 & $\begin{array}{l}\text { Chartre } \\
\text { Isly,.... }\end{array}$ \\
\hline alivet, ............... 79 & Duchess de Galliera,.. \\
\hline$n d, \ldots \ldots \ldots \ldots \ldots, 64$ & .............. \\
\hline .........664, 79 & \\
\hline & $r, \ldots \ldots \ldots$ \\
\hline Comtesse Duchatel,................ 79 & Normandie,.......... \\
\hline ….......... 5 & , n............ \\
\hline & 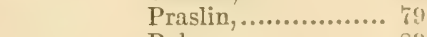 \\
\hline .............6 6 & $\mathrm{R}$ \\
\hline & $d, \ldots \ldots \ldots \ldots$ \\
\hline iteau, .......... t & ............. \\
\hline & ….......6. 60 \\
\hline us,,$\ldots \ldots \ldots \ldots \ldots \ldots$ & set, ................. \\
\hline on..................... & ............... \\
\hline Cornet,.................................. & (............... \\
\hline onne de Beranger,............. & Talbot, \\
\hline Cramoisie,.. & Eclatante, . \\
\hline & Edouard Desfosés, ............. \\
\hline $\begin{aligned} \text { rested Mos } & \text { Pro }\end{aligned}$ & Eliza Balcombe,..... \\
\hline Crimson, . & Emilie Courtier, ......................... \\
\hline lobe $, \ldots \ldots \ldots \ldots \ldots \ldots \ldots \ldots, 7$ & Etna,......................... 57, \\
\hline Ladame Desprez,....... 73 & rer,$\ldots \ldots \ldots \ldots \ldots \ldots$ \\
\hline ................. 5 & harnais, .............. \\
\hline n.............. & \\
\hline Superbe, .................... & \\
\hline 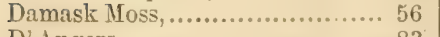 & $\operatorname{lrg}, \ldots \ldots \ldots \ldots \ldots \ldots$ \\
\hline , & Desgachez,................. \\
\hline
\end{tabular}




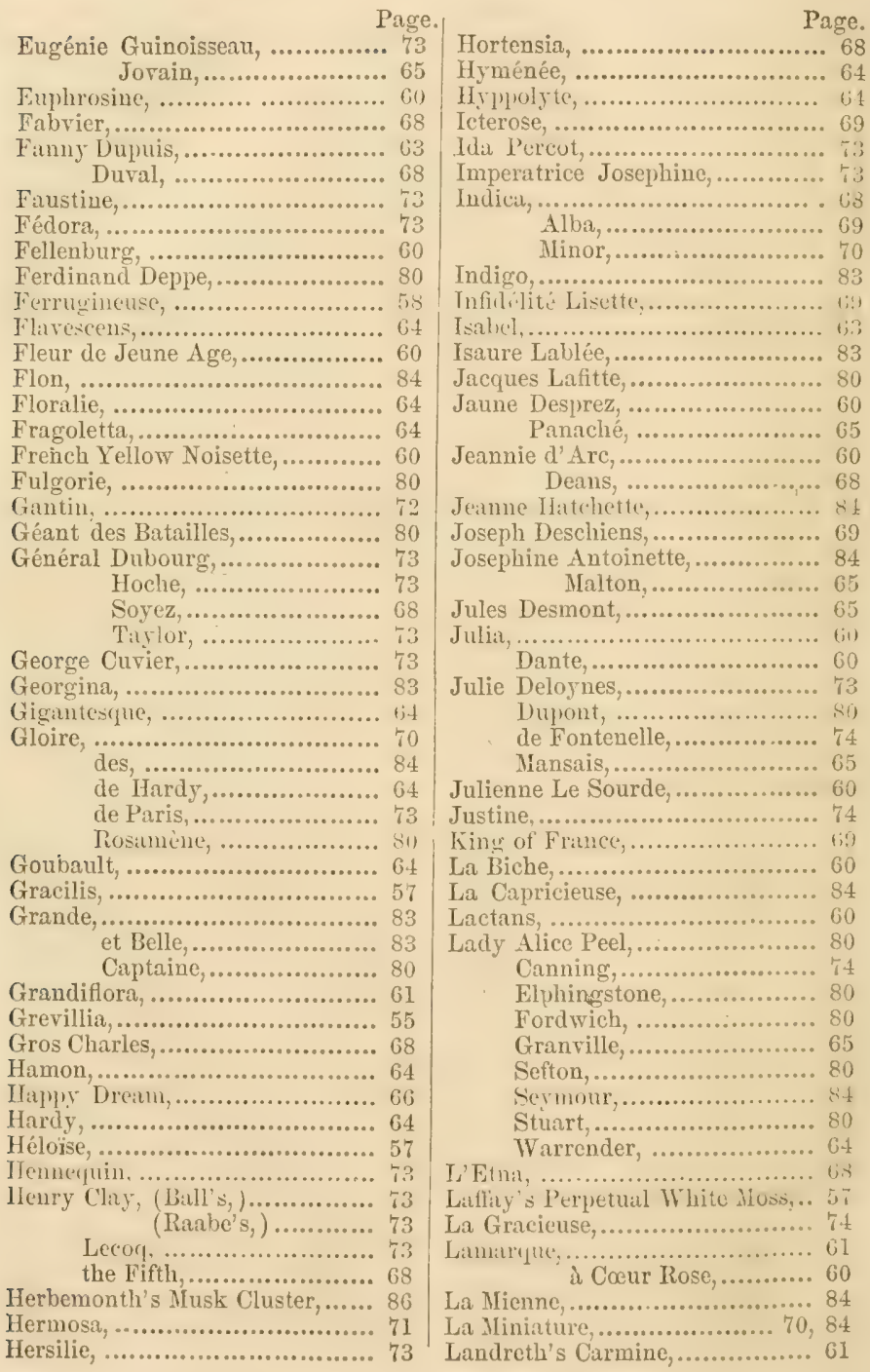




\begin{tabular}{|c|c|}
\hline \\
\hline נane,................................ 80 & 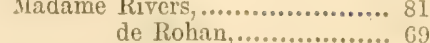 \\
\hline a Pactole, ......................... 61 & Roussell, .................6 6 \\
\hline 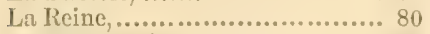 & de St. Joseph, \\
\hline i licnemmmer...................... iti & Sonchet, ........ \\
\hline Ln Renoncule,..................... 80 & Tripet, ............ \\
\hline W Sylphide,......................... 65 & Verdier,,$\ldots \ldots \ldots \ldots$ \\
\hline atifolia, .......................... 74 & Mademoiselle Rachel,.............. \\
\hline Laura, Daroust, ..................... 55 & Magnolia Rose, ........................ \\
\hline 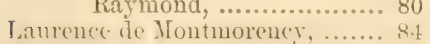 & 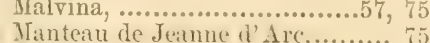 \\
\hline La Victorieuse, ....................... 62 & Maréchal de Villars, ................ \\
\hline Lavinie d'Ost, ,....................... 74 & Mlargat Jeune, ...................... \\
\hline cee,$\ldots \ldots \ldots \ldots \ldots . . . . .$. & 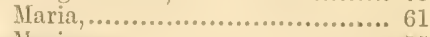 \\
\hline e: Cannie, ......... & Marianne, ........................ \\
\hline eur,$\ldots \ldots \ldots \ldots$ & 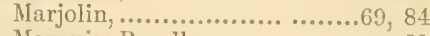 \\
\hline Leonidas, .......... & Marquise Bocella, .................. \\
\hline Le Florifère,....... & d'ITr" \\
\hline Le Grenadier,....................... 74 & Mathilde Jourdeuil, ................. \\
\hline Le Phcenix, ......................... 74 & Mauget, .............................. \\
\hline Le Similor, ........................ 62 & Melanie Cornu,................ \\
\hline Leveson Gower, ...................... 74 & Meillez, ........................... \\
\hline Lichars, ............................ 74 & Melville, .... \\
\hline 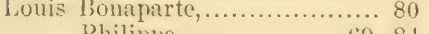 & Minerra,...$\ldots \ldots \ldots \ldots \ldots \ldots \ldots \ldots$ \\
\hline Philiple, ................69, & Minor,,$\ldots \ldots \ldots \ldots \ldots \ldots \ldots \ldots \ldots \ldots$ \\
\hline ise Colet, ........................ & Mirabile, $\ldots \ldots \ldots \ldots \ldots \ldots \ldots \ldots$ \\
\hline 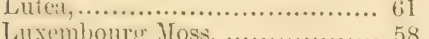 & Miss Fanus, $\ldots \ldots \ldots \ldots \ldots \ldots \ldots \ldots$ \\
\hline 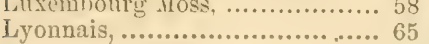 & Nomedor 24 \\
\hline adame Angelina, ................. 74 & 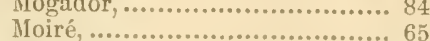 \\
\hline Aurl....................... Tit & 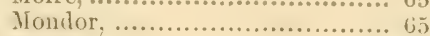 \\
\hline Beluze,................. 71 & Montrosa, .......................... \\
\hline Bréon, .................... 69 & Moss Crestata, ........................ \\
\hline Burea, .................... 69 & Mrs. Bosanquet, ................... \\
\hline Byrne, ................... 61 & Elliott,,$\ldots \ldots \ldots \ldots \ldots \ldots \ldots \ldots \ldots$ \\
\hline Cousin, .................. 74 & Siddons, ........................ \\
\hline de Crequi,...............6 6 & Wood,.................................... \\
\hline ime,$\ldots \ldots \ldots \ldots \ldots \ldots . . .6$ & Mutabilis, ......................... \\
\hline ches, ............... 81 & Multiflora, . \\
\hline $2, \ldots \ldots \ldots \ldots \ldots 65,74$ & $e_{,}, \ldots \ldots \ldots \ldots . . . .$. \\
\hline$\ldots \ldots \ldots \ldots \ldots \ldots \ldots+\ldots$ & $\ldots \ldots \ldots \ldots \ldots \ldots$ \\
\hline 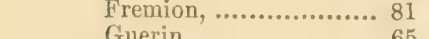 & 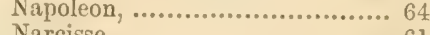 \\
\hline n.................. & ........................... \\
\hline ein & 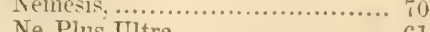 \\
\hline nbein, ................. & Ne Plus Ultra, ......................... \\
\hline till, & 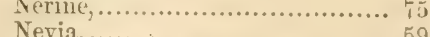 \\
\hline $\begin{array}{l}\text { Lacharme, .................. } \\
\text { Laffay, ................... }\end{array}$ & 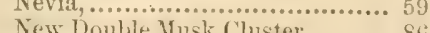 \\
\hline $\begin{array}{l}\text { Laffiy, }, \ldots \ldots \ldots \ldots \ldots \ldots \ldots \\
\text { Manoël }, . . . . . . . . . . . . . . . . . .\end{array}$ & New Jouhle Musk C Tuster,....... \\
\hline 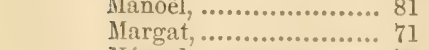 & te Cluster Moss, .......... \\
\hline …....... 7 & 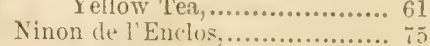 \\
\hline & 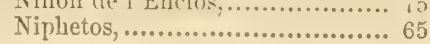 \\
\hline
\end{tabular}




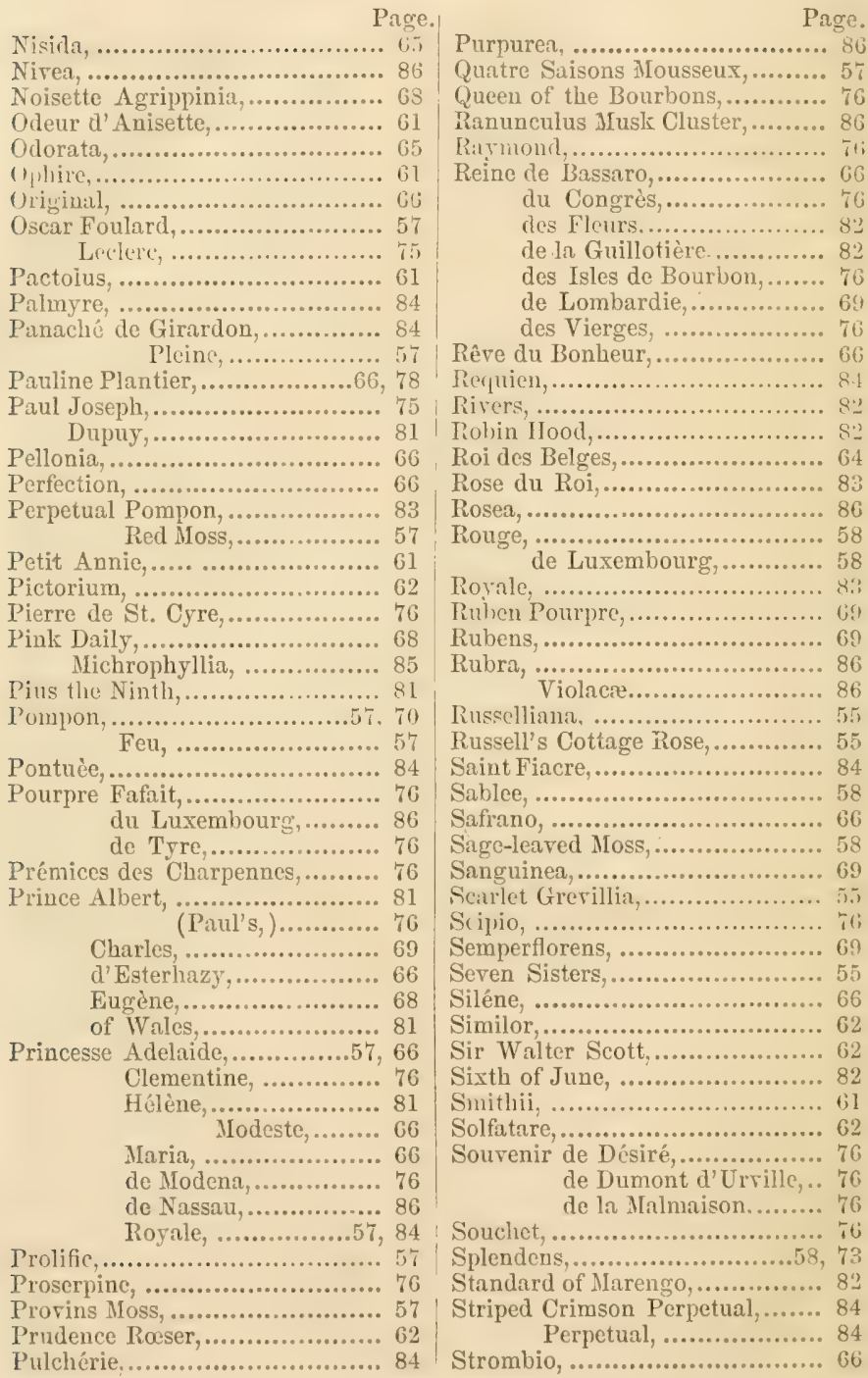




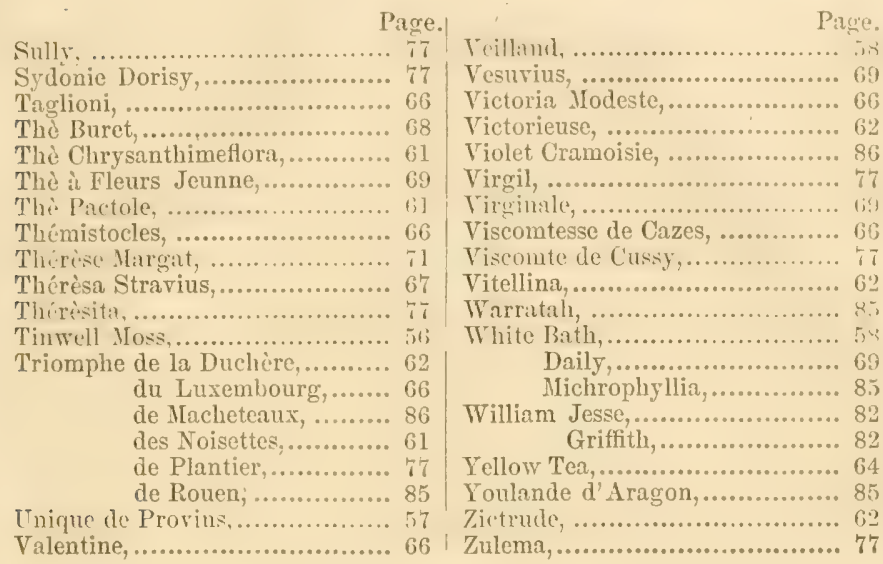

VEGETABLE-GARDEN .

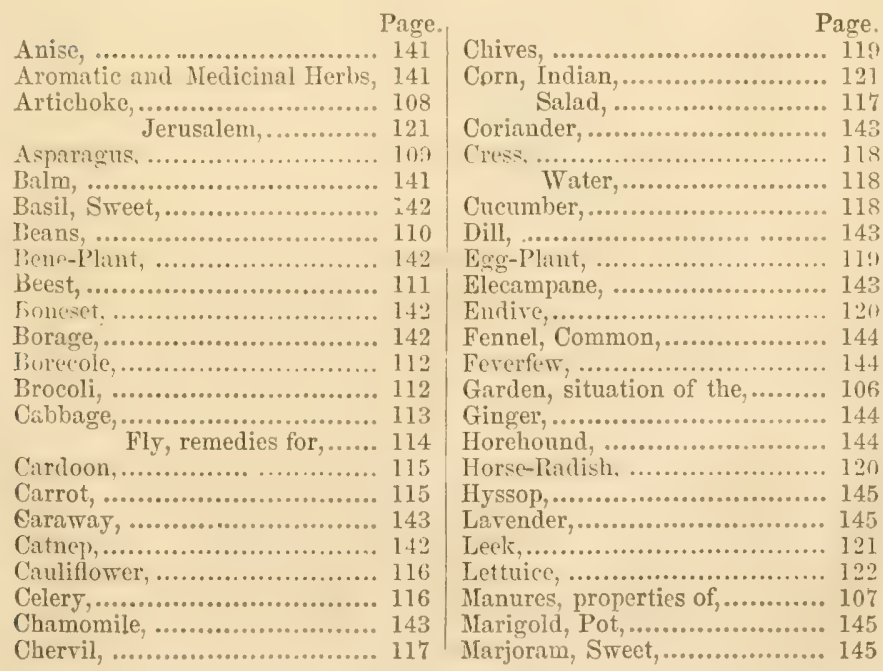




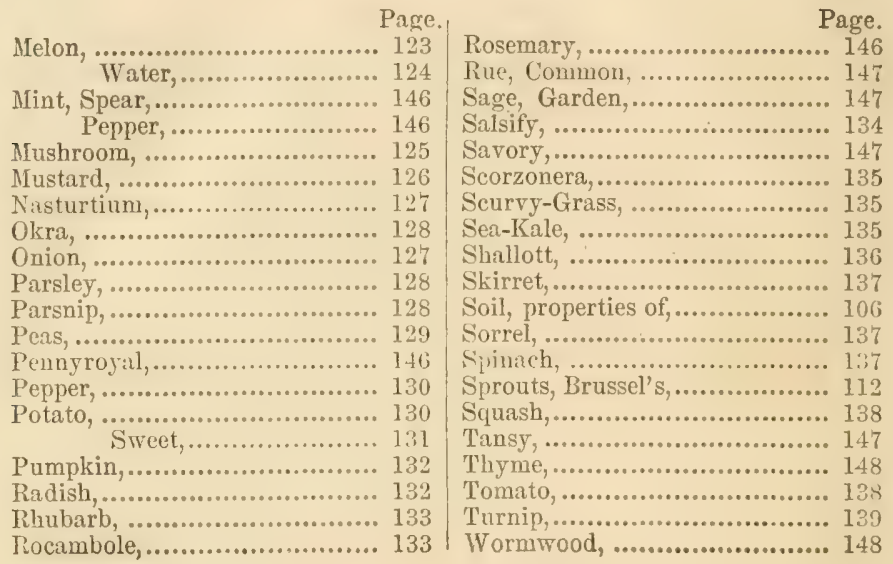













\section{y ge}

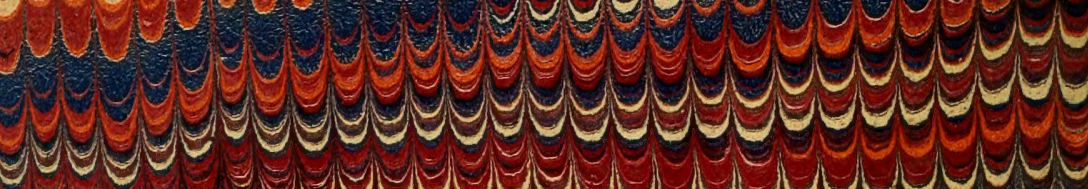
y

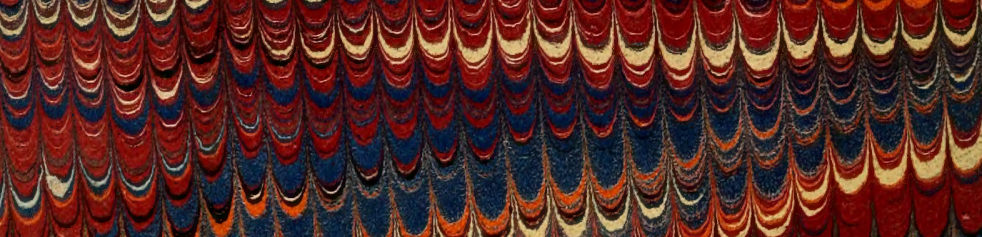
se

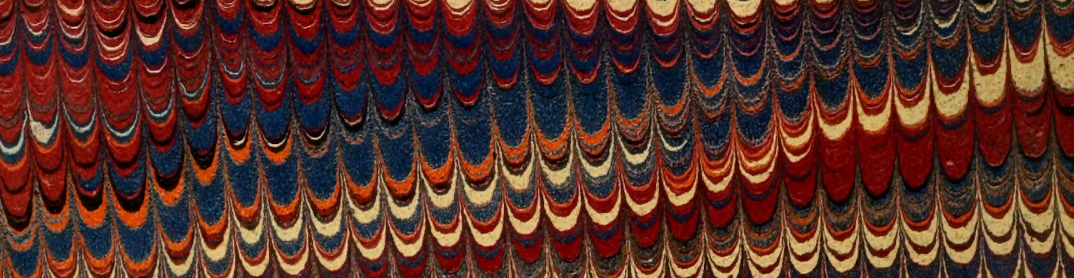

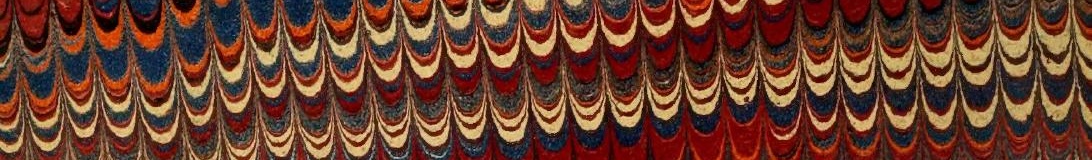
y y y y y y ygy gy Q

y y y y y y y y y y y y y

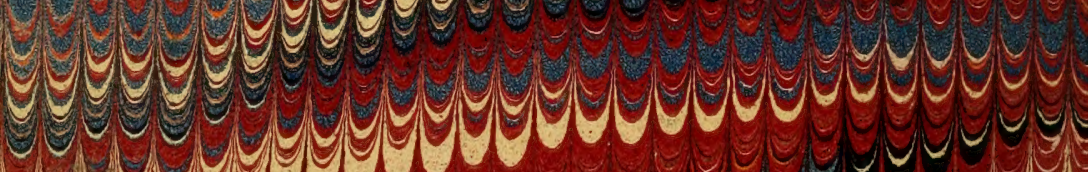



